\title{
العشوائيات ونمو معدلات الامية والتسرب الدراسى دراسة ميدانية في منطقة عشوائية بمدينة سوهاج
}

العشوائيات ونـمو معدلات الامية والتنسرب الدراستى دراسة ميدانبية في

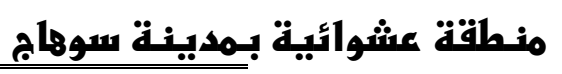

د. نهى مصطفى كمال أبو كريشة (")

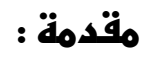

تناول البحث قضايا ثلاث تمثل ابرز ثلاث مشكلات تهدد كافة الجهود الرامية

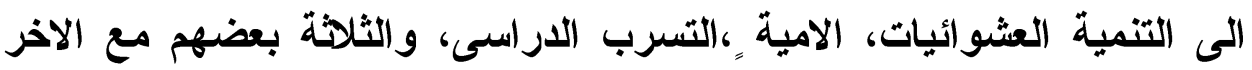

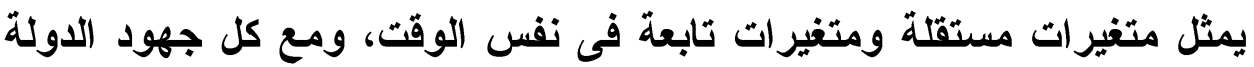

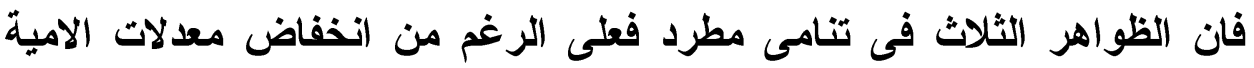

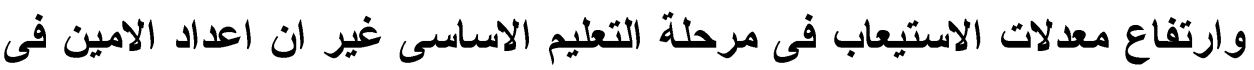

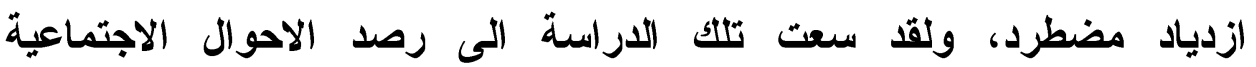

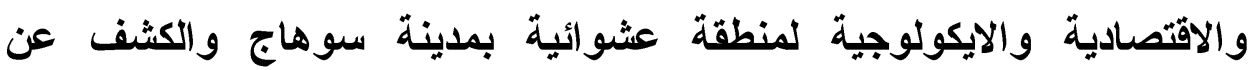

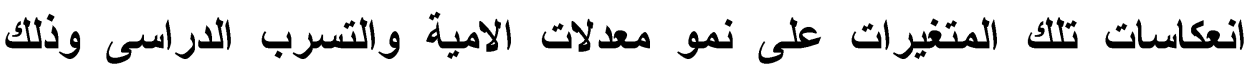

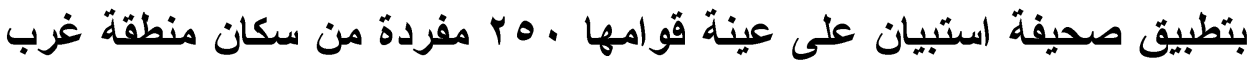

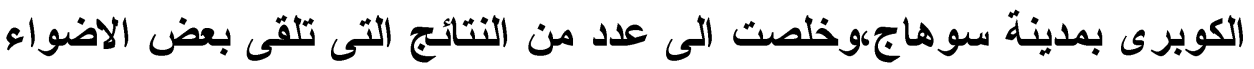

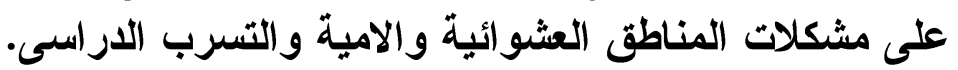

\section{1اطار النـأرى \\ العشوائيات}

فقد أصبحت قضية من أخطر القضايا التي تواجه المجتمع وخاصة في الآونة

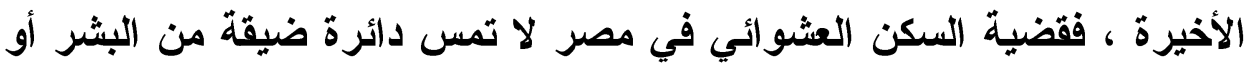

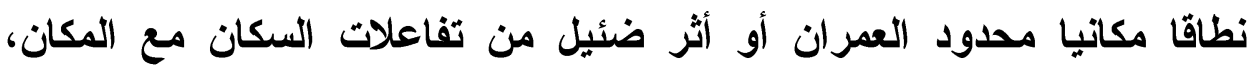
و إنما هي قضية مجتمع بأسره وخصوصاً عندما تتجاوز تأثير اته نطاقها تهان المكاني

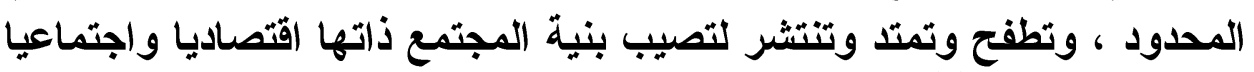

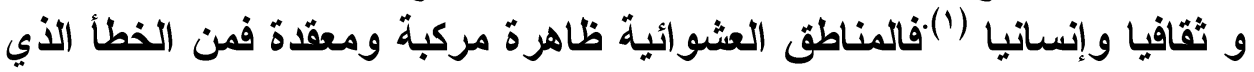
يرتكب أحيانا على المستوى العلمي أن ترى من خلا بل بعد واحد بذاته مهما بلغت أهمية ذلك البعد.

$$
\begin{aligned}
& \text { (") باحثة حاصلة على درجة الدكتوراه في علم الاجتماع، كلبة الاداب، جامعة سوهاج. }
\end{aligned}
$$

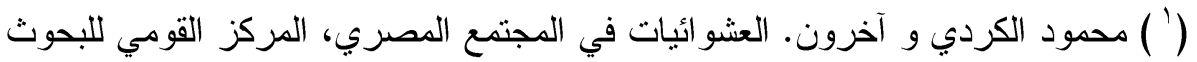

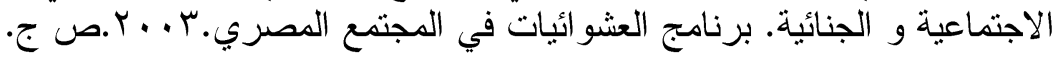

$$
\begin{aligned}
& \varepsilon .0
\end{aligned}
$$




\section{المناطوة العشوائية.}

1-1المناطوة المتنفلهة:

يربط التعريف العمرانى بين مفهوم التدهور العمرانى و المناطق السكنية المتردية و العشوائية بشكل مباشر و بالتالى يمكن القول أن توصيف التدهور العمرانى من هذا المنطلق إنما ينطبق أيضا على العشوائيات مثئه فئه في ذلتك مثل

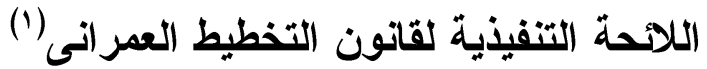
هذا و قد عرفها "محمود الكردي " بأنها ذلك التجمع السكاني الأي نشأ في غيبة التهية

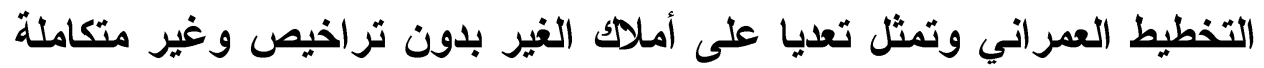

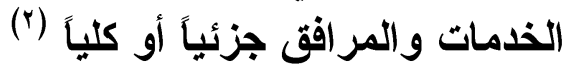

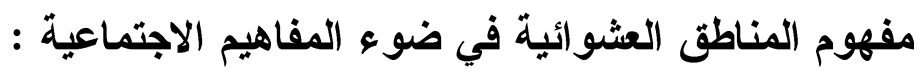

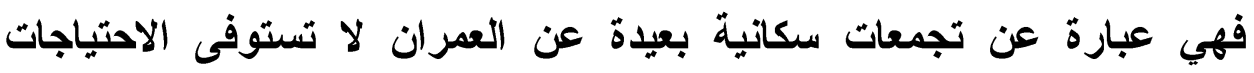

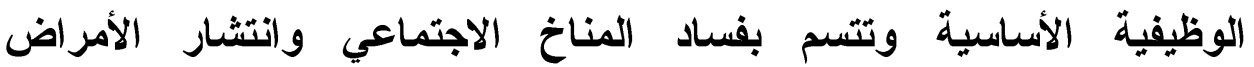

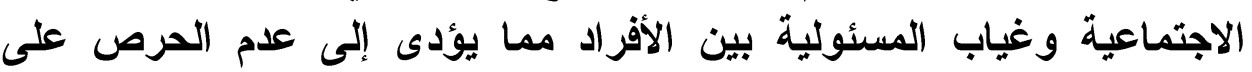

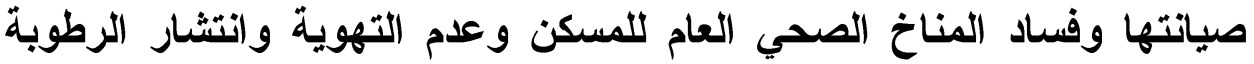

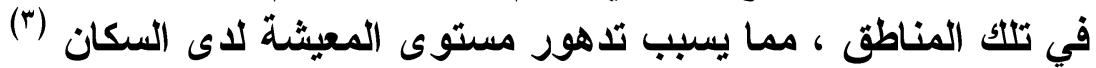

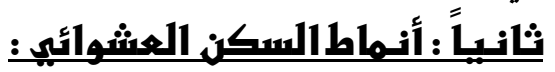

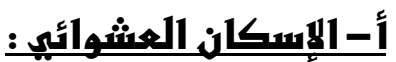
هو سكن تم بناؤه بطريقة جيدة داخل الحدود الإدارية للمدينة لكن بلون

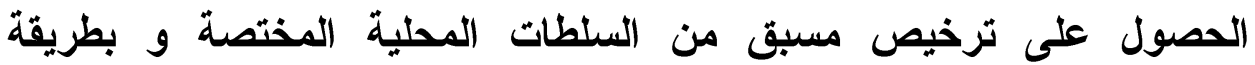

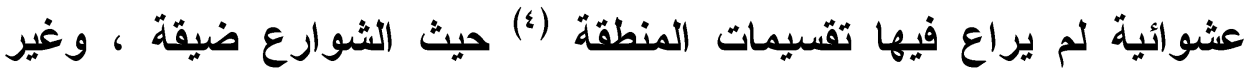

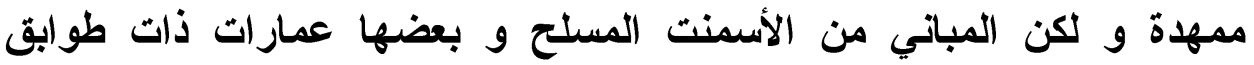
متعددة و تلخلها المرافق بالتدريج و لأي فئن إيجار اتها مرتفعة و بعضها

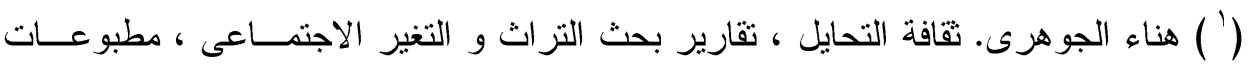

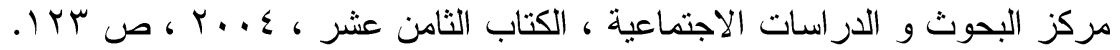

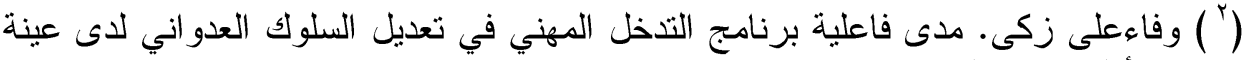

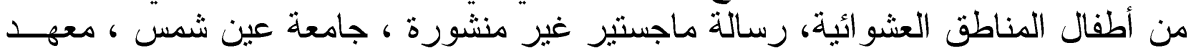

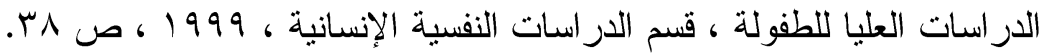

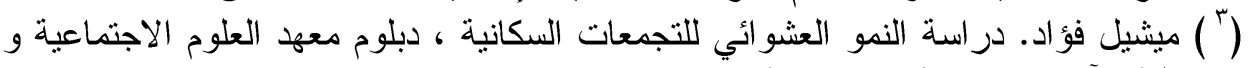

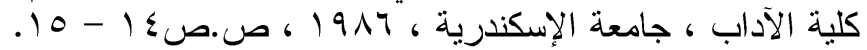

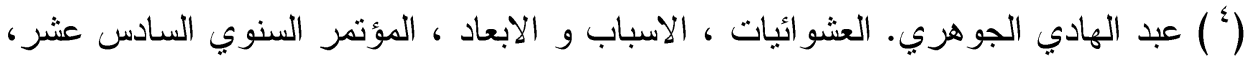

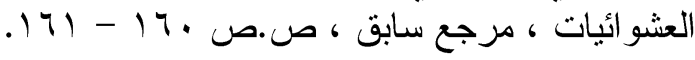




\section{العشوائيات ونمو معدلات الامية والتسرب الدراسى دراسة ميدانية في منطقة عشوائية بمدينة سوهاج}

بالتمليك ، و هي تمثل الحل الثعبي لمشكلة الإسكان بعد إخفاق الحل

(الحكومي (')

\section{ب - السككن المشوه (إسكان العششر و الأكواف ) :}

و هو كل ما بنى بمواد غير ثابتة أو شبه ثابتة كالصفيح و الأخشاب و بطريقة التشئة

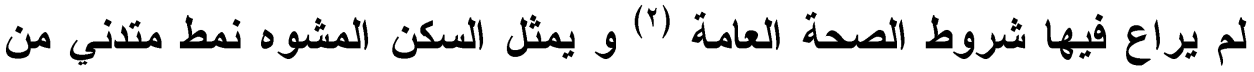

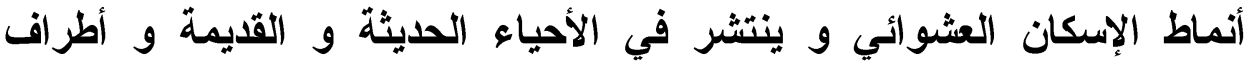

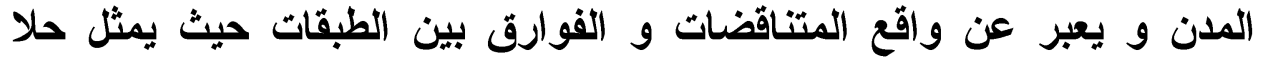

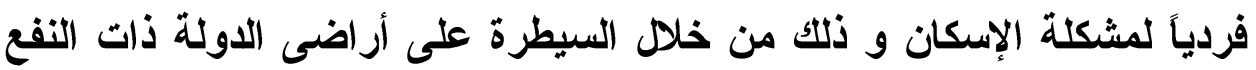

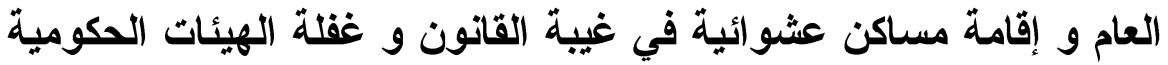

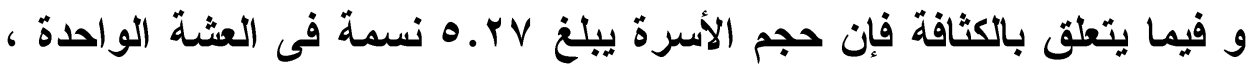

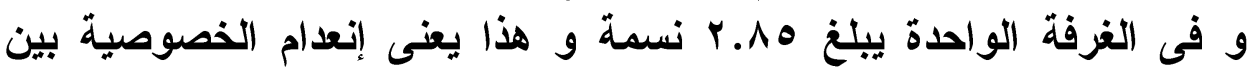
أفر اد الأسرة المقيمين فيها. جهو أحد أنماط الإسكان العشوائي المقنن حيث يأخذ صفة الرسمية ، وذلك لأن

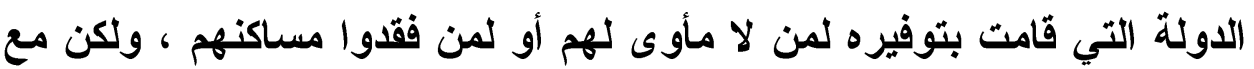

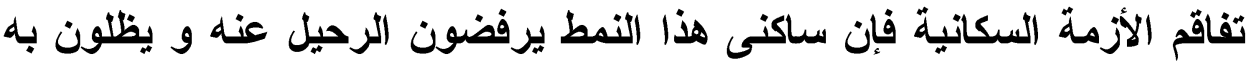

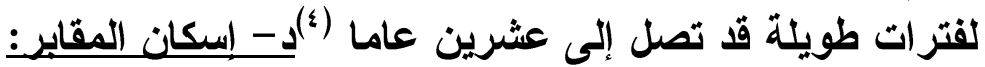

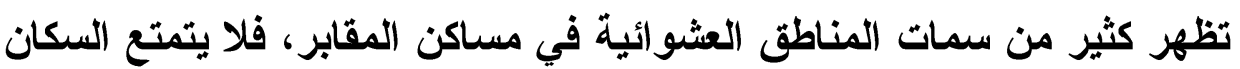

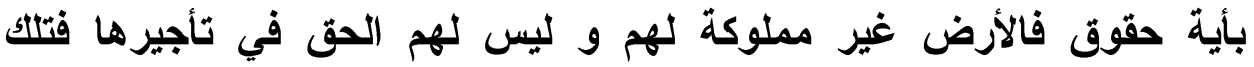

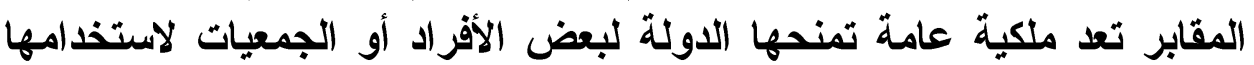

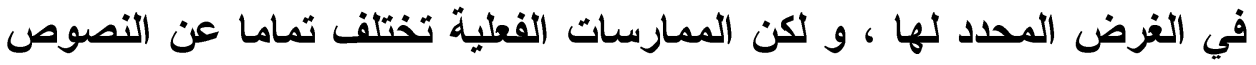

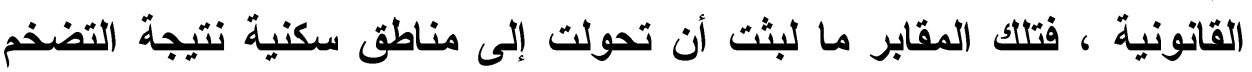

(' ) مددوح الولي. سكان العشش و العشوائيات ، الخريطة الإسكانية للمحافظات ، مطابع

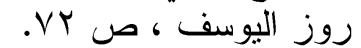

( ( ) بدرية شوقى. البيئة الاقتصادية و الاجتماعية لسكان المناطق العشوائية ، مرجع سابق ،

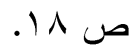

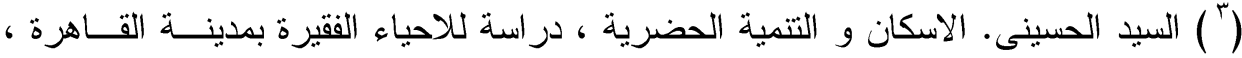

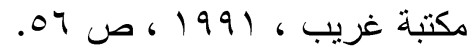
(" ) محمود الضمر انى. حجم الاسرة و الثره على على التتشئة الاجتماعية. حجم الأســرة و أثــره

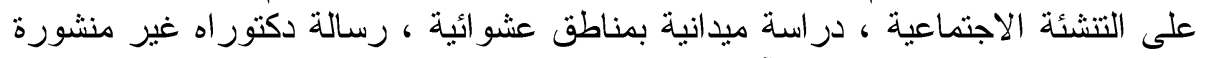

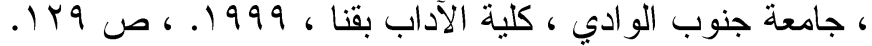


الحضري و في غيبة الجهات المعنية تحولت إلى مناطق سكنية تفرض إيجارات

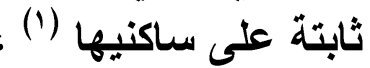

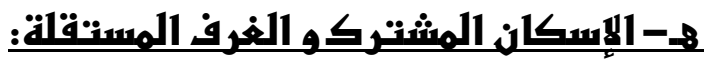
و هو يطلق على سكن عائلي في غرفة واحدة أو أكثر من أسرة في مسكن

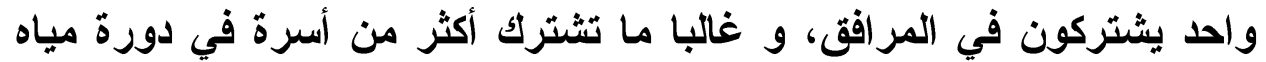

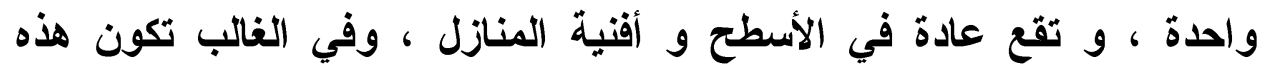

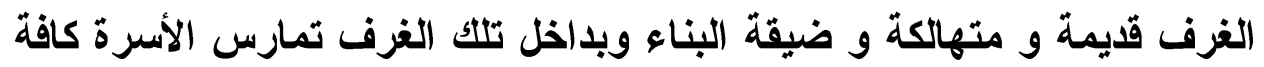

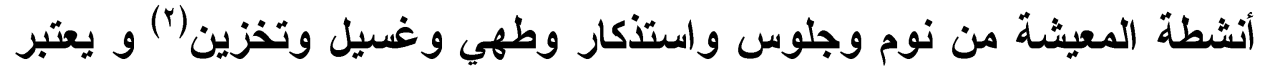

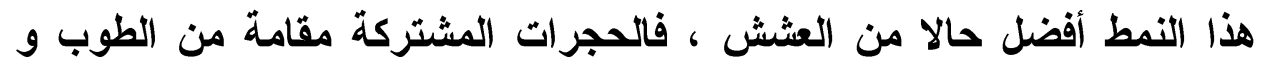

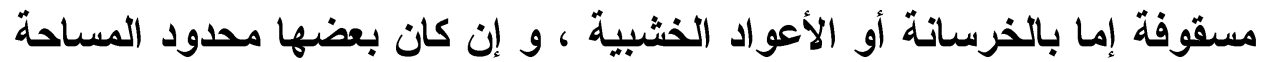

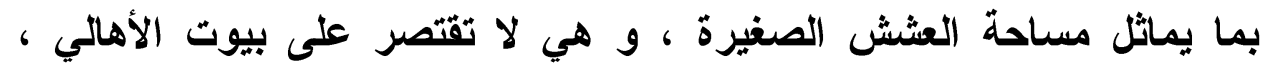

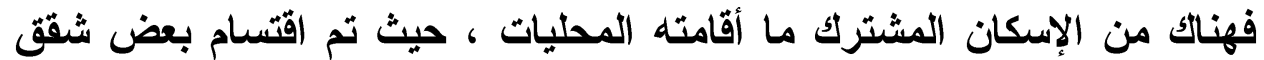

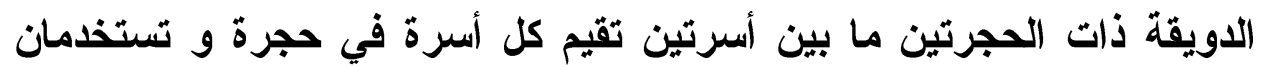

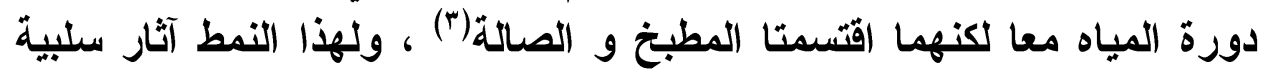
علي المقيمين بها ، حيث تؤدي الحياة فيها إلى العديد من الآثار النفسية التهاية

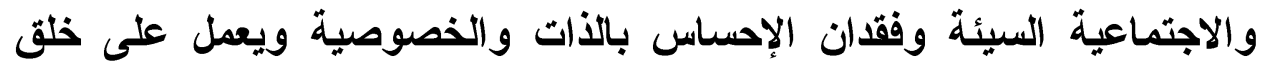

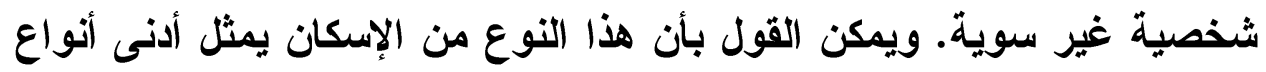

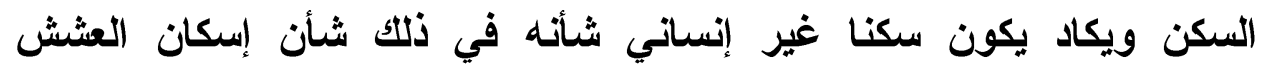

والصفيح.

ثنانيا : العوامل و الأسباب التي أدت إلى ظهور المناطة العشوائية: لقد تعددت الاتجاهات التى تحدد أسباب نشأة المناطق العثوائية و و عوامل نموها و تكوينها في مصر، و إن كان بشكل عام هناتك شبه اتفاق حول طبيعة

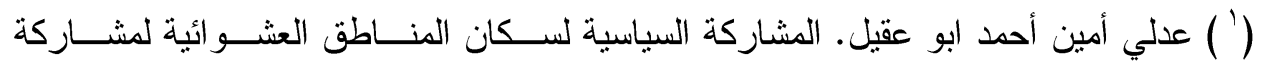

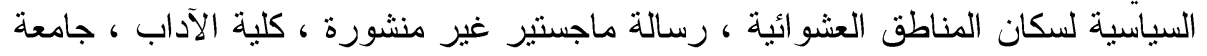

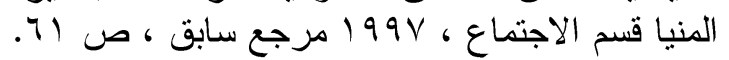

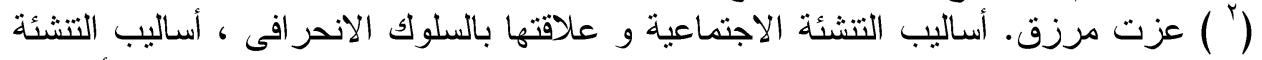

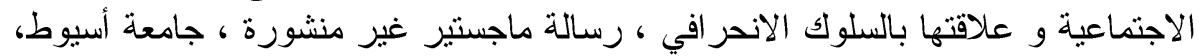

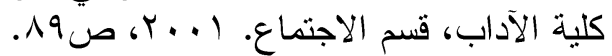
(" ) ممدوح الولي. سكان العشش و العشو العائيات ، الخريطة الإسكانية للدحافظات، مرجع سابق

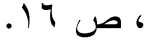




\section{العشوائيات ونمو معدلات الامية والتسرب الدراسى دراسة ميدانية في منطقة عشوائية بمدينة سوهاج}

هذه العوامل و الأسباب حيث أكلت معظم الدراسات على أن سبب ظهور

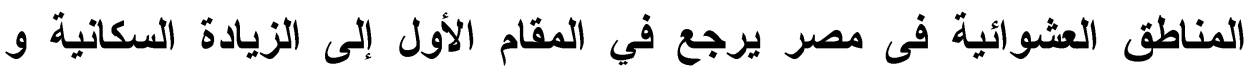

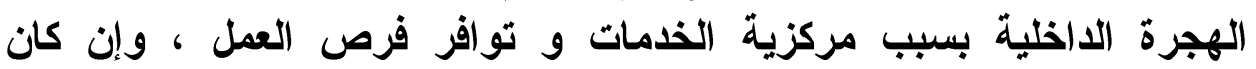

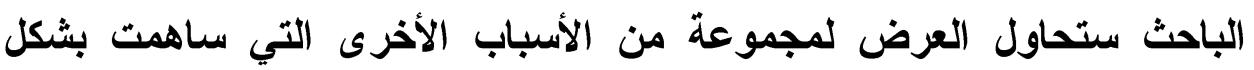
فعال في نمو تلثك المستوطنات العرضي 1- الأسباب الإتنما عية:

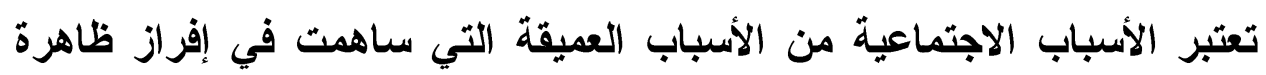

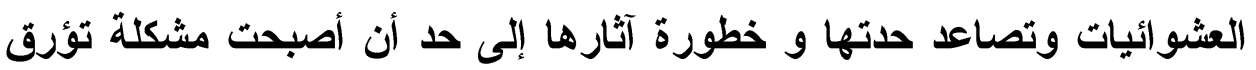

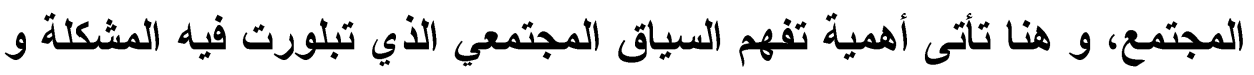

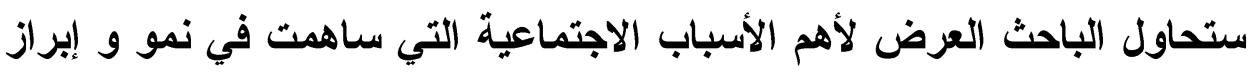
المناطق العشوائية والتى تمثلت فى عنصرين الاسياب الاجياعة هامين هما الزيادة السكانية

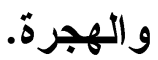

\section{أو-الزيادة السكانية.}

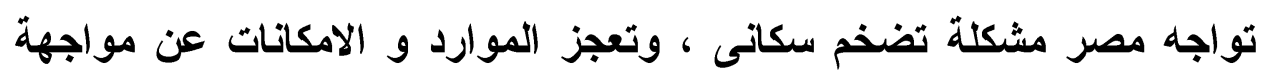

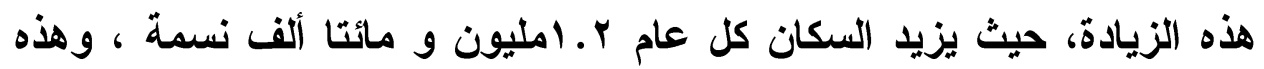

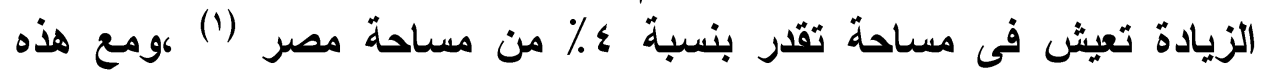

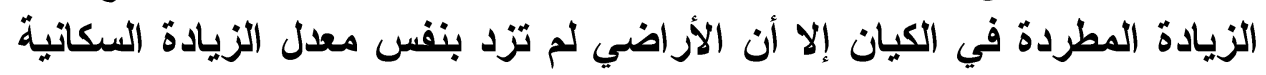

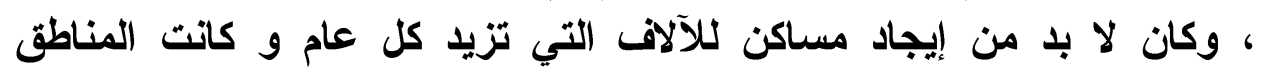

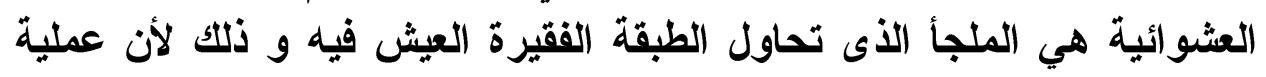

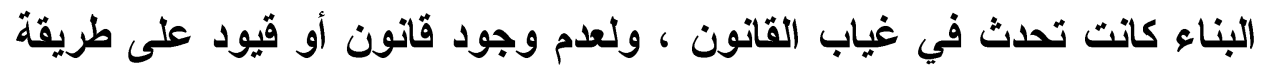

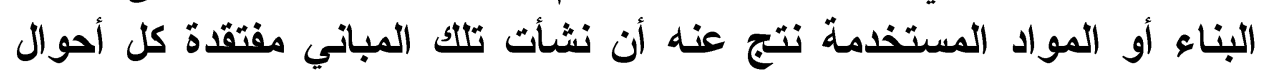

التخطيط في المعمار (r) البناء المواد بـ-الهيرة:

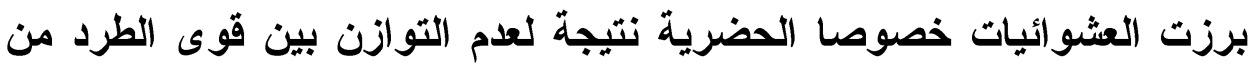
الريف و قوى الجذب إلى الحضر، فالريف لم يعد قادرا اقتصاديا و اجتماعيا و لون الطرد

(' ) حنفى محروس حسانين. احتياجات المناطق العشو ائية ، مجلة كلية الاداب، جامعة اسيوط

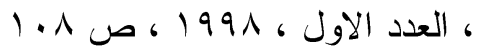

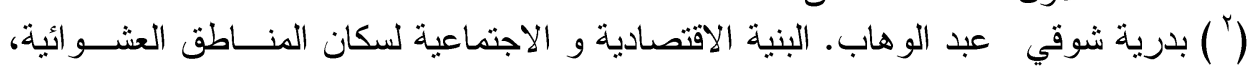

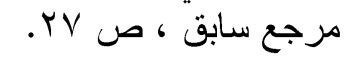


ثقافيا على الاحتفاظ بأبنائه كما أن الحضر لم يعد قادرا على استيعاب العديد من

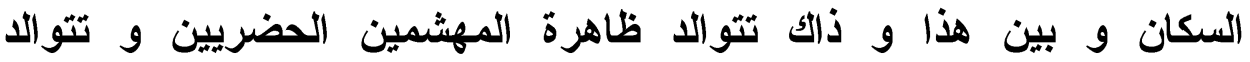
العثوائيات (1) (1)

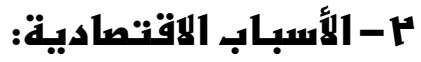

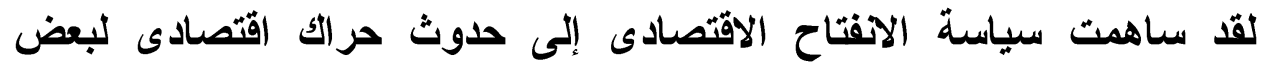

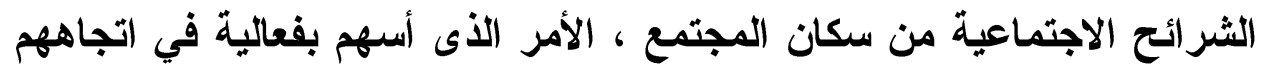

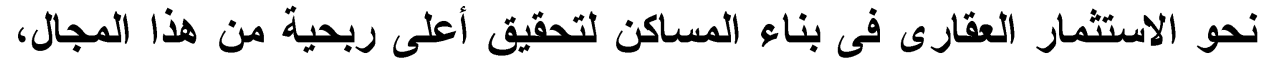

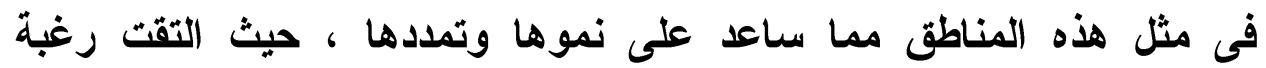

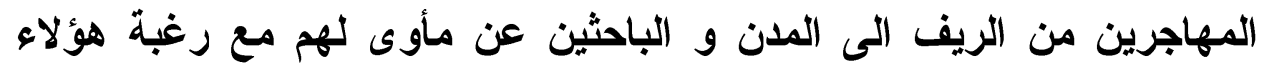

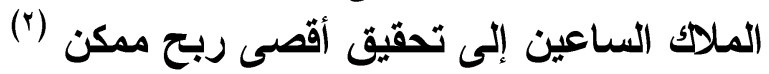
تبابل

تجابه ظاهرة النمو العمرانى جملة مشكلات و صعوبات إدارية بعضها ذات

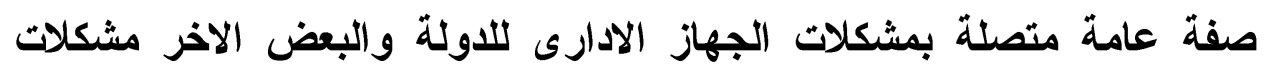

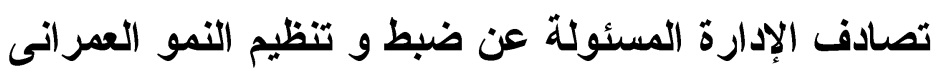

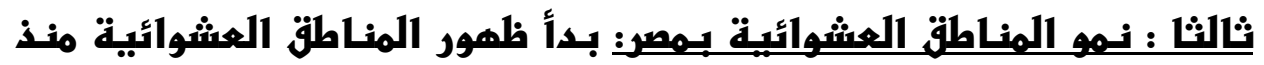

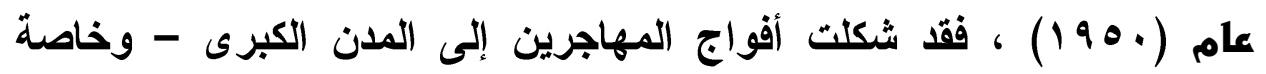

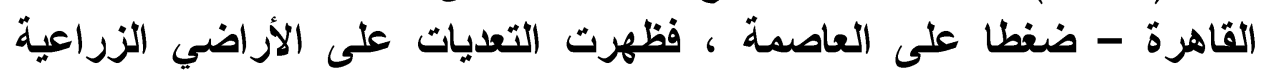

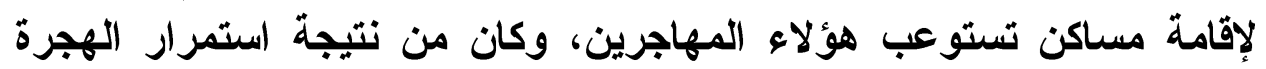

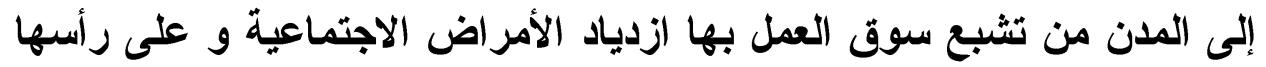

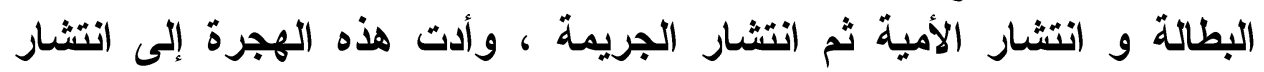

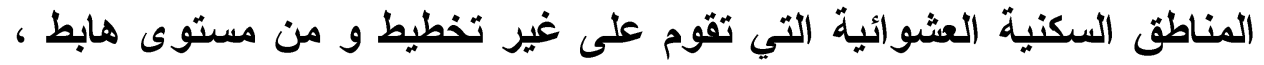

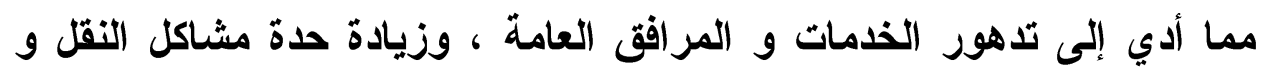

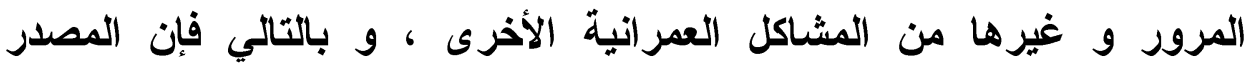

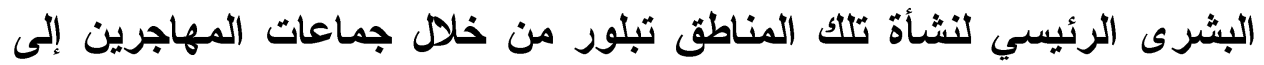

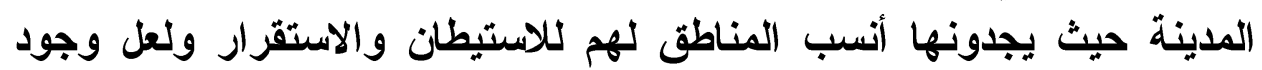

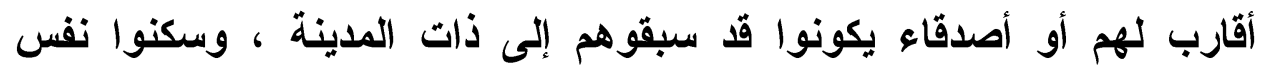

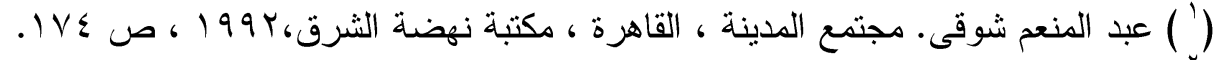

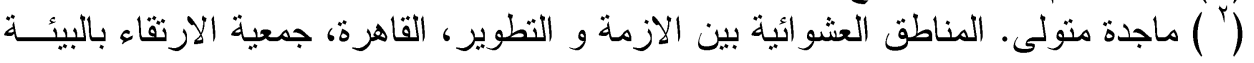

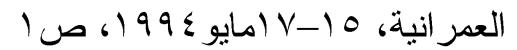




\section{العشوائيات ونمو معدلات الامية والتسرب الدراسى دراسة ميدانية في منطقة عشوائية بمدينة سوهاج}

المدينة من أكبر الاوافع التي تساعد على تركيز المهاجرين بمناطق بعيدة عن

(المدينة (1)

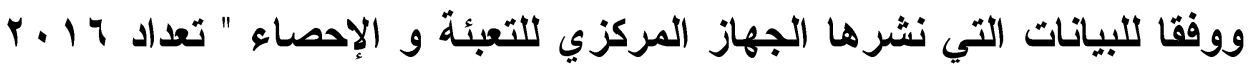

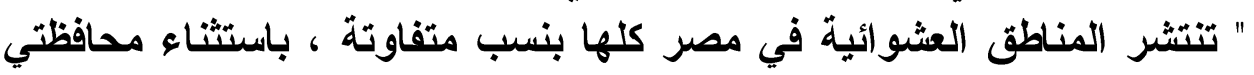

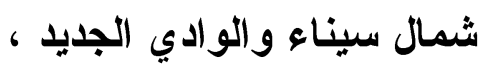
تقع محافظة سوهاج في الترتيب الرابع عشر على محافظات الجمهورية من التوات

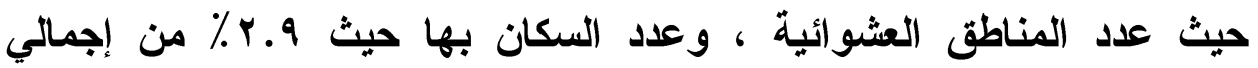

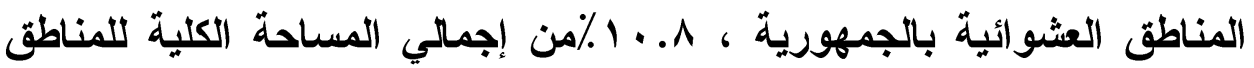

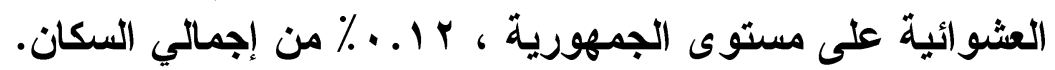
الامبة والتنسرب الدراستى :

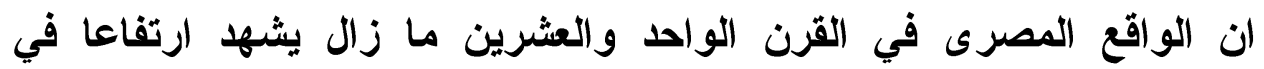

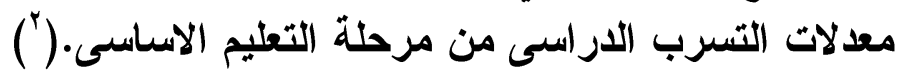

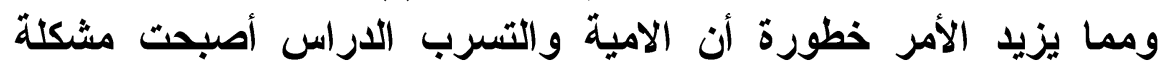

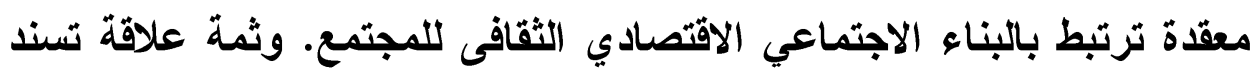

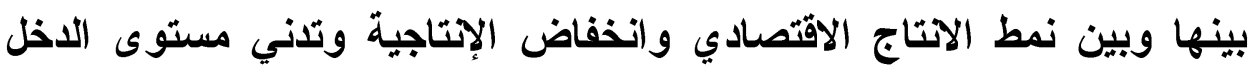

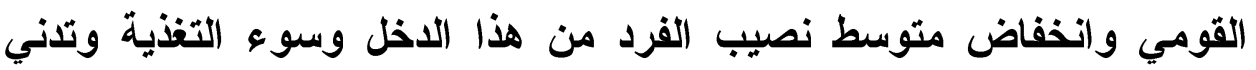

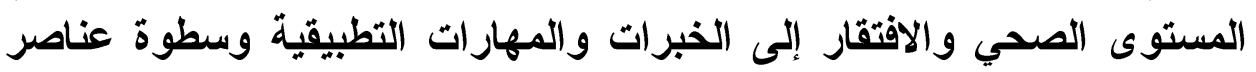

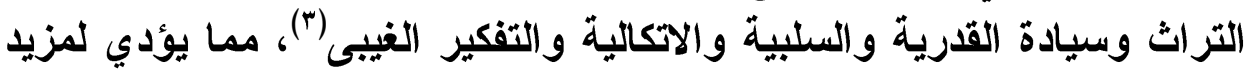

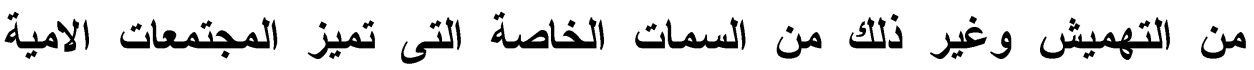
والتسرب الار اس المتخلفة.

وتسهم عديد من العوامل بثكل مباثر أو غير مباثر في زيادة الأعداد المطلقة

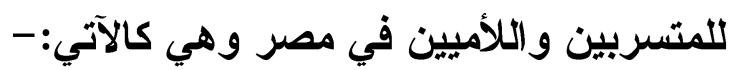

(' ) هالة مصطفى السيد. المناطق العشوائية ، أسباب ظهورها و المشكلات المترتبة عليها و

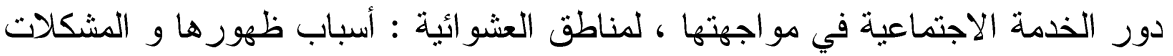

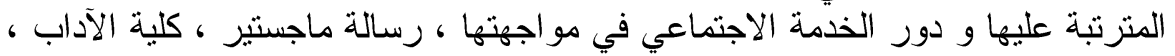

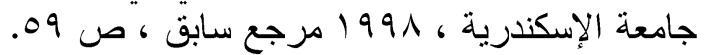

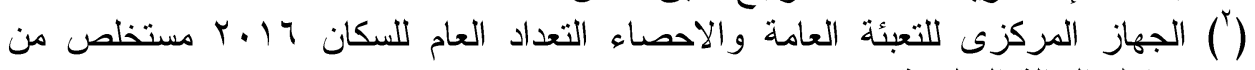
جداول الحالة التعليمية (")-حسن أحمــد الخولــى: محو الأمية مفتاح للتحديث والتمية في البلدان النامية، المجلد الثاني، ص. דז. 


\section{1-غنباب المجتتمع المعلم:-}

وترتكز فكرة المجتمع المعلم أن المجتمع بكل مكوناته ومؤسساته وبكل ثقافته وقيمة وممارساته ويكون محفزاً للتعلم ولمزيد من التعليم وباستمر بكرار

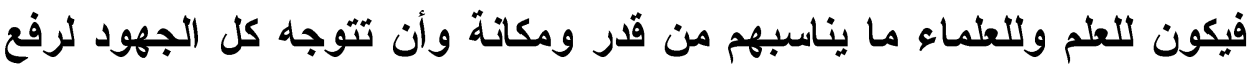
المستوى التعليمي والثقافي للمواطنين بغض النظر عن خلفئ فلفياتهم أو مواقعهم

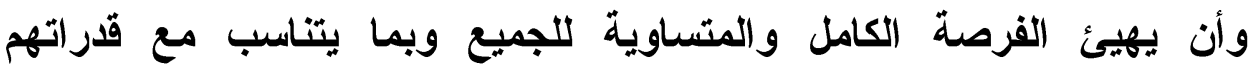
وامكاناتهم من أجل مزيل من التعليم فضلا عن سعى مؤسسات المجتمع إلى ملى فئه

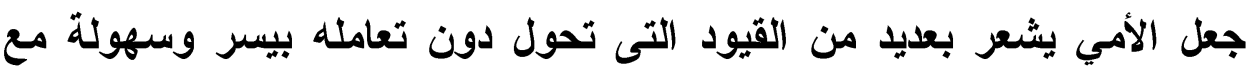
تلكا المؤسسات.

\section{r-الزيادة السكانبة}

من المؤكد أن الزيادة السكانية ليست شراً في حد ذاتها ولكنها تكن كذلك

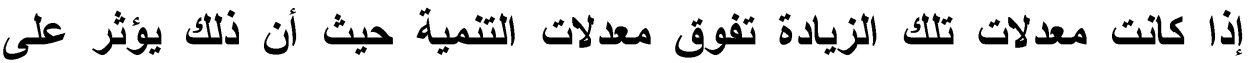

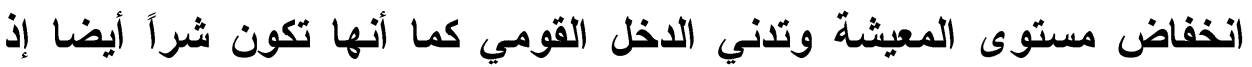
فقت معدلاتها تلك المعدلات التى يحققها المجتمع في خفض نسئة نسبة الأمية.

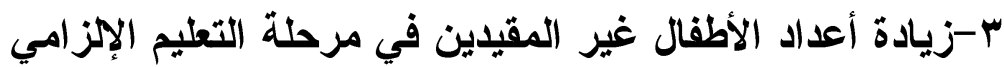

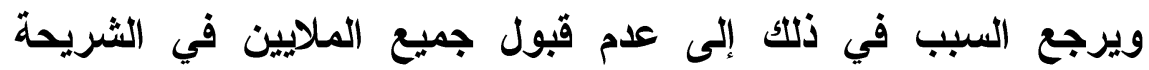
العمرية (ا-^) وهو ما يطلق عليه معدل القبول وكذلك على الاحتفاظ لتلثك

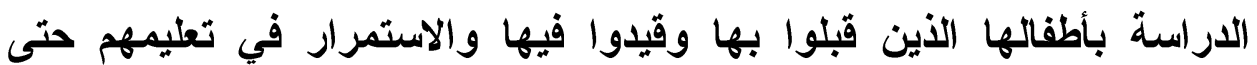

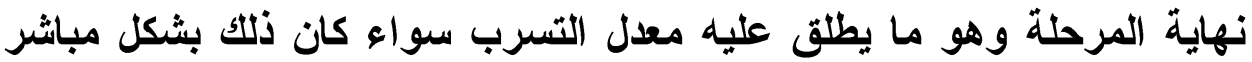

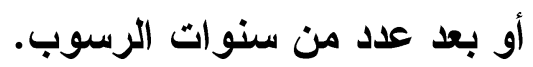

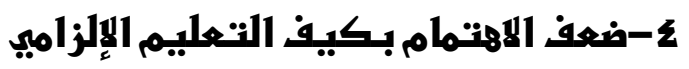

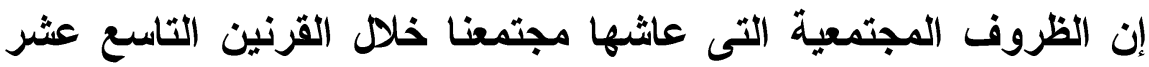
والعشرين قد فرضث أوضاعا جعلتنا نهنم بالجوانب الكمية في التعليم وذلك الكيات

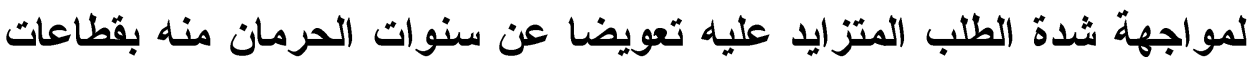

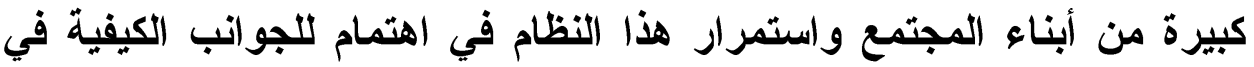

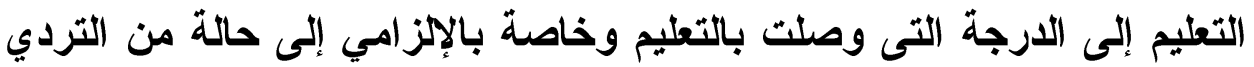

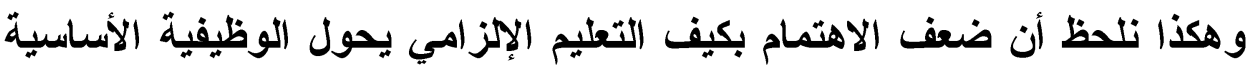
للمدرسة من مؤسسة تهتم بزيادة أعداد الأميين سنوياً. 


\section{0-ارتداد فى مهى أميتهم إلى الأمية}

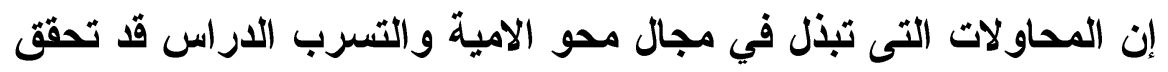

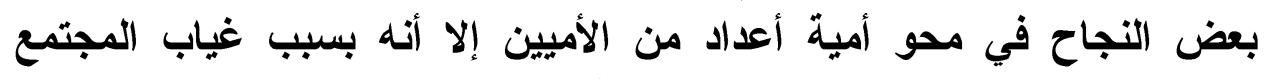

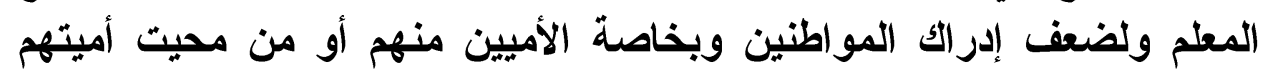

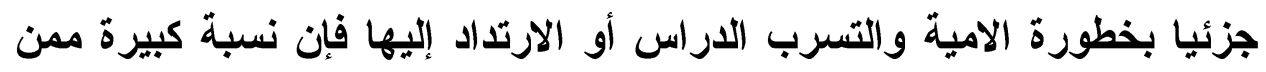

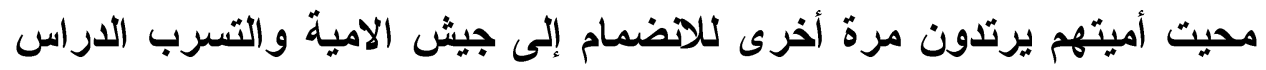

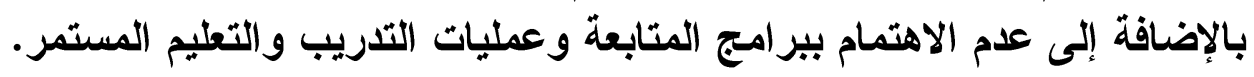

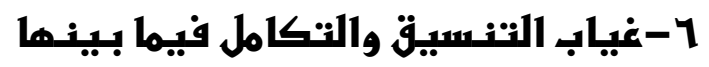

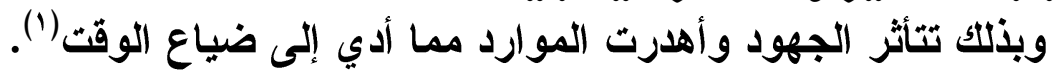

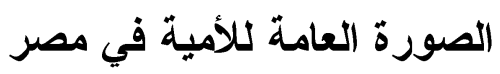

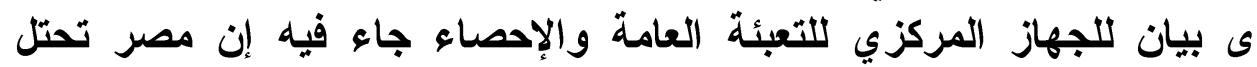

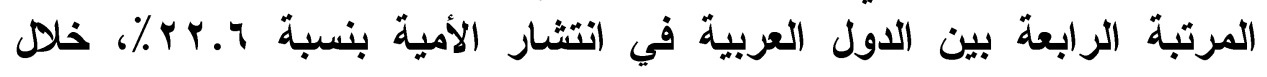

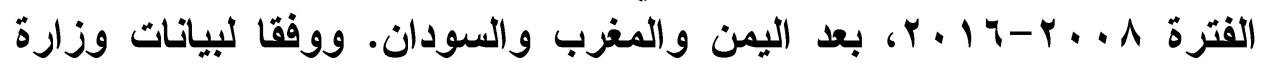

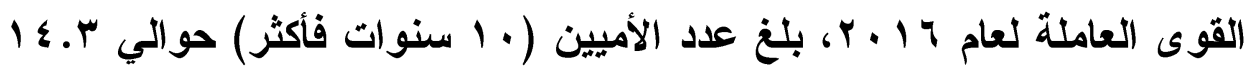

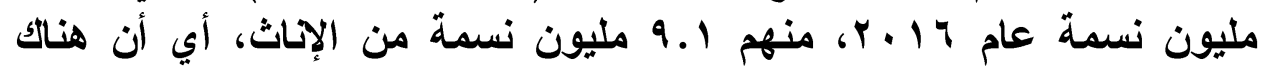

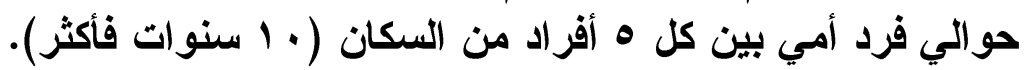

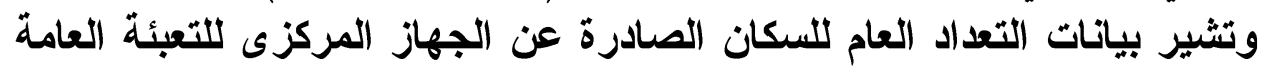

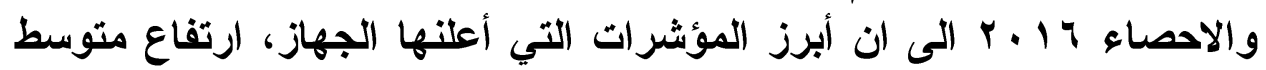

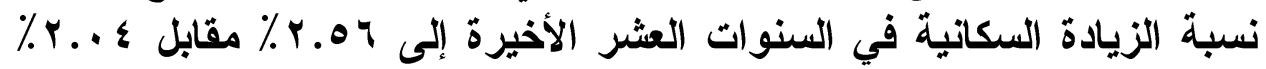

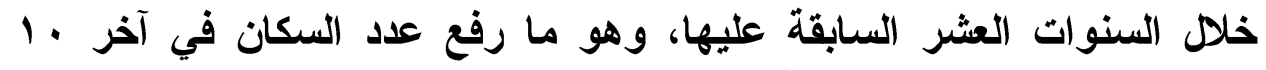

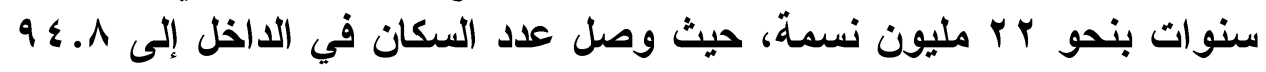

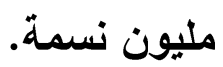

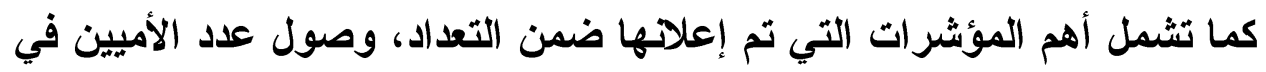

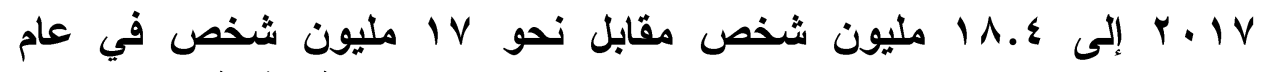

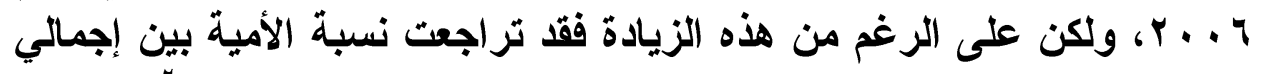

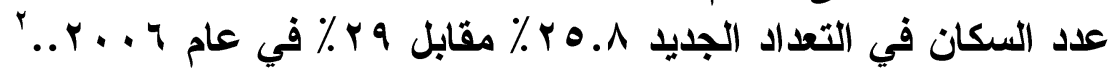

(')- همام بدراوى زيدان ودسوقي حسين عبدالخليل: إدارة عمليات التخطيط لمحو الأمية :

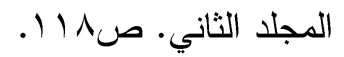

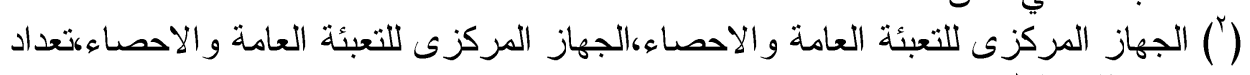

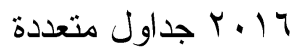




\section{معدلا ت لتنسرب الدراستى 11+r:}

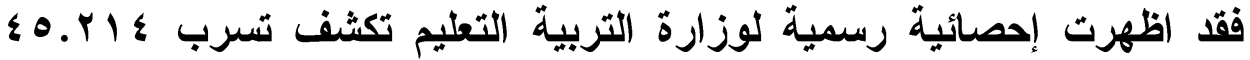
تلميذا بالمرحلة الابتدائية و. عه. 1 و بالإعدادية.. وتؤكد: محافظة أسيوط

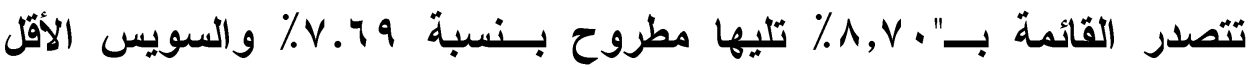
\% 。 $\mathrm{V} \longrightarrow$

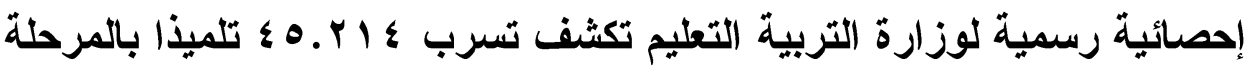

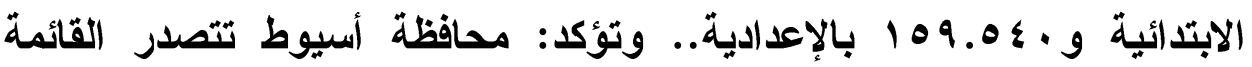

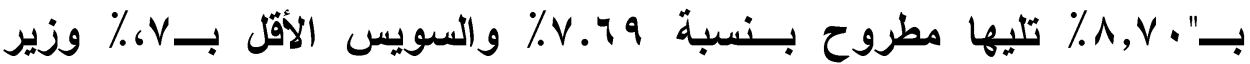
التربية و التعليم وطبقا لأخر احصائيات صادرة عن وزارة التربية والتعليم والتعليم الفنى،

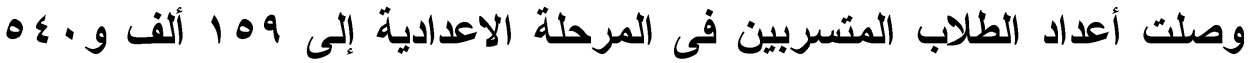

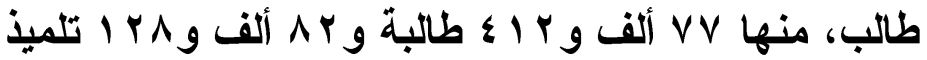

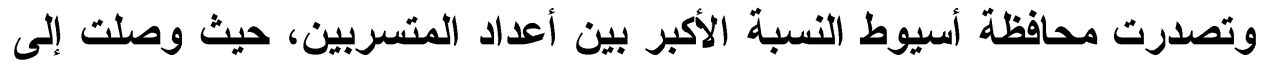

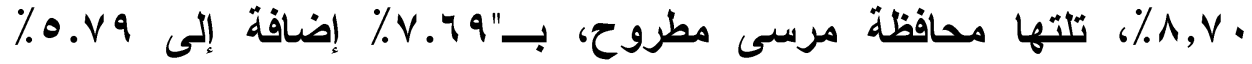
بمحافظة الأقصر، كما حظيث محافظة الوادى الجديد بمركز متقدم بين الطلاب

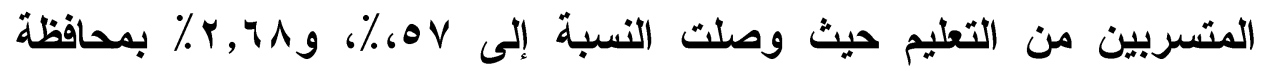

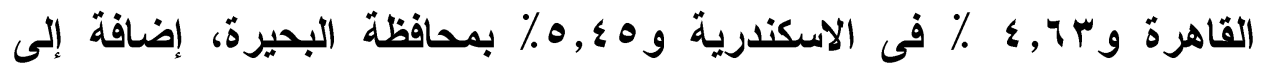

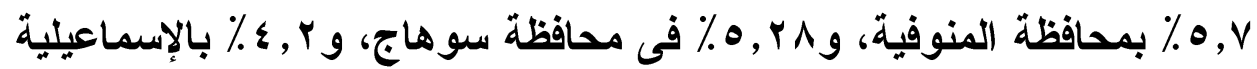

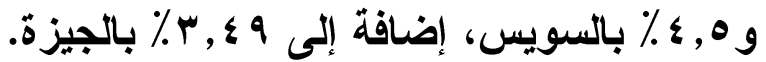
وكشفت الاحصائيات عن أن نسب التسرب من المبات المدارس في المرحلة الابتدائية

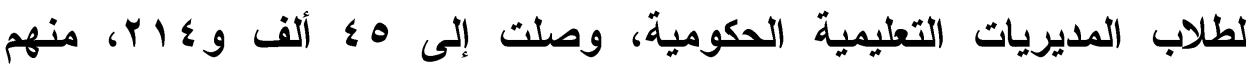

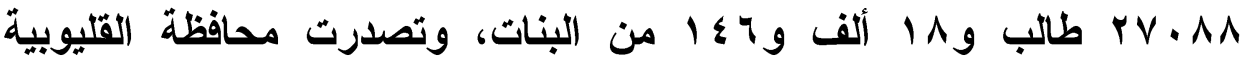

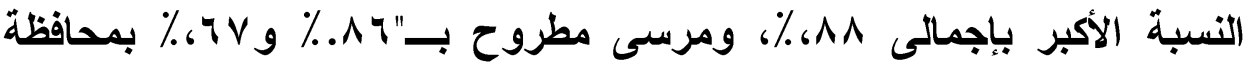

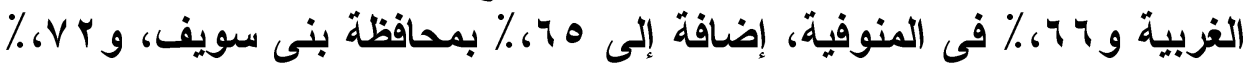

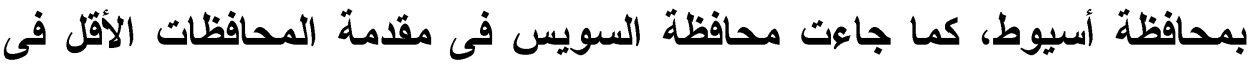

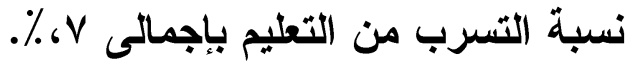

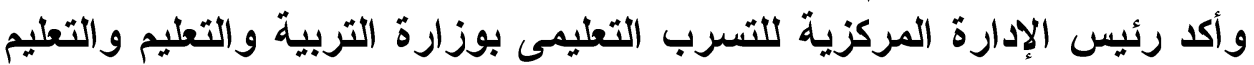

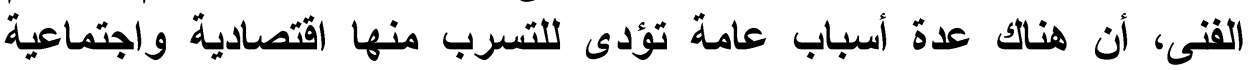




\section{العشوائيات ونمو معدلات الامية والتسرب الدراسى دراسة ميدانية في منطقة عشوائية بمدينة سوهاج}

وثقافية تدفع الطالب لترك المدرسة والتسرب منها، على رأسها الفقر الأى التى التها.

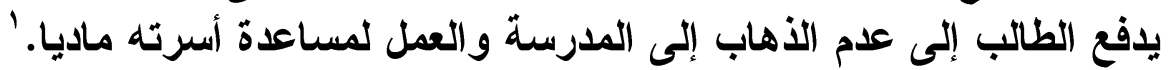
وأوضح أن هناك خطة تمثلت فى وضع تصور الته من خلاب الته التربية الاجتماعية

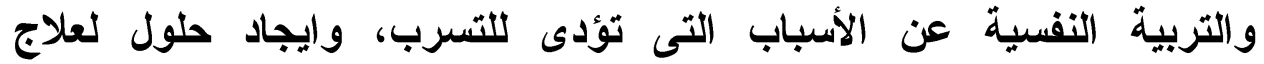

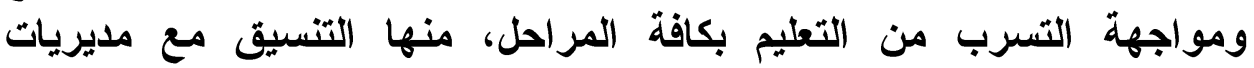

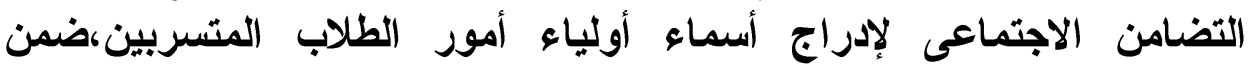

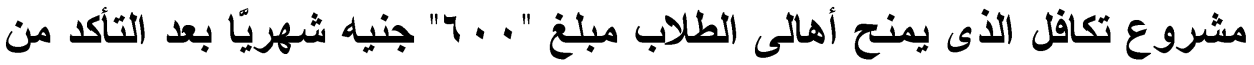

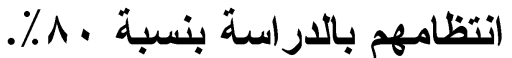
وقالت رئيس الإدارة المركزية للتسرب التعليمى بوزية التهارة التربية والتعليم والتعليم

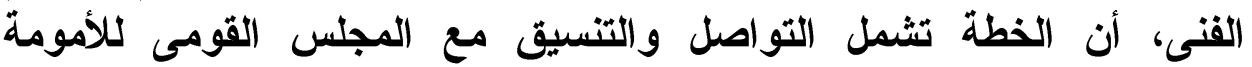

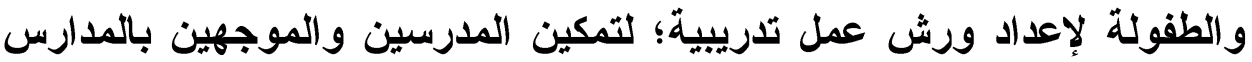

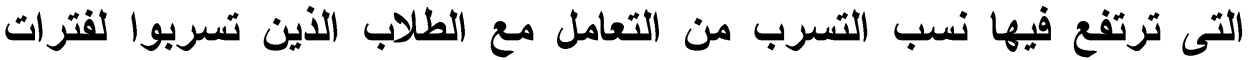

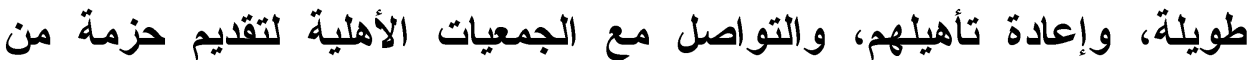

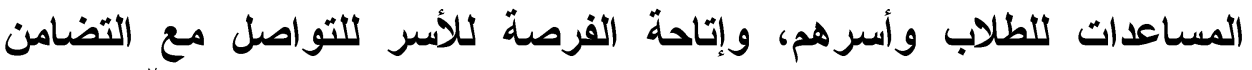

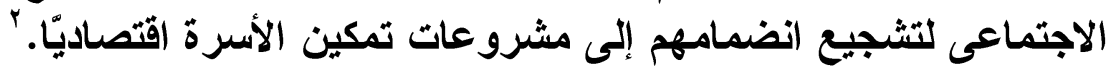

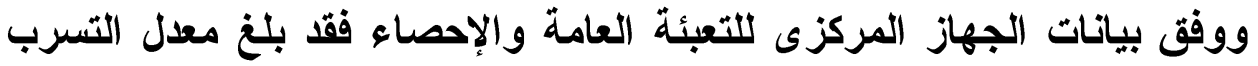

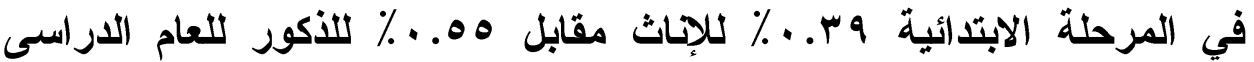

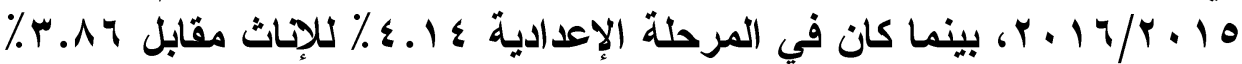

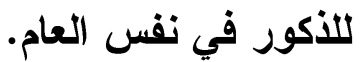

\section{الدراسات السابقةة.}

ا ـ دراسة محمود جاد سنة ه1911 عن خصوبة سكنى المقابر بمدينة

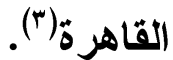

وقد أجريت الاراسة على سكنى مقابر الثافعي والقرافة الثرقية بمدينة

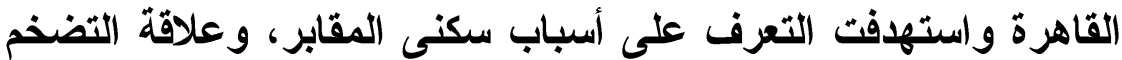

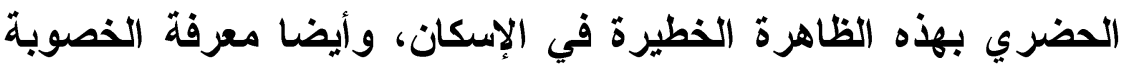

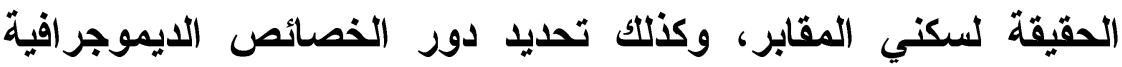

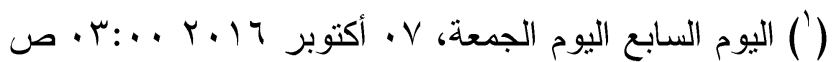

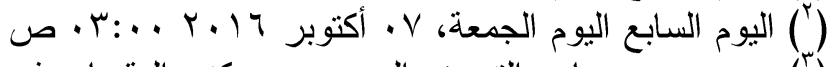

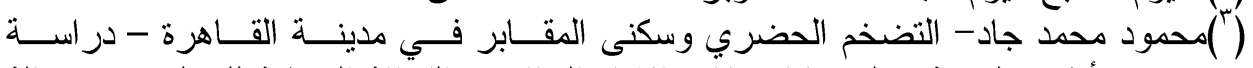
سوسيو أنثروبولوجية، على سكان مقابر الإمام الثافعي و القرافة الفئ الثرقية للمسلمين - رسالة ماجستير - غ.م- كلية الآداب- جامعة القاهرة (1910 (1) ). 
والفيزيقية والاقتصادية لسكان المقابر، وهل الاتجاهات والمعتقدات

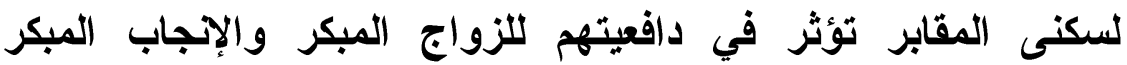

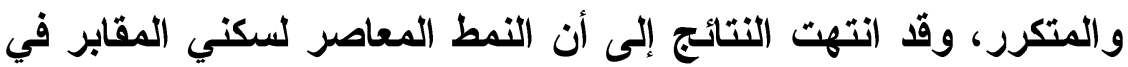

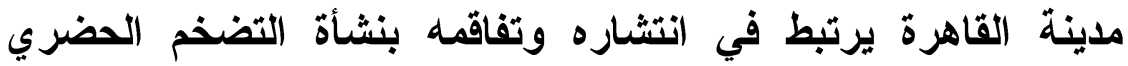

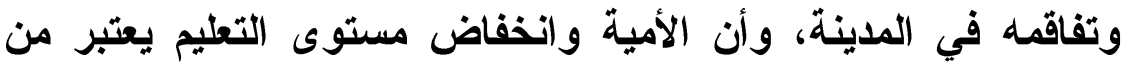

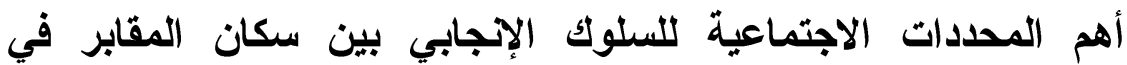
المجتمع البحثي، كما جاءت المنفعة الاقتصادية المتوقية الإبية من الأطفال

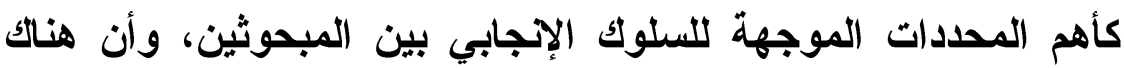

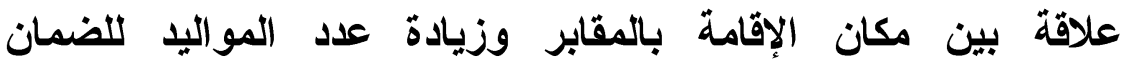

$$
\text { الاجتماعي والأمني. }
$$

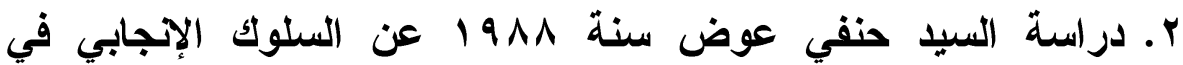

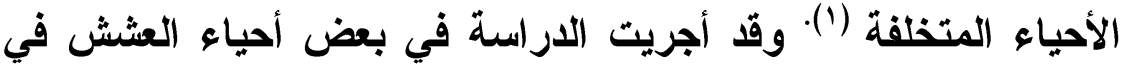

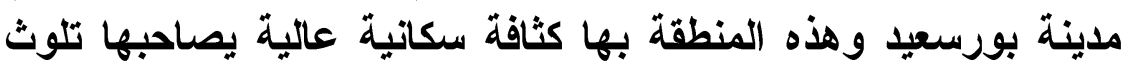

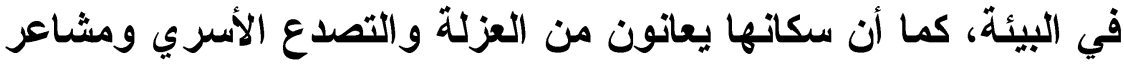

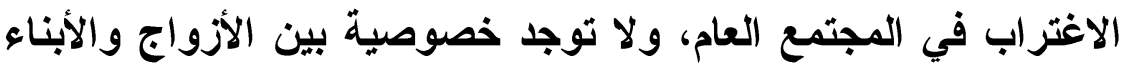

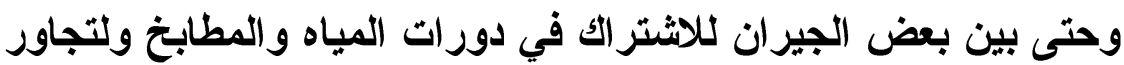
وتقارب غرف النوم وضيق مساحتها. وانتهت الاراسة إلى أن الشكل الفيزيقي للمكان لم يكن بمنأى عن فئن المؤثرات التاريخية التي أسهمت في بناء أحياء العشش ونشئ أنموها في

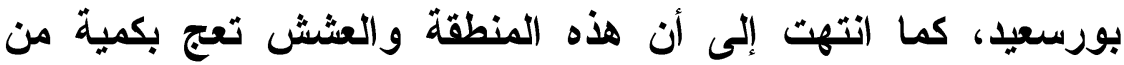

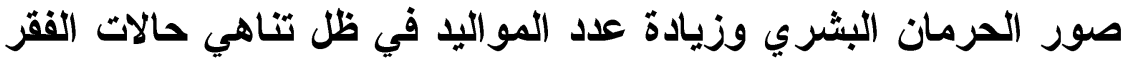

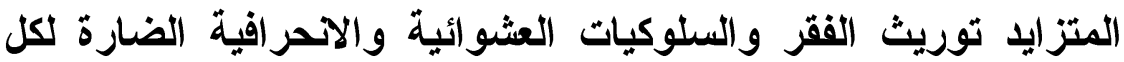

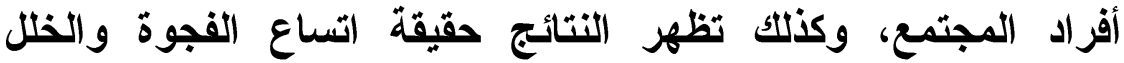

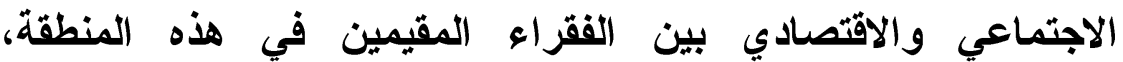
والأغنياء المستفيدين من تطبيق سياسة الافقتاح الاقتصادي، بمدينة 


\section{العشوائيات ونمو معدلات الامية والتسرب الدراسى دراسة ميدانية في منطقة عشوائية بمدينة سوهاج}

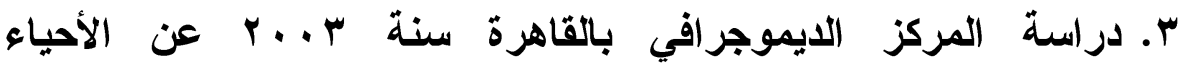

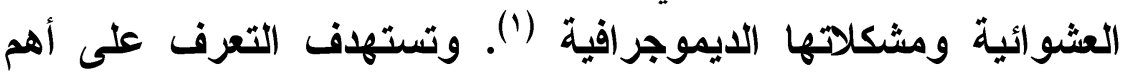

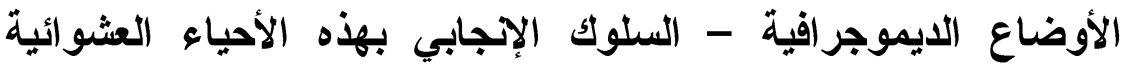

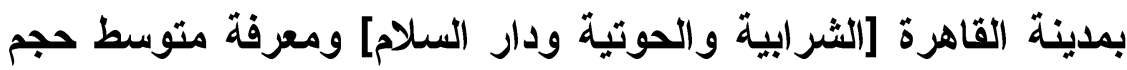

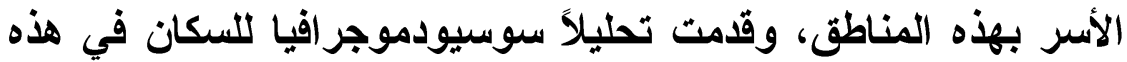

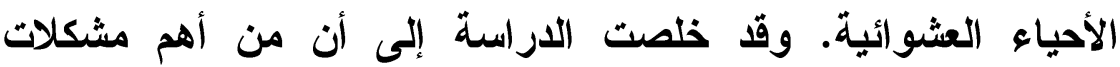

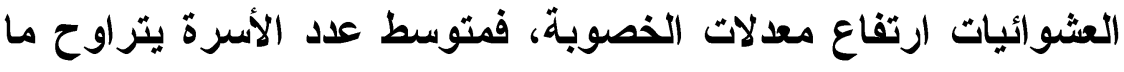

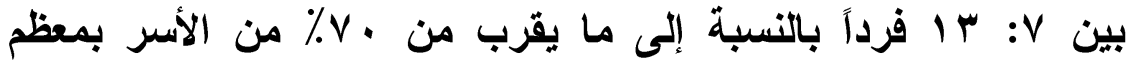

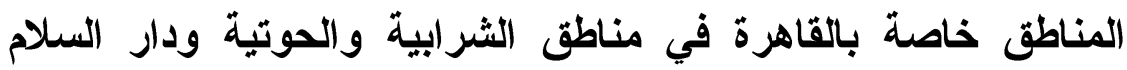

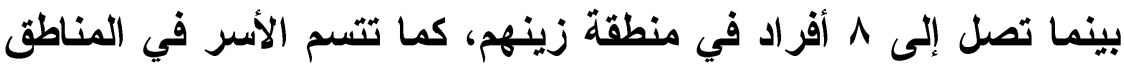

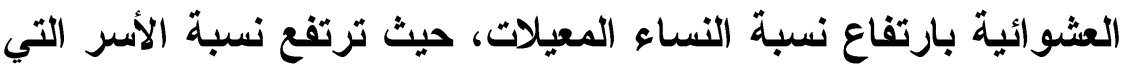

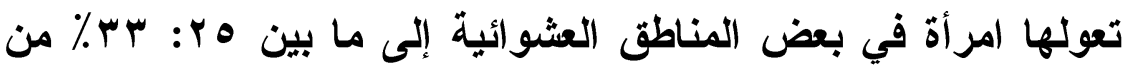

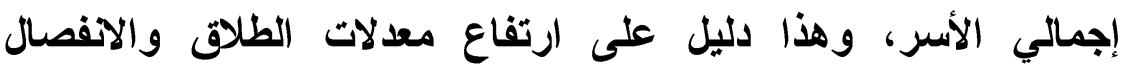

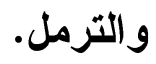

كذلك يرتفع معدل النمو السكاني بالمناطق العشوائية ليصل في حي

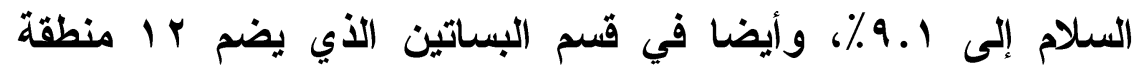

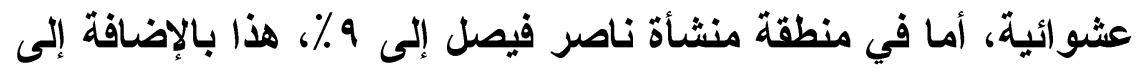

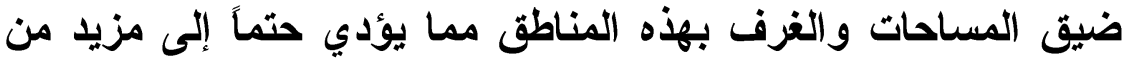

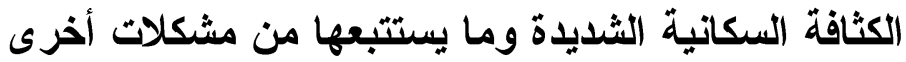

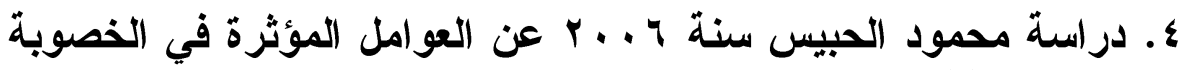

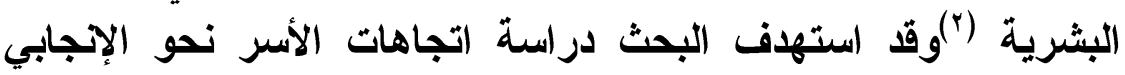

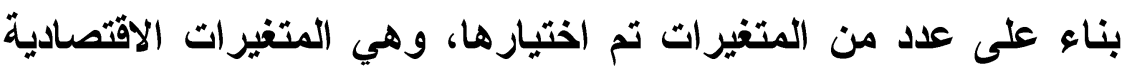
[الدخل ومهنة الزوج ومهنة الزوجة] والاجتماعية (المستوى التعليمي التئية

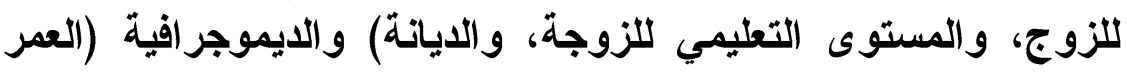

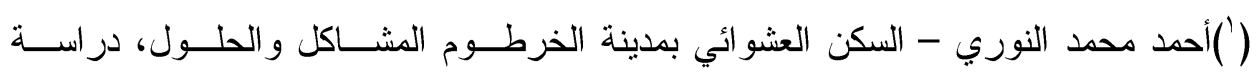

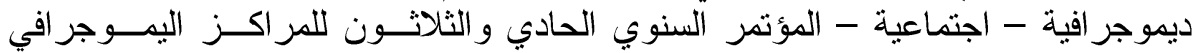

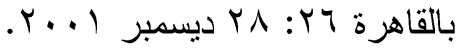

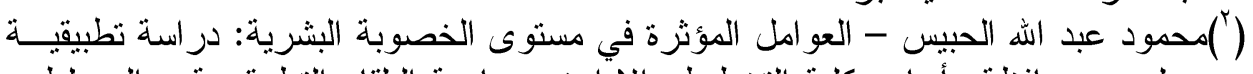

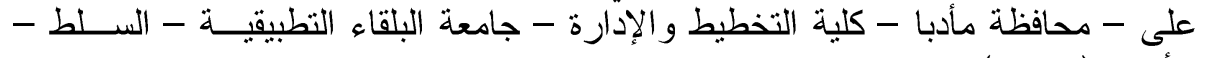

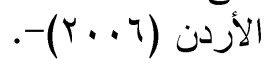


عن الزواج الأول، واستخدام وسائل منع الحمل، وطول مدة الحياة

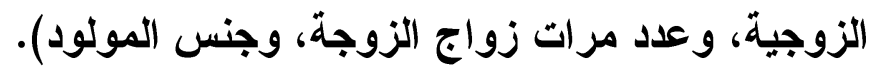

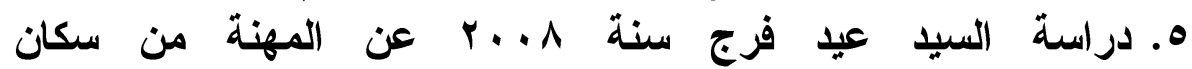
العشوائيات(1).. وقد أجريث الاراسة في المناطق العثوائية بمدينة

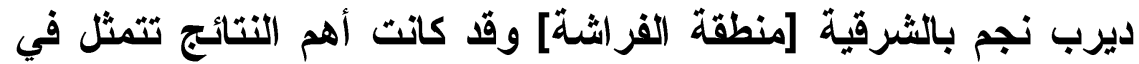

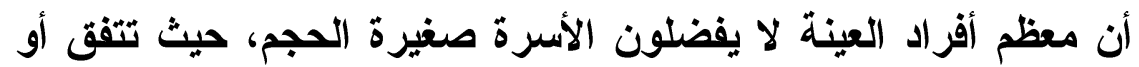

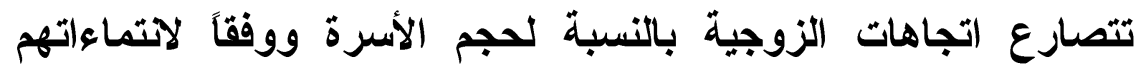

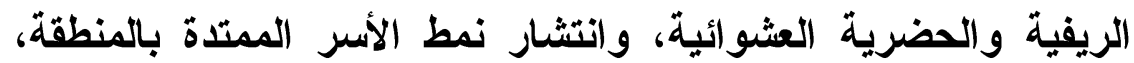

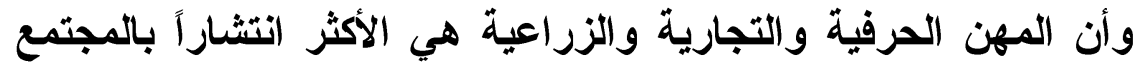

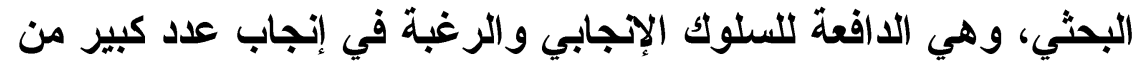

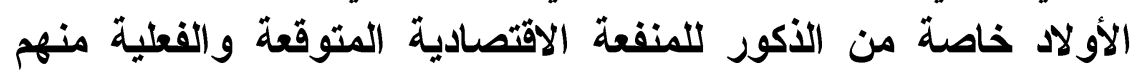

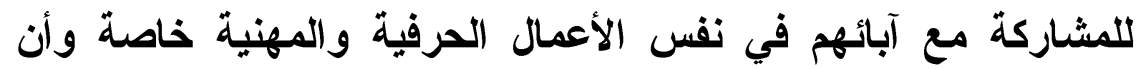

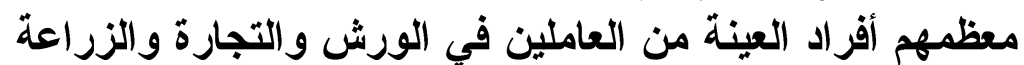

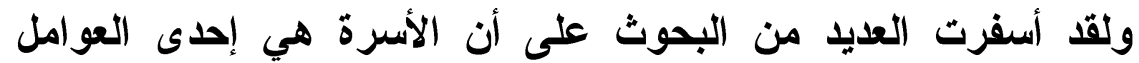

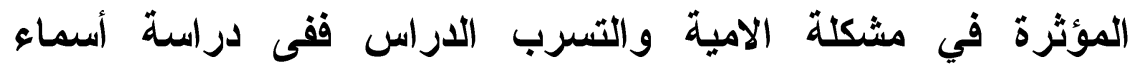

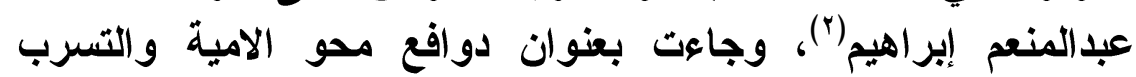

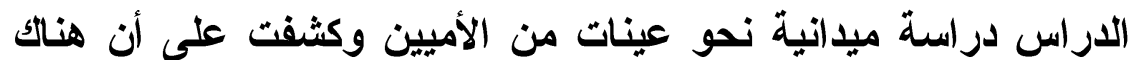

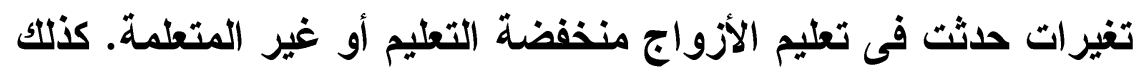
في تعليم الزوجات حيث انخفضت نسبة الأبناء التى تعثبر التهر أمهاتهم

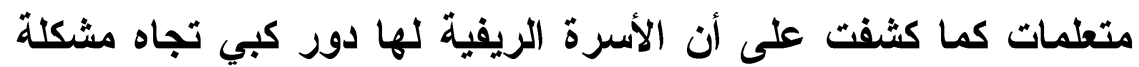

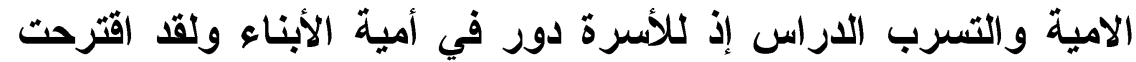

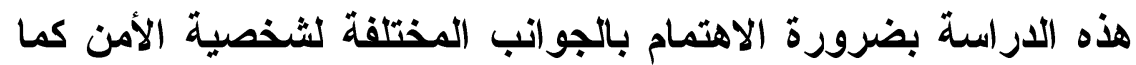

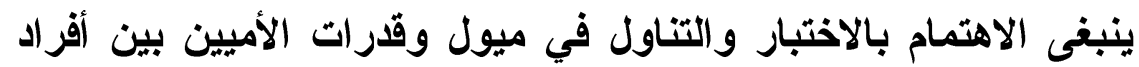

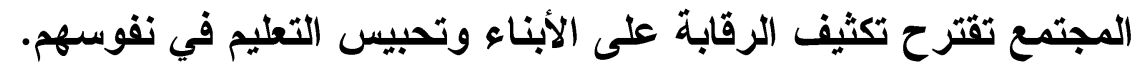

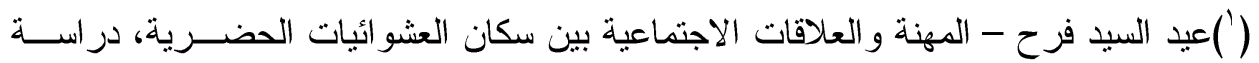

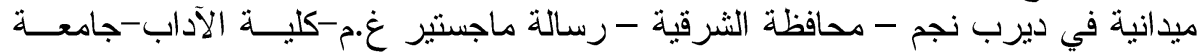

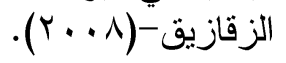

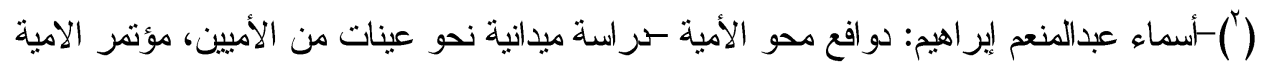

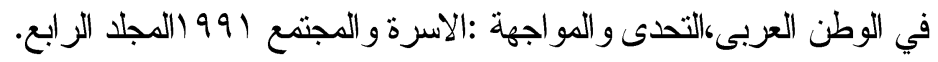




\section{العشوائيات ونمو معدلات الامية والتسرب الدراسى دراسة ميدانية في منطقة عشوائية بمدينة سوهاج}

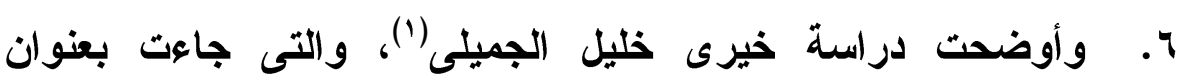

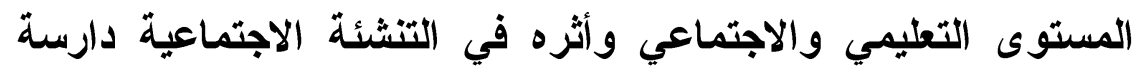

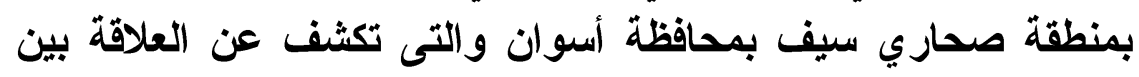

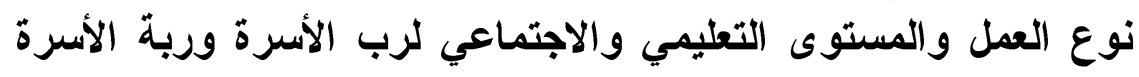

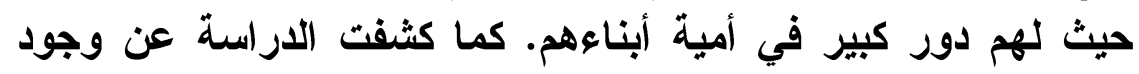

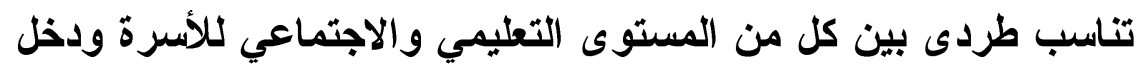

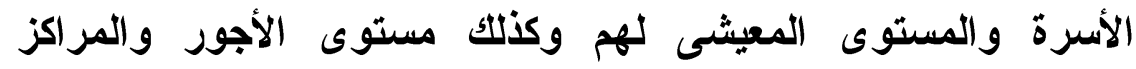

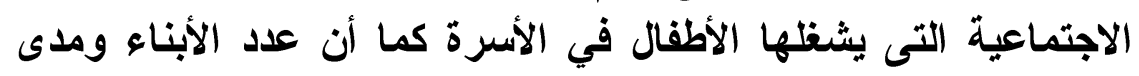

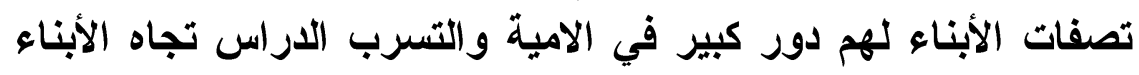

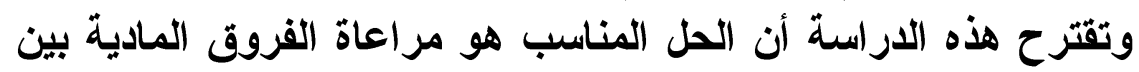

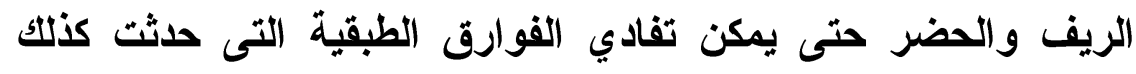

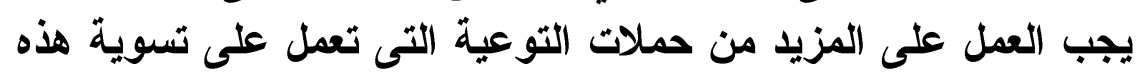

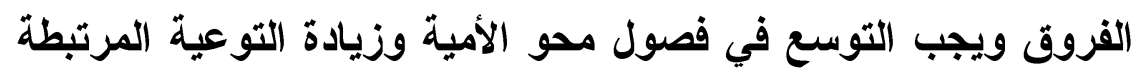

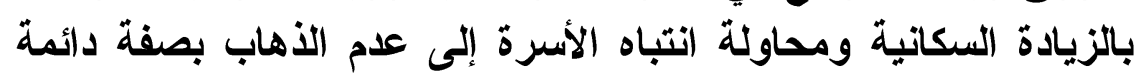

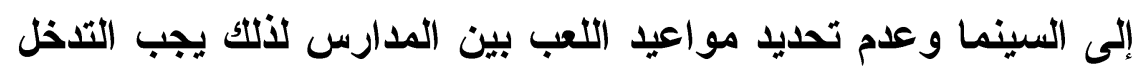

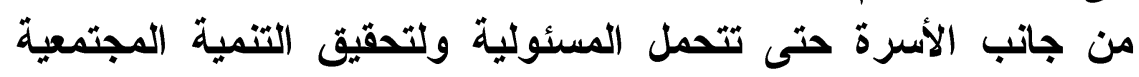

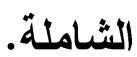

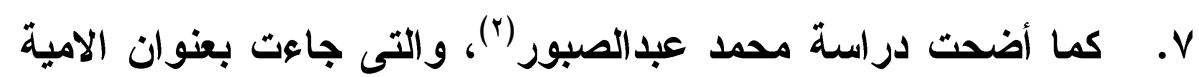

$$
\text { و التسرب الدراسى والفقر من المنظور الإقتهادي. }
$$

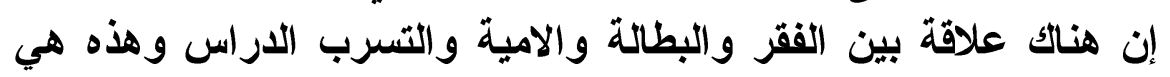

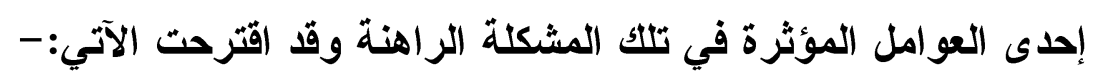

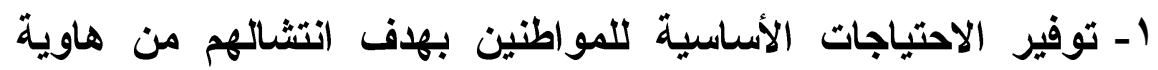

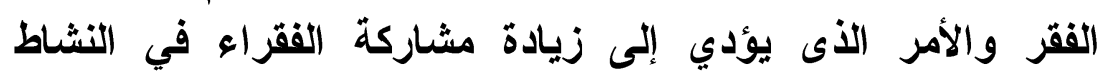
الاقتصادي و العمل على الحد من تفاوت الدخول وإعادة لفئ توزيع الدخل.

(')- خيرى خليل إبراهيم الحميلى: مؤتمر الامية في الوطن العربى،التحدى والمواجهة

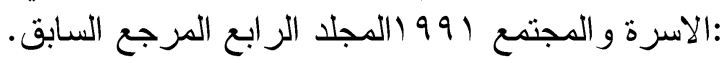

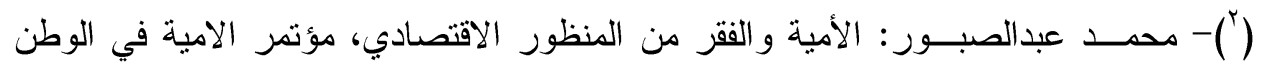

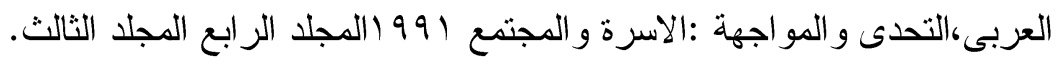


r- الاهتمام بالجدوى وليس الصور بعملية الامية والتسرب الاراس

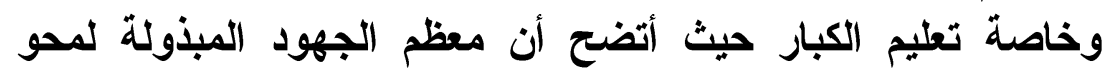

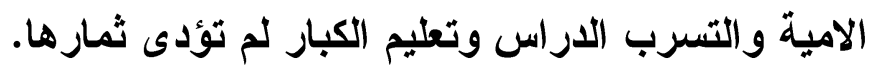

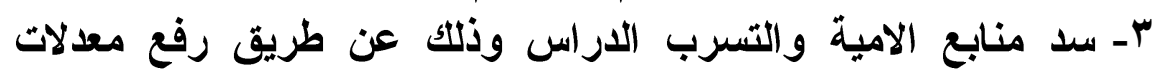

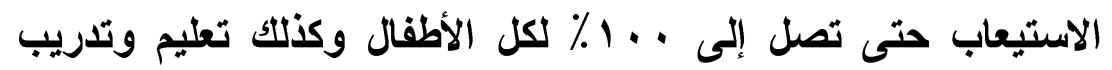

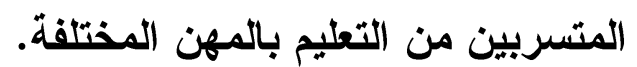

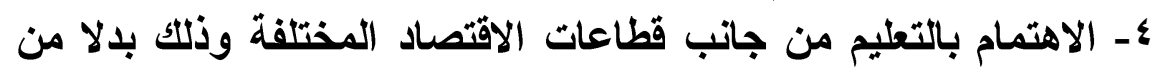

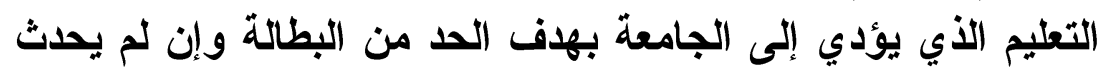
ذلك فسيقعون في دائرة الفقر.

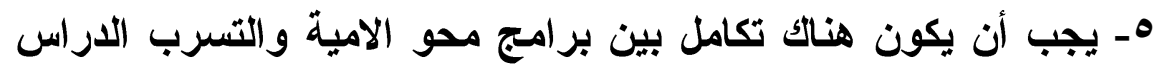

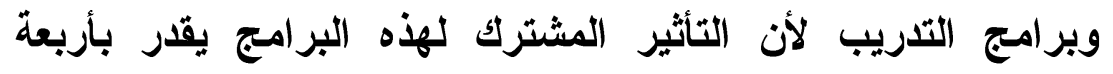
أضعاف تأثير كل منهم على حدة والعمل على تلثير التهيع توطنين

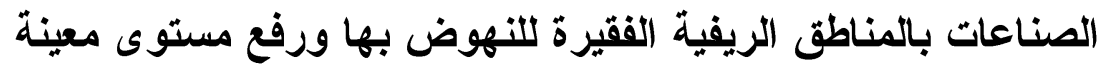
سكانها بالإضافة إلى الاهنمام بتعليم أولادهم.

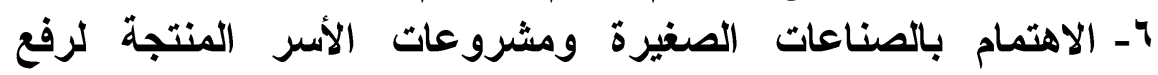

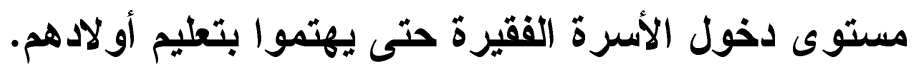

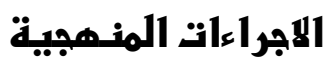

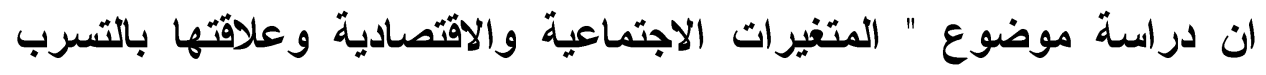

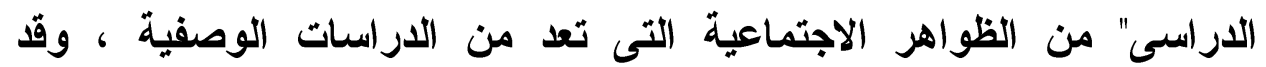

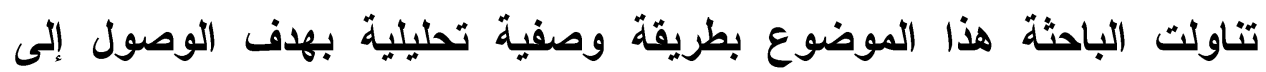

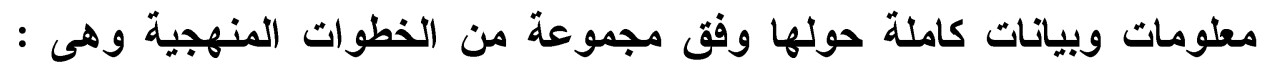

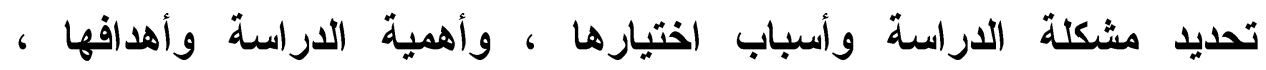

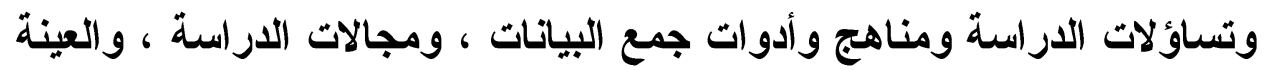

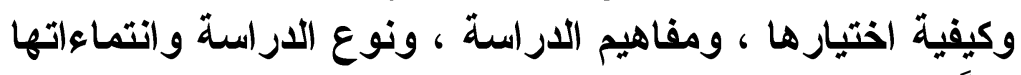

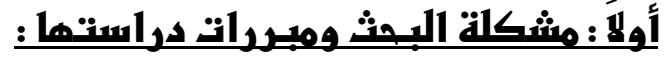
أولا: مشكلة الدراسة وأهميتها:

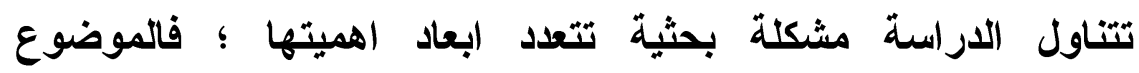

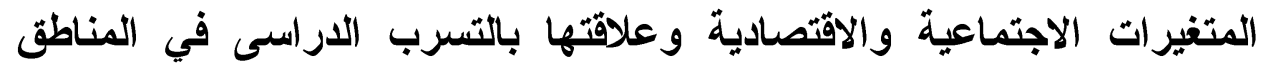

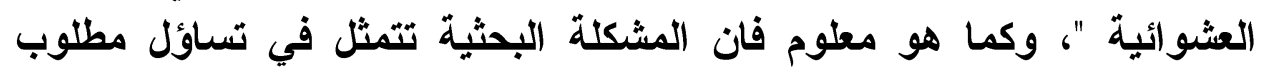




\section{العشوائيات ونمو معدلات الامية والتسرب الدراسى دراسة ميدانية في منطقة عشوائية بمدينة سوهاج}

الاجابة عليه،وعلى هذا فان قضية هذا البحث ومثكلته هى تسرب التلاميذ من التعليم في المناطق العشو ائية الهابة

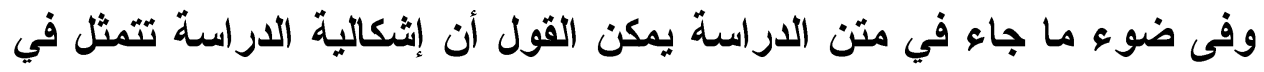

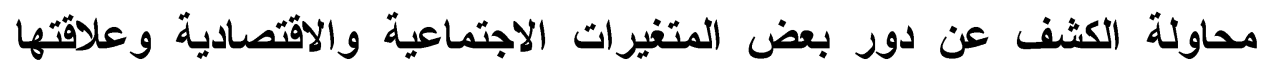

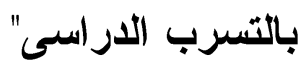

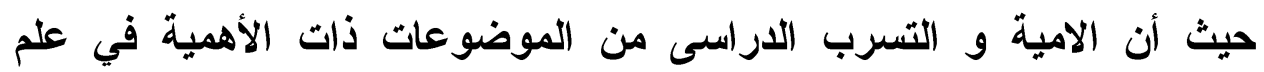

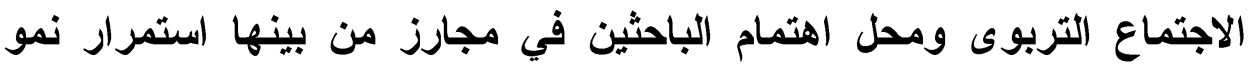

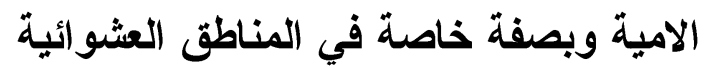
تحاول الباحثة التطرق لموضوع المتفيرات الاجتماعية والاقتصادية وعلاقتها

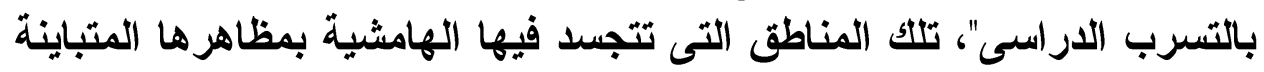

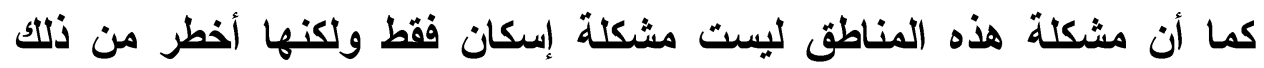

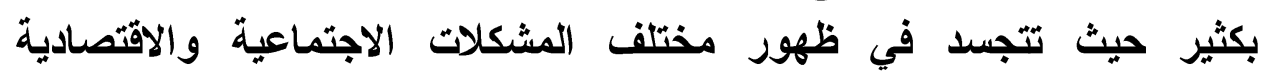

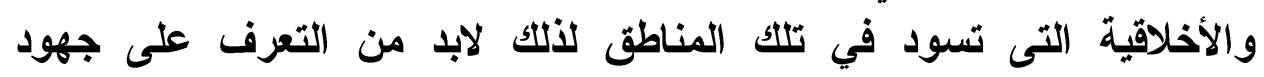

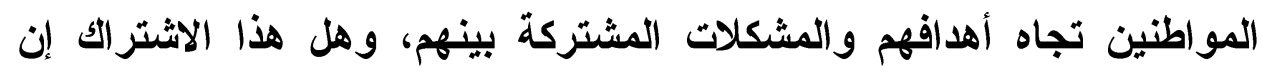

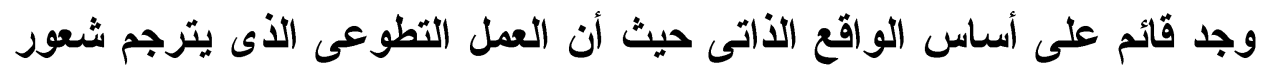

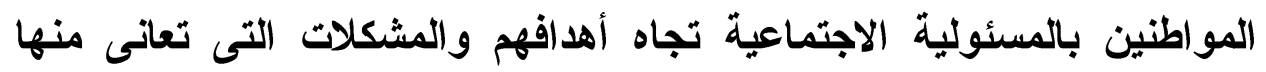

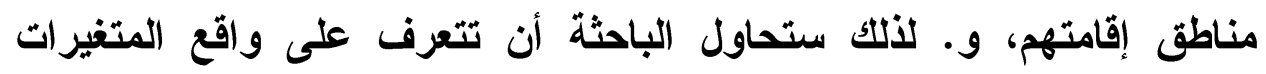

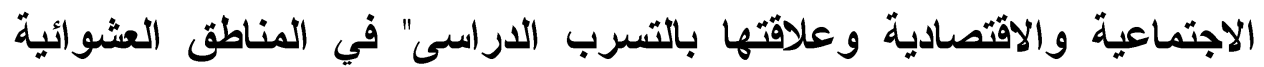

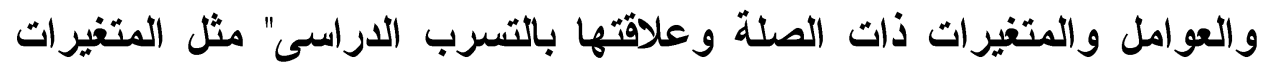

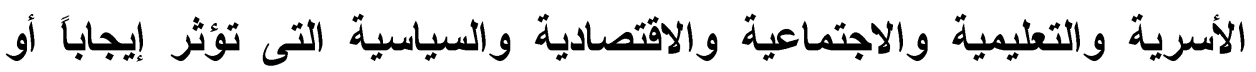

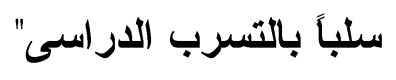

\section{ثانياً : أهمية الدراسة :}

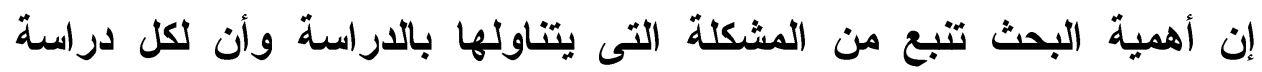

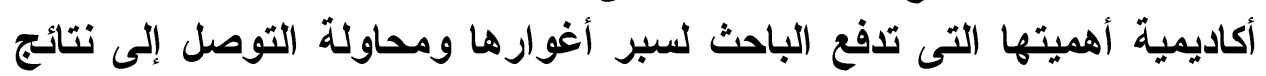

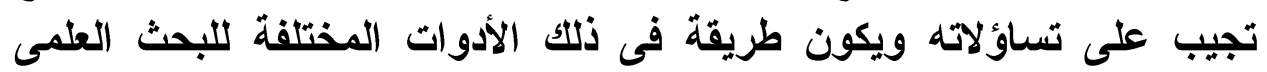

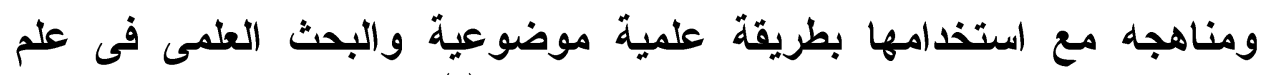

الاجتماع تكون له أهميتين علمية وأخرى عملية علية.

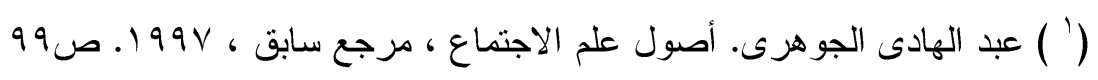


: الاهمية النظرية :ومن ثم فإن المتغير الأول يقع فى مجال إهتمام علم السكان،

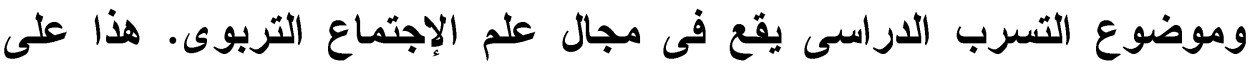
المستوى الأكاديمى، وعلى المستوى التطبيقى فإن كلا المتغيرين يمثلان أهمية

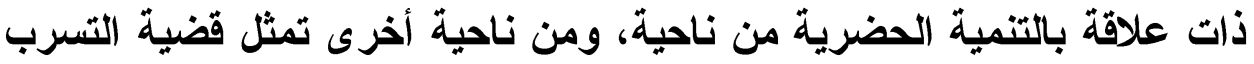

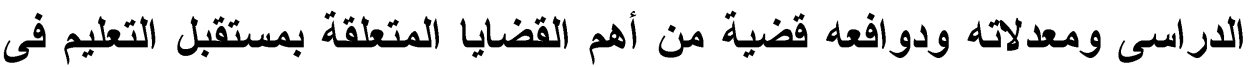

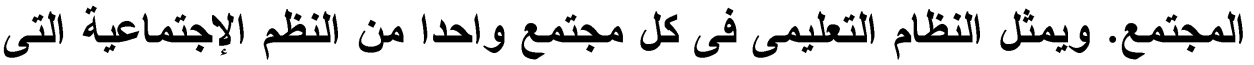

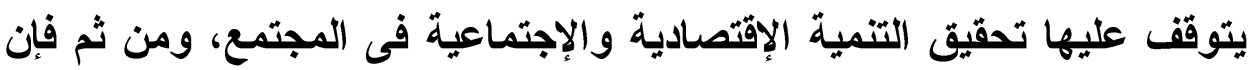

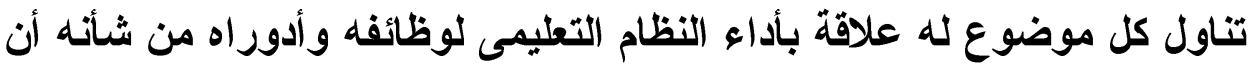

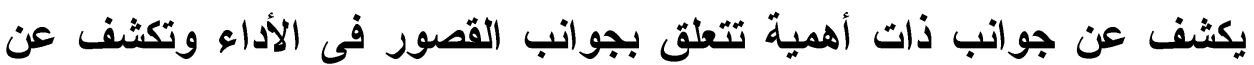
أساليب معالجتها.

تتمثل أهمية هذا البحث في أنه يتناول بالدراسة موضوعاً حيوياً ألا وهو الهو

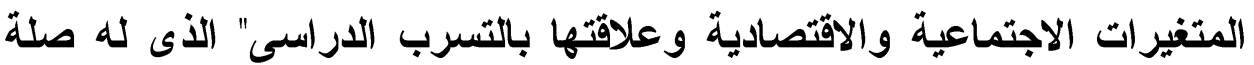

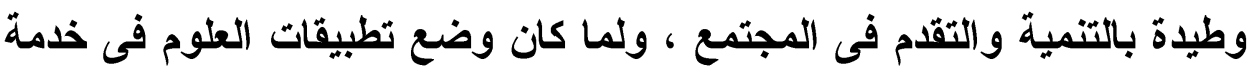

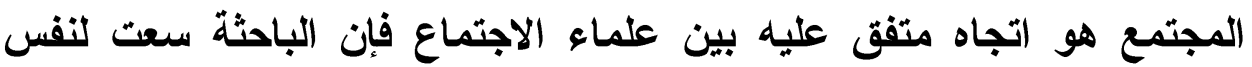
الغرض فى أنه سوف تقوم بعرض ما سوف تتوصل إليه دراستها التطبيقية

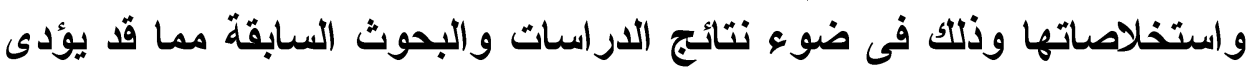

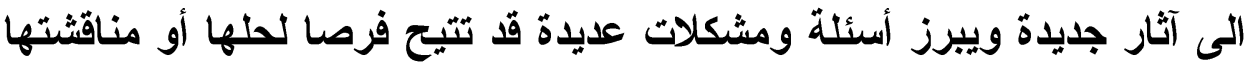

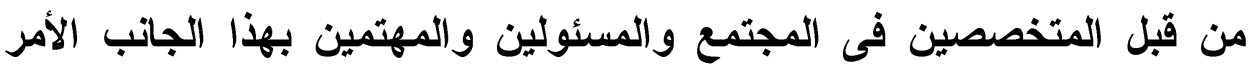

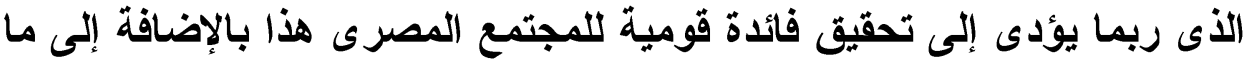
قد يثيره هذا البحث من قضايا واستفسارات يمكن أن تكون مطلقاً أساسياً تبدأ

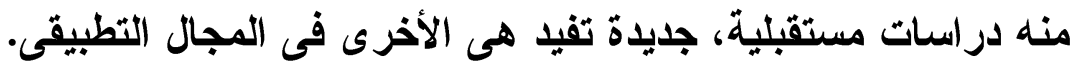

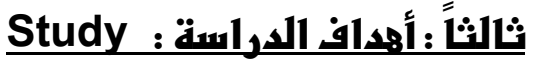

يتجه البحث العلمى فى غايته إلى تحقيق أهداف عامة غير شخصية ذات أله قيمة

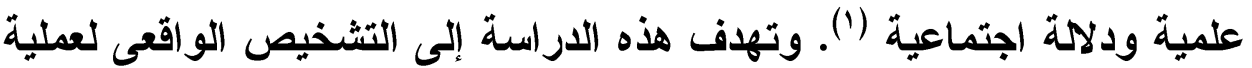

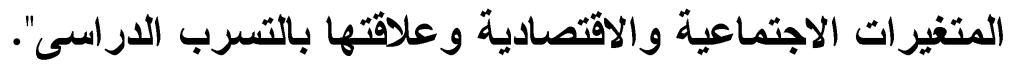

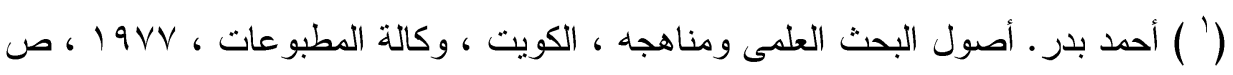
. $v$. 
وينبثق من هذا الهدف بعض الأهداف الفرعية التى تتلخص في الآتى :

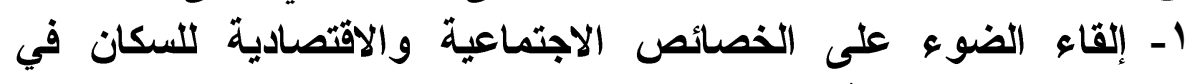
المناطق العشوائية. r- التعرف على الأوضاع الأيكولوجية التى تحيط بالاطفال المتسربين في المناطق العثوائية. r- محاولة الوقوف على أهم العوامل الاجتماعية والاقتصادية التى تؤثر

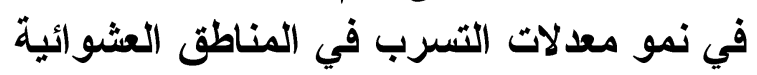

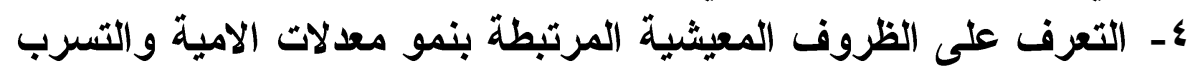
الار اسى في المناطق العثوائية.

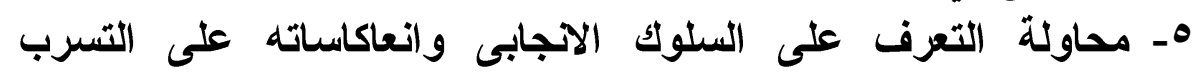
الار اسى في المناطق العشوائية

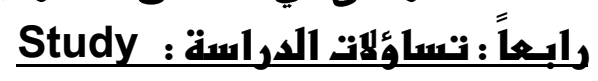

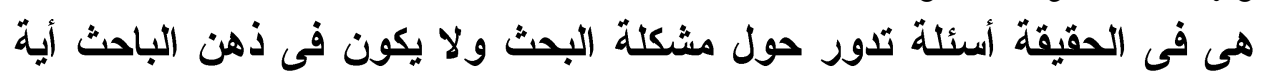

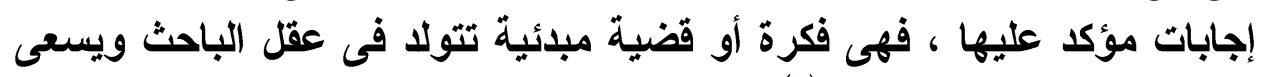
لإثبات صدقها والتحقق منهاب( وتدور هذه الاراسة الراهنة حوات حول مجموعة من التساؤلات التى يمكن صياغتها كالآتى: ونور: ا ـ ماهى ابرز المتغيرات الاجتماعية والاقتصادية التى تميز سكان المناطق

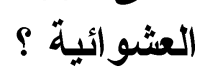

r. إلى اى مدى تسهم الخصائص الاجتماعية والاقتصادية في زيادة

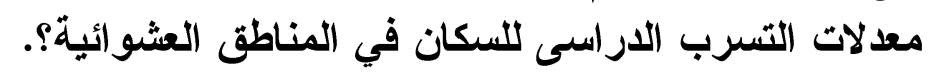

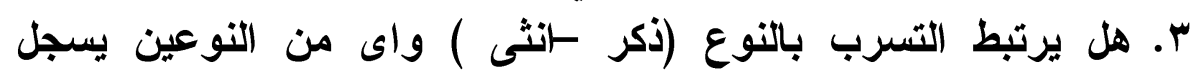

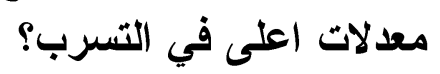

ع. إلى اى مدى تسهم الأوضاع الأيكولوجية التى تحيط بالاطفال التهال المتسربين

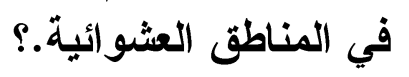
هـ إلى اى مدى تسهم أهم العوامل الاجتماعية والاقتصادية التى تؤثر في

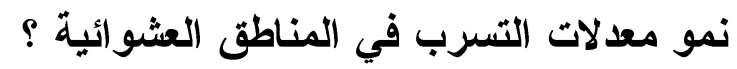

(' ) محمد شفيق. البحث العلمى، الخطوات المنهجية لإعداد البحوث الاجتماعية، الإسكندرية،

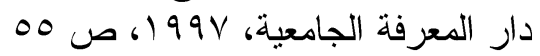


7 ـ إلى اى مدى تسهم الظروف المعيثية المرتبطة بنمو معدلات الامية

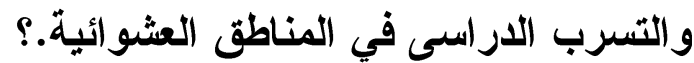

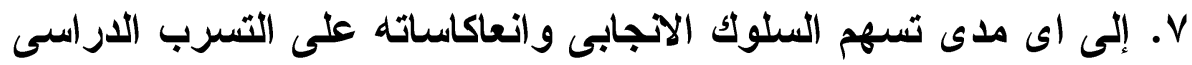

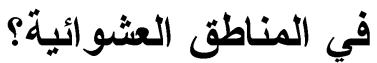

^. الى اى مدى يؤثرحجم الاسرة في زيادة معدل تسرب التلاميذ

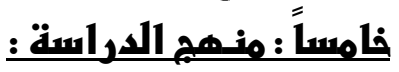

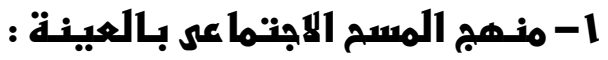

وهو من المناهج التى تسعى إلى وصف وتحليل الظاهرة أو المجتمع المدروس المداف

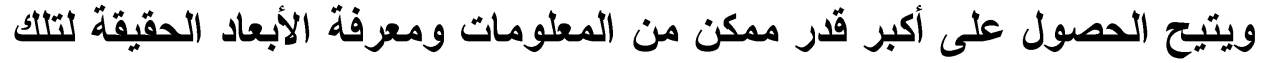

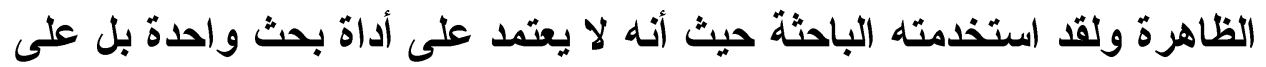

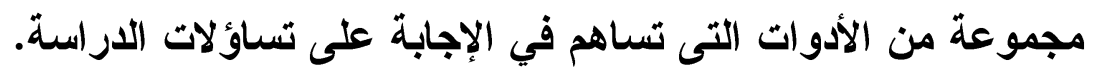

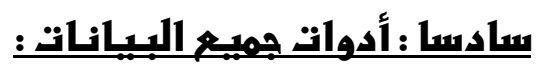

هناك بعض الاعتبارات التى يجب على الباحث أن يضعها فى حسبانه عند

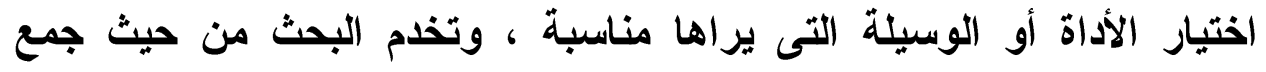

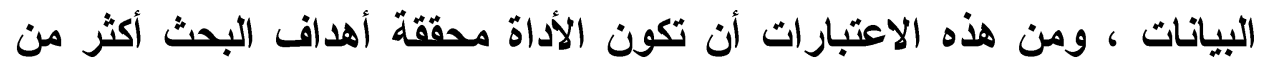

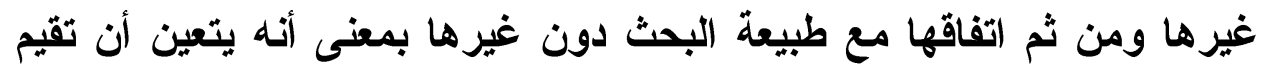
الأدوات المختلفة لجمع البيانات فى ضوه ومن كفاعتها فى الوظيفة التى أختيرت

كها. (1)

ومن الأدوات التى استعاتت بها الباحثة :

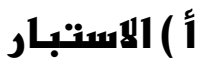

الاستبار هى وسيلة هامة فى جمع البيانات من المبحوثين ، وذلك عن طريق

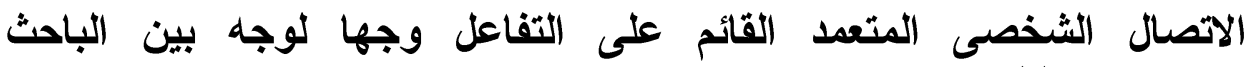

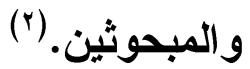

ولقد تم الاعتماد على صحيفة الاستبار كأداة رئيسية لجمع البيانات المطلوبة

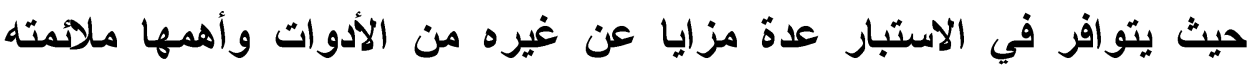
لأهداف البحث ومجتمع البحث الأى يتميز بانخفاض مستوى التعلئ عئ لأفراده

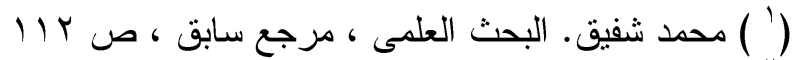

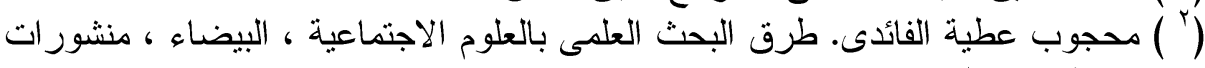

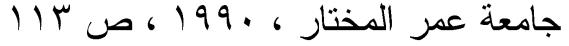




\section{العشوائيات ونمو معدلات الامية والتسرب الدراسى دراسة ميدانية في منطقة عشوائية بمدينة سوهاج}

و إمكانات الباحثة، كما يتميز أيضاً بسهولة معالجة وتحليل بياناته ويتيح فرصة

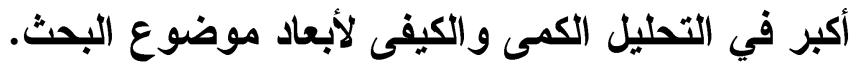

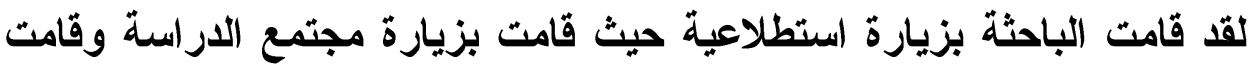
بمعايشة أفراد المجتمع وملاحظة المظاهر العمرانية وطرق الحئه المياة ومظاهرها

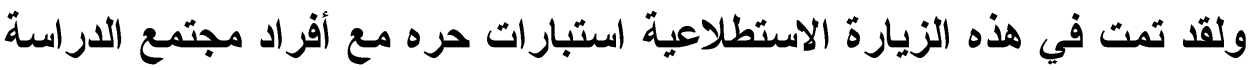
بهدف تكوين إطار موضوعى ونموذج تصورى ميدانى يساعد الباحثة في تصميمٍ أداة الدر اسةة.

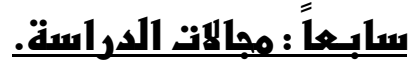
المجال البشرى :

ويتمثل في مجموعة الأفراد الأين ستجرى عليهم الاراسة ويتضمن المجال

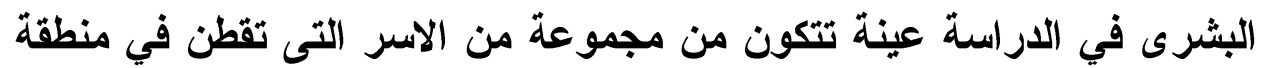

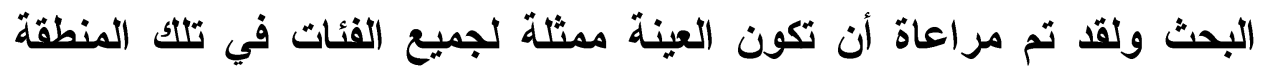
بالإضافة إلى خمس حالات تم تطبيق منهج در استة الحالة عليهم.

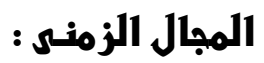

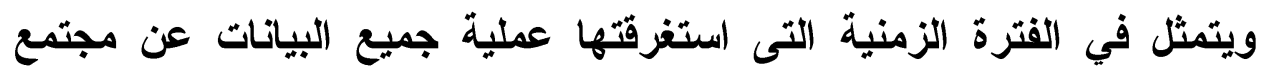

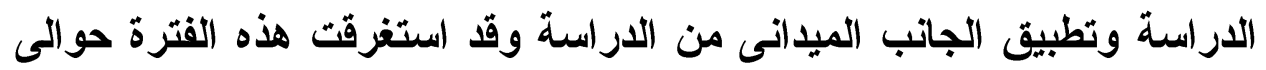

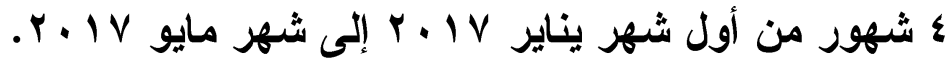
المجال الجغرافهر :

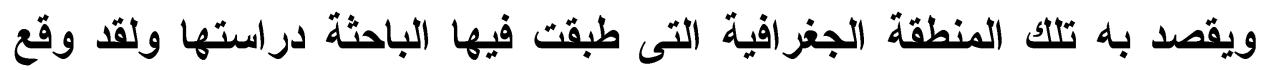

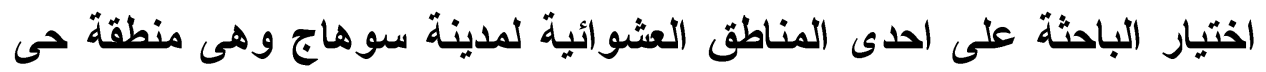
غرب بمدينة سوهاج

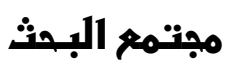

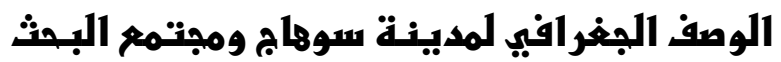

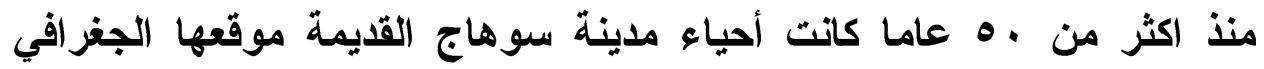

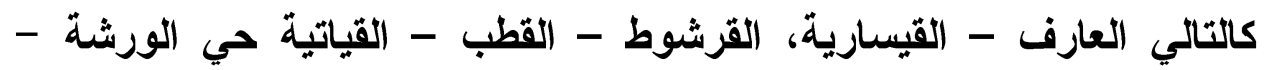
و.......

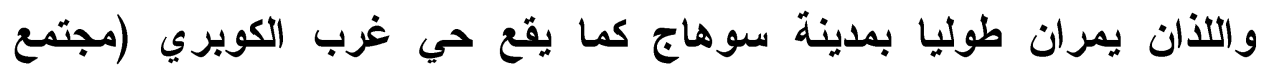

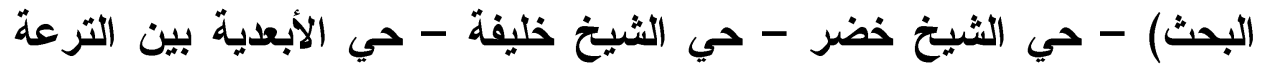
الجرجاوية والترعة السوهاجية والتي تتبع من مدينة سوهاج والجدير الجير بالأكر لين 
أن مدافن مدينة سوهاج تقع غرب الترعة الجرجاوية في حي غرب الكوبري،

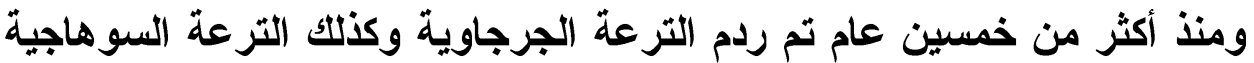
وزادت الكتلة السكنية لمدينة سوهاج وأقيمت مباني ردم على أرض التر الترعة الجرجاوية والسوهاجية غرب نهر النيل، كم أدى أنشاء كوبري أخميم على مئى

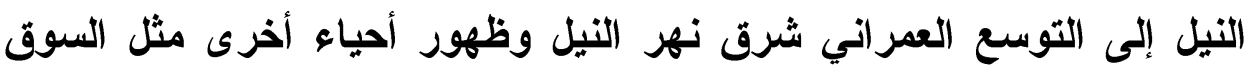

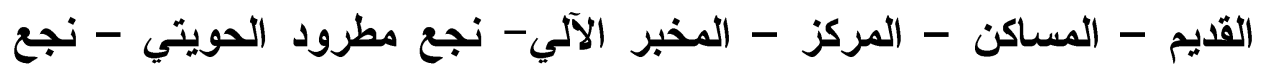

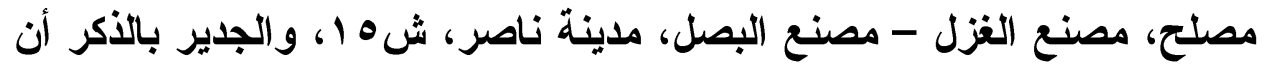

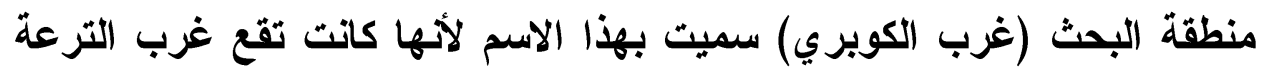

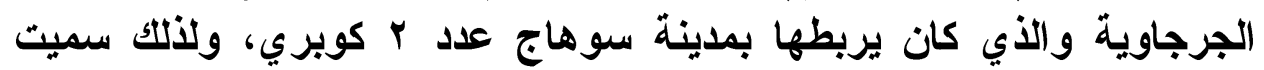

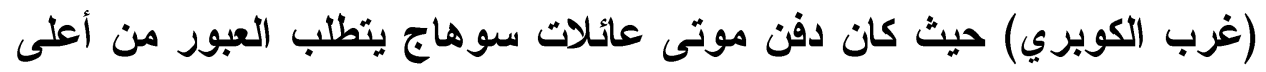

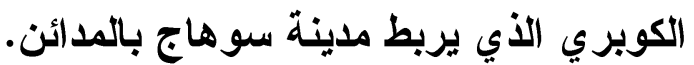

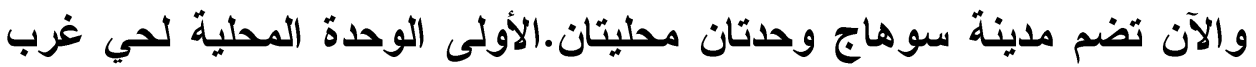

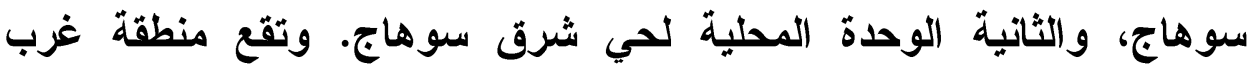

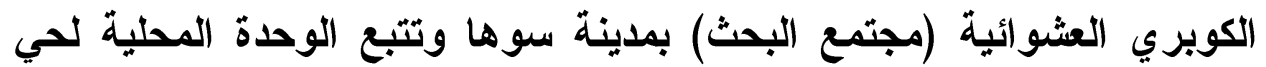

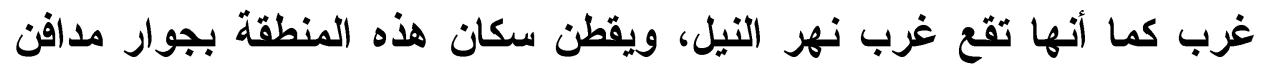

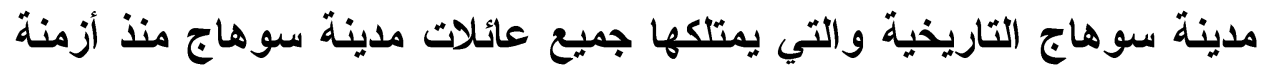

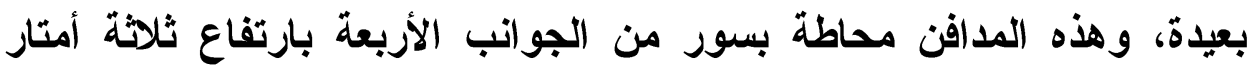

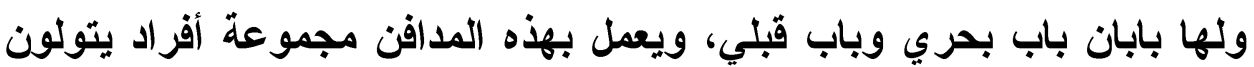
دفن الموتى وهم من عائلة واحدة يتوارثي فياب وند هذه المهنة من الأجداد وحتى الآن

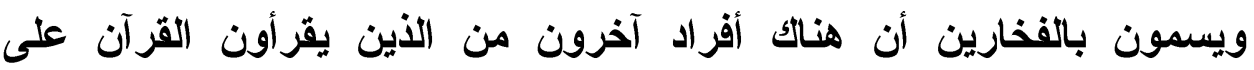

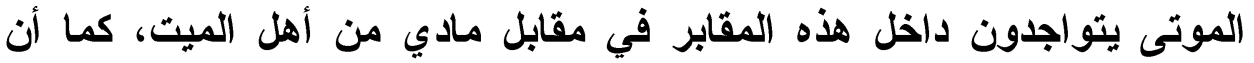

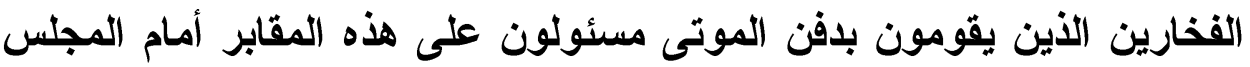

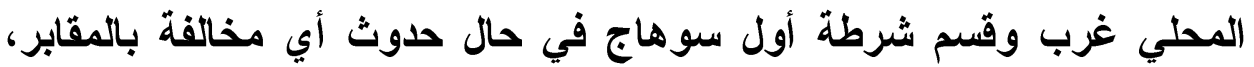

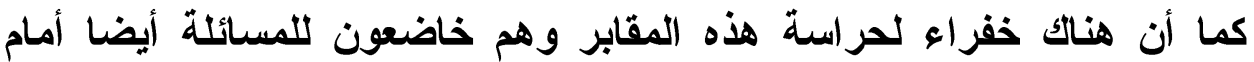

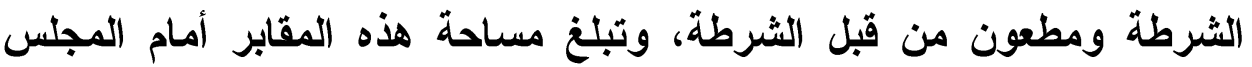

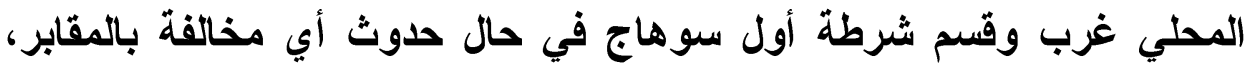

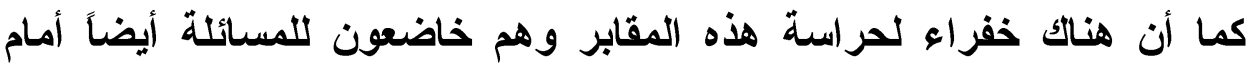

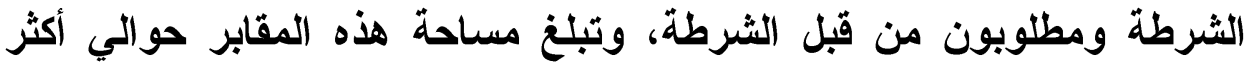

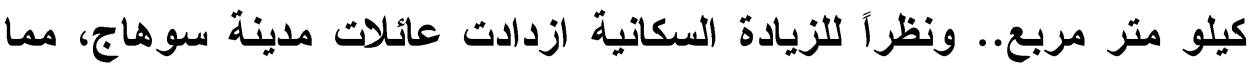


ساعد على ظهور أزمة في امتلاك مقابر لتبلك العائلات، ولمواجهة هذه الأزمة قامت الوحدة المحلية لحي غرب سوهاج بتخصيص قطعة أرض بنفس مساحة

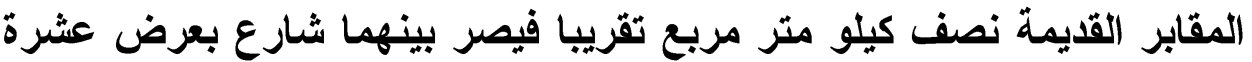

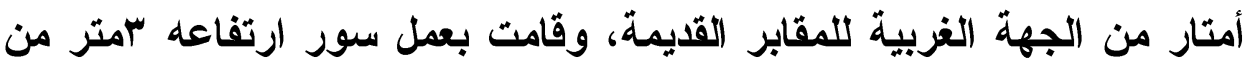

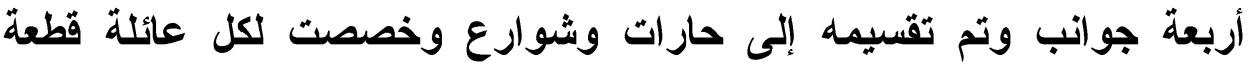

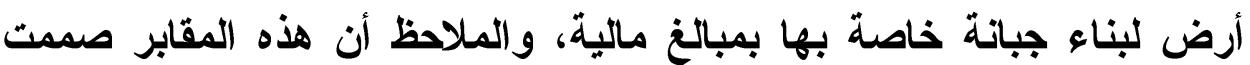

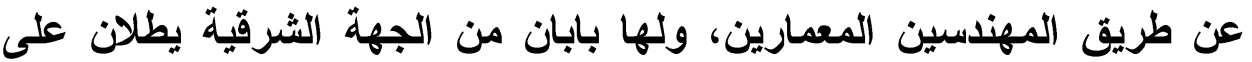

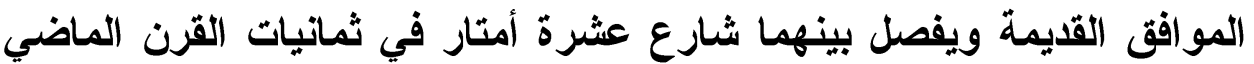
والأي ساعد على التوسع في إنشاء مقابر أخرى غرب المقابر القديمة التهار، كاتت

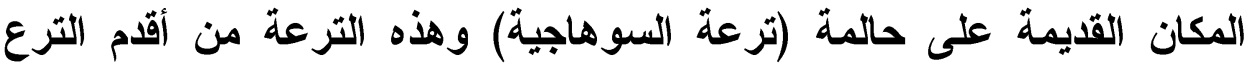

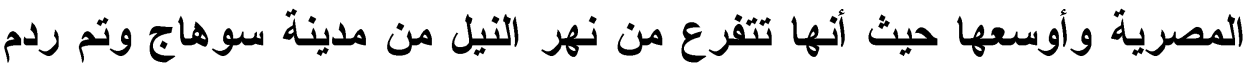

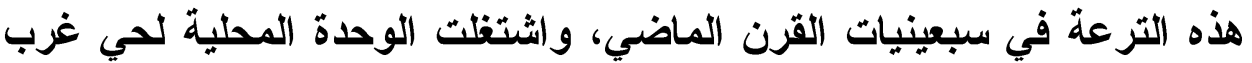

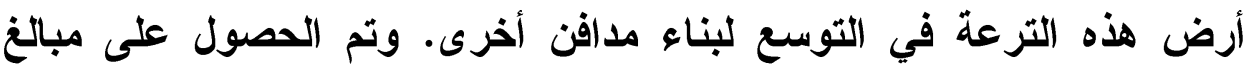

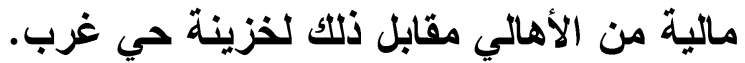

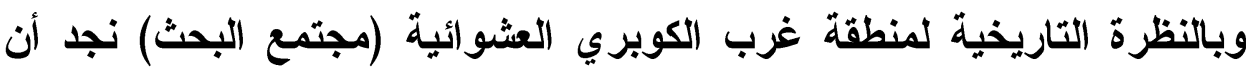

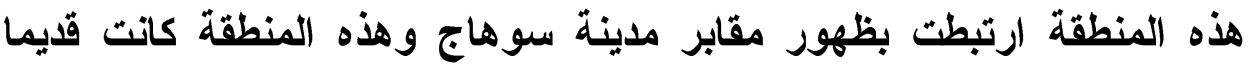

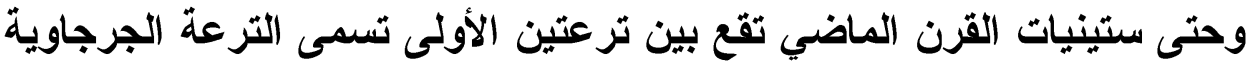

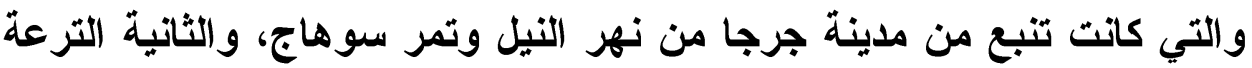
السوهاجية والتي تنبع من مدينة سوهاج وتقريز من نهر النيل، وهذه منانه المنطقة

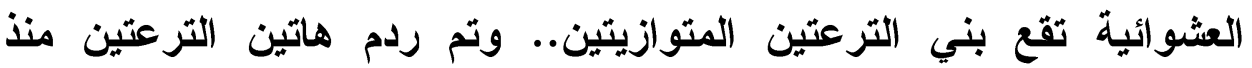

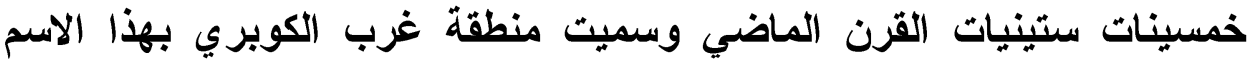

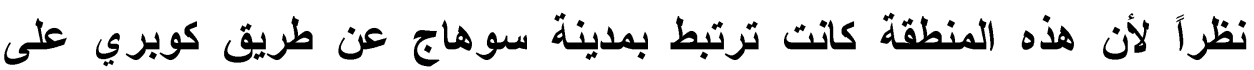
الترعة الجرجاوية والتي تقع غرب مدينة سوهاج وتفصل بين منطقة المقاعد

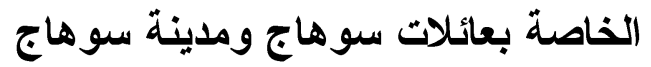

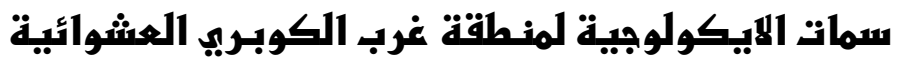
ارتبط تكوين تلك المنطقة العشوائية في مدينة سوهاج بوجود المقابر قديما وحديثا، لقد كاتت المقابر غير مرغوبة في السكن إلا من الطبقات الدنيا الفقيرة

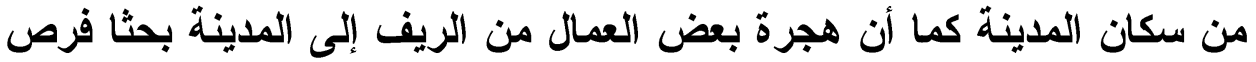

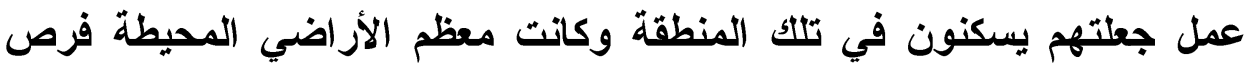


عمل جعلتهم يسكنون في تلك المنطقة وكاتت معظم الأراضي المحيطة بالمقابر

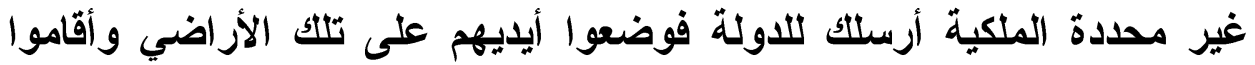

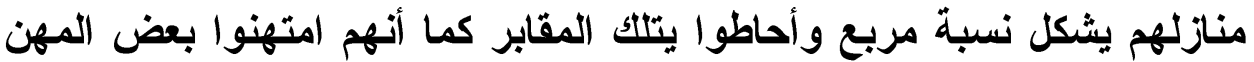

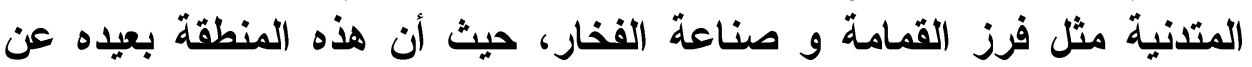

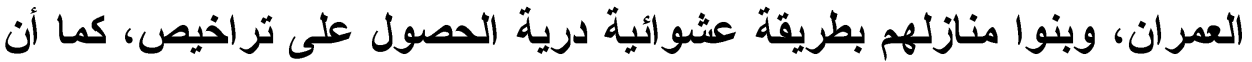

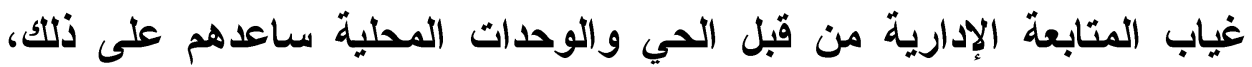

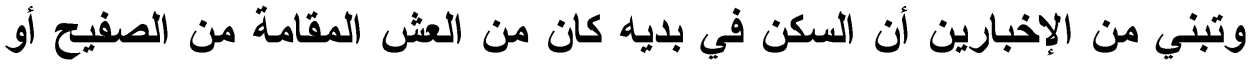

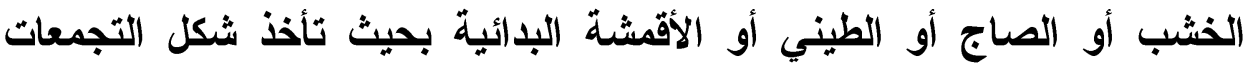

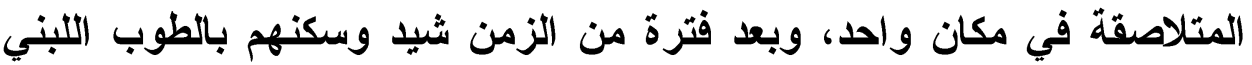

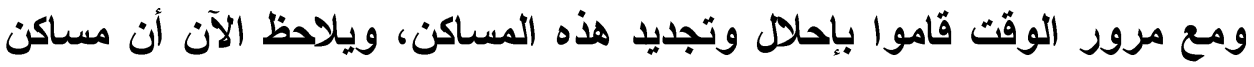

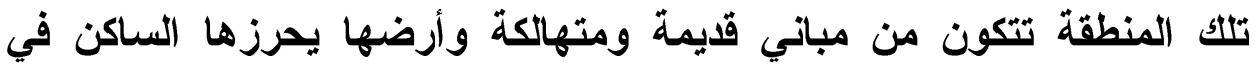

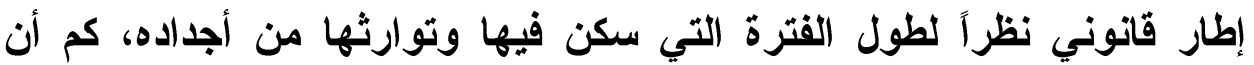

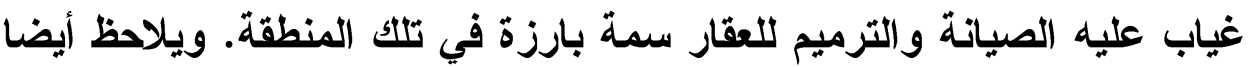

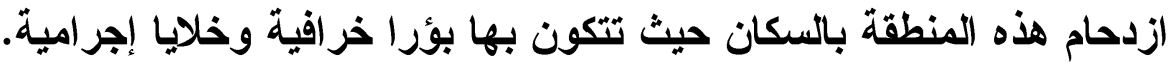

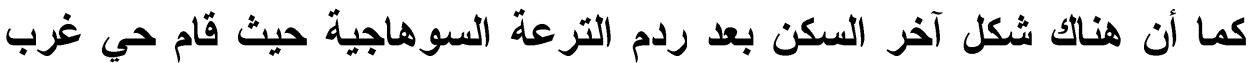

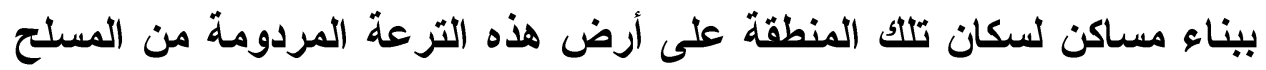

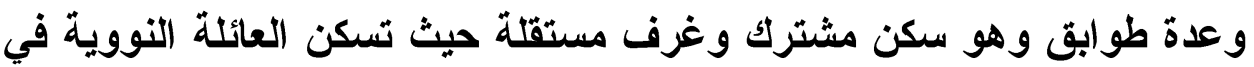

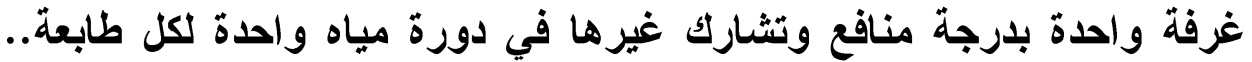

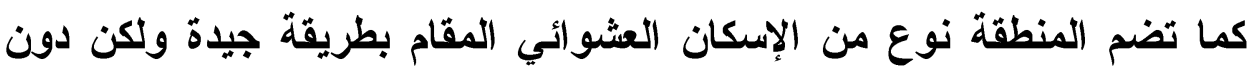

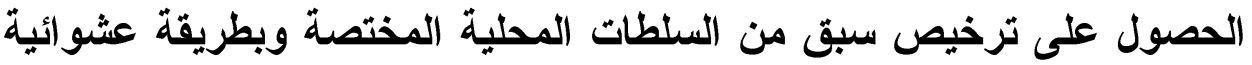

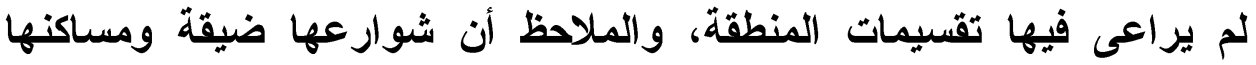

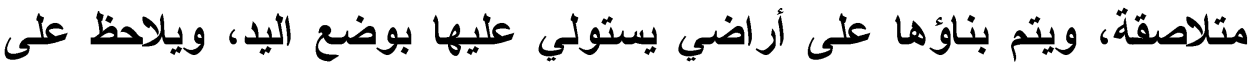

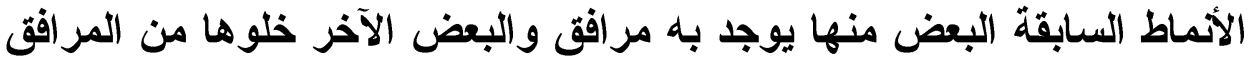

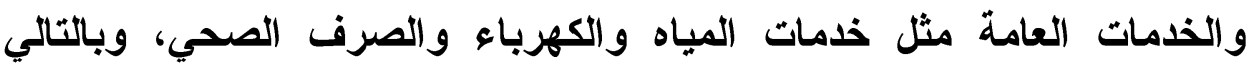

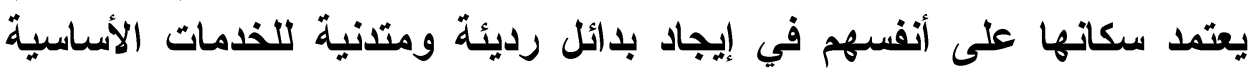
التي يحتاجون إليها في حياتهم اليومية. 


\section{الببيانات الميدانية:}

\begin{tabular}{|c|c|c|}
\hline النسبة المئوية & التكر ار & الفئة العمرية \\
\hline- & - & \\
\hline $\mathrm{V}$ & IV & من · r - اقل من · r سنة \\
\hline rA & $V$. & من · r - اقل من ، ع سنة \\
\hline ro & $4 \pi$ & من · ع -اقلمن ، 0 سنة \\
\hline 11 & $\varepsilon 0$ & من · هالى اقل من هـ \\
\hline Ir & $r$ & من ه0_اقل من · \\
\hline 7 & 10 & من • 7 الحى اقل من ه 7 \\
\hline$\varepsilon$ & 1. & هاسنة فأكثر \\
\hline$\% 1 \ldots$ & Yo. & الجملة \\
\hline
\end{tabular}

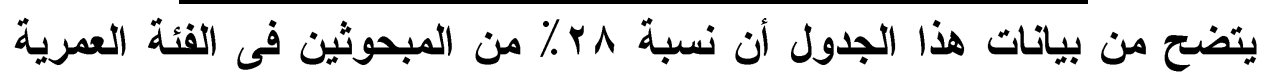

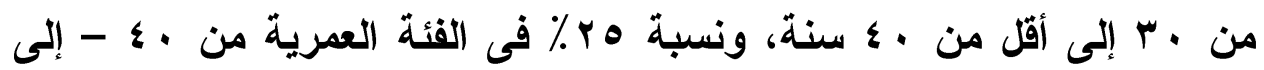

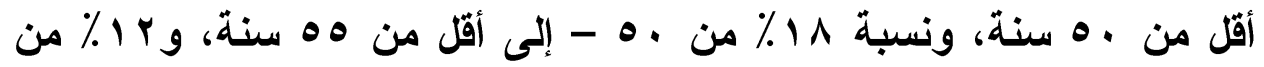

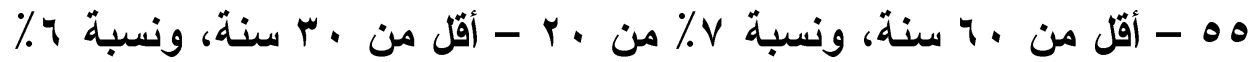

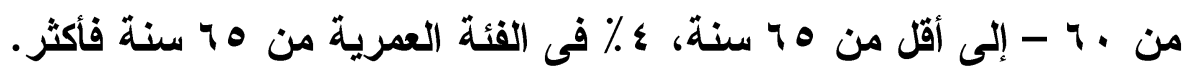

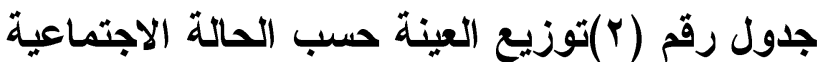

\begin{tabular}{|c|c|c|c|c|c|}
\hline الجملة & مطلق & أرمل & مثزوج & غير متزوج & \\
\hline ro. & $\Lambda$ & 0 & TrV & -- & التكر ار \\
\hline$\% 1 \ldots$ & $r$ & $r$ & 90 & -- & النسبة المئوية \\
\hline
\end{tabular}

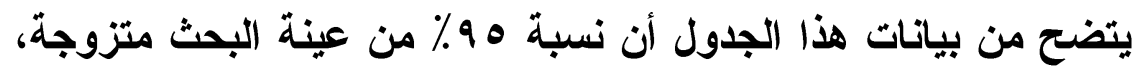

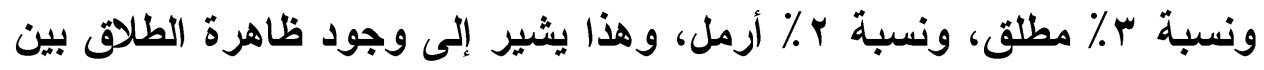

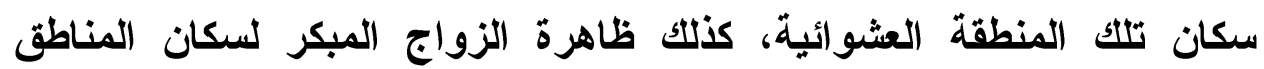
العثو ائية. 
جدول رقم (r) الحالة التعليمية

\begin{tabular}{|c|c|c|}
\hline النسبة المئوية & التكر ار & الاستجابة \\
\hline$\% \varepsilon r$ & $1 \cdot 1$ & أمي \\
\hline$r \mu$ & $\Lambda Y$ & تقرأ وتكتب \\
\hline 10 & $r \wedge$ & مؤهل أقلّ من متوسط \\
\hline 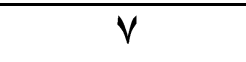 & IV & مؤهل متوسط \\
\hline$r$ & 0 & مؤهل فوق متوسط \\
\hline$\% 1 \ldots$ & ro. & الجملة \\
\hline
\end{tabular}

إن مستوى تعليم الفرد ومدى تأثره بوسائل الإعلام المختلفة ، وكيفية تعامله

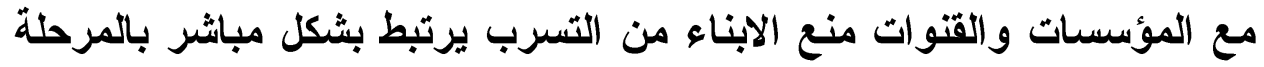
العمرية التى وصل الأليهات وفئات

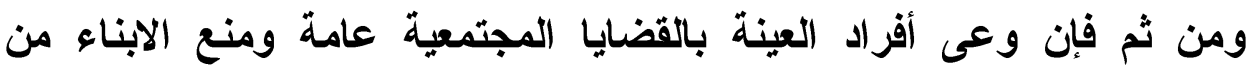

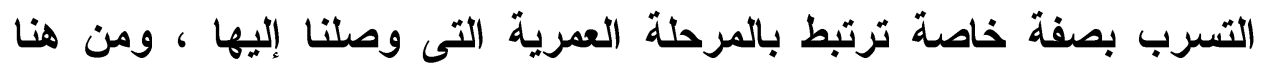

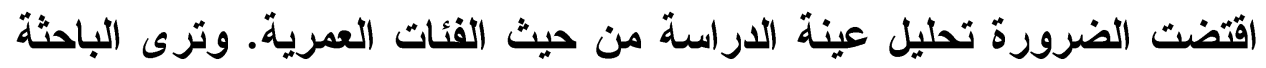

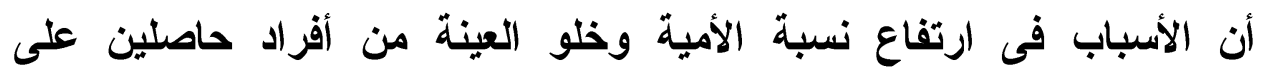

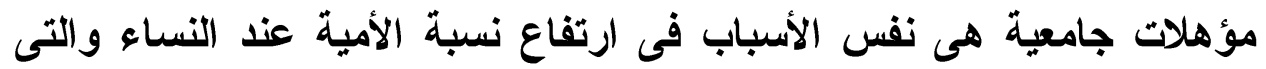

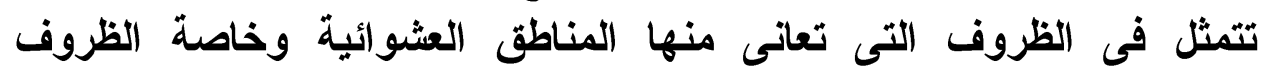

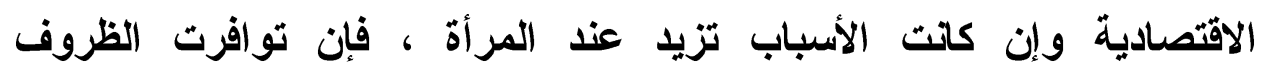
الاقتصادية لرب الأسرة يفضل تعليم الأكر عن الأثثى وهذا يتضح من وفئل وجود

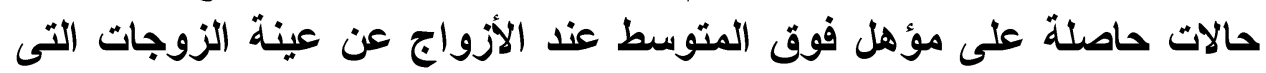

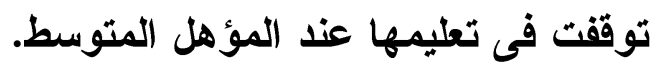

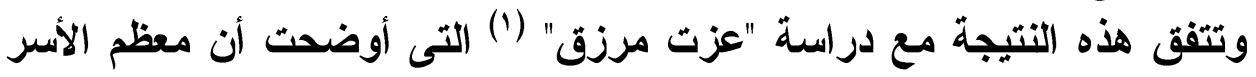

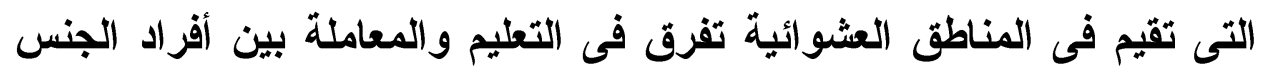

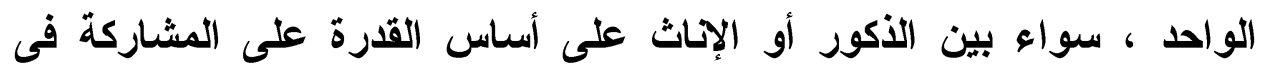
مسئوليات الأسرة.

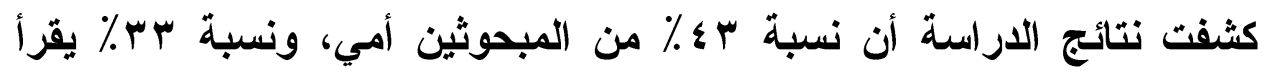

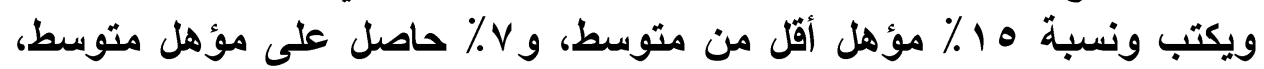

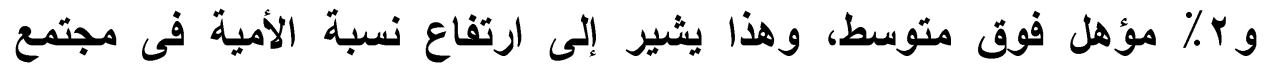

( ') عزت مرزق فهيم. أساليب التشئة الاجتماعية و علاقتها بالسلوك الانحر افى. مرجع سابق 
البحث، وأيضاً يشير إلى تلنى المستوى التعليمى لسكان منطقة غرب الكوبرى

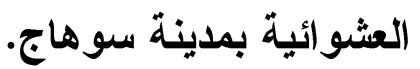

جدول رقم (ع)توزيع عينة الار اسنة حسب المهنة

\begin{tabular}{|c|c|c|}
\hline النسبة المئوية & التكرار & |لاستجابة \\
\hline Ir & $r \cdot$ & عامل أجرى \\
\hline $\mathrm{V}$ & 11 & موظف حكومة \\
\hline$\Lambda$ & $r \cdot$ & بائع متجول \\
\hline 9 & rr & سائق سيارة \\
\hline Ir & $r r$ & سمكرى سيار ات \\
\hline$r \cdot$ & 0. & يعمل في مهنة الجزارة \\
\hline$r q$ & 70 & عربجى \\
\hline$r$ & 0 & ماستح احذية \\
\hline$r$ & 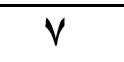 & جامـع قمامة \\
\hline$\% 1 \ldots$ & ro. & الجملة \\
\hline
\end{tabular}

كشفت نتائج الاراسة أن سكن منطقة غرب الكوبرى العشوائية بمدينة سوهاج

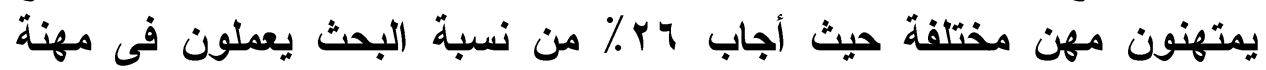

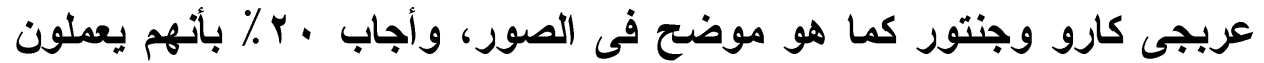

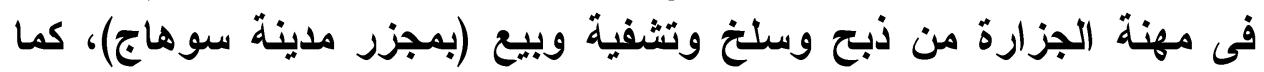

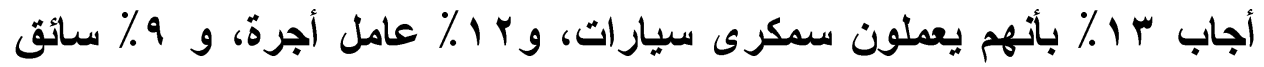

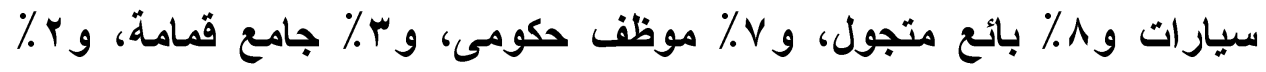

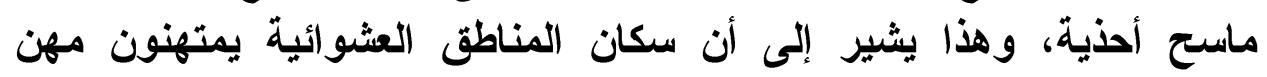
متدنية. مائ.

كما يتضح من الجدول السابق أن سكان تلك المناطق ليسوا منتجين أساسيين ،

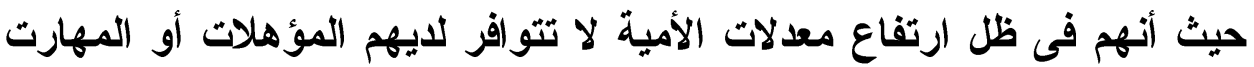

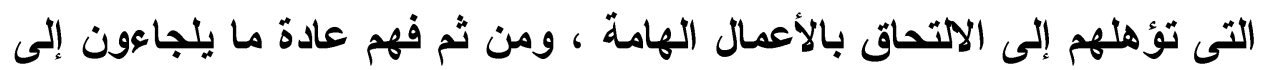

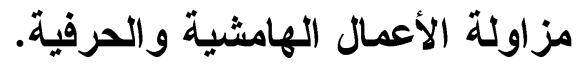


مجلة كلية الآداب، جامعة سوهاج، العدد السادس والأربعون، الجزء الأول، يناير 1 I • Yم

جدول رقم (0) يبين الحالة التعليمية للزوجة

\begin{tabular}{|c|c|c|}
\hline النسبة المئوية & التكرار & الاستجابة \\
\hline Vo & $1 \wedge \Lambda$ & أمية \\
\hline 10 & $r \wedge$ & تقرأ وتكتب \\
\hline$v$ & $1 \mathrm{~V}$ & مؤهل أقل من متوسط \\
\hline$r$ & $V$ & مؤهل متوسط \\
\hline$\% 1 \ldots$ & ro. & الجملة \\
\hline
\end{tabular}

كثفت نتائج الاراسة أن الحالة التعليمية لزوجات سكان منطقة غرب الكوبرى

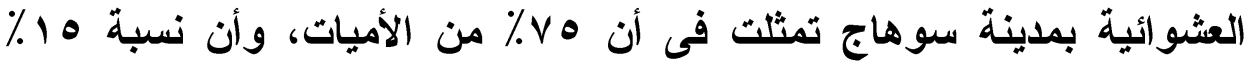

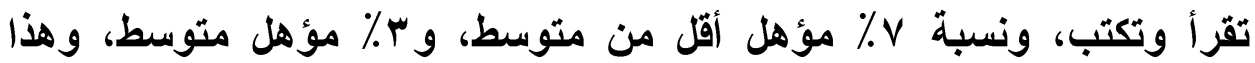

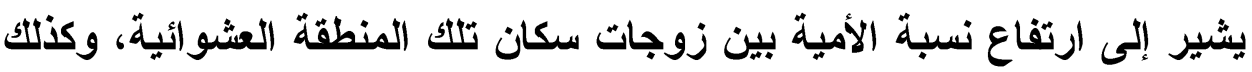
عدم الاهتمام بتعليم الأثاث. وترجع الباحثة ارتفاع نسبة الأمية بين السيدات فى المنطقة العثوائية نتيجة الظروف الصعبة التى تعانى منها المنطقة والتى تنعكس بالضرورة التهله على المرأة أثة

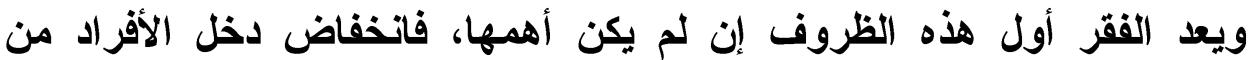

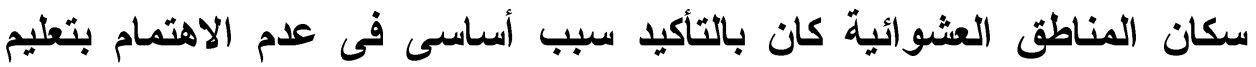
الأبناء وخاصة الإناث أو محاولة الحصول على على مؤهل أعلى من لن المؤهل المتوسط نتيجة لعدم القدرة على متطلبات ونفقات الإن التعليم. وترى الباحثة أن انخفاض المستوى التعليمى للمرأة يعد من أهم الأسباب

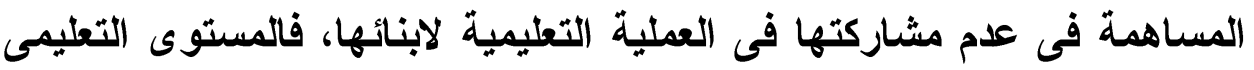

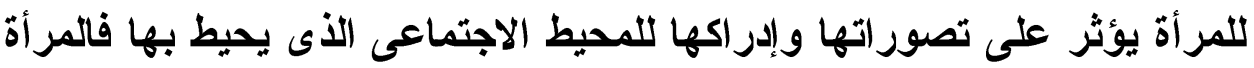
المتعلمة أكثر وعياً وإدراكاً بتأثير الحكومة على على حياتها كما أنها أكثر كفاعة من

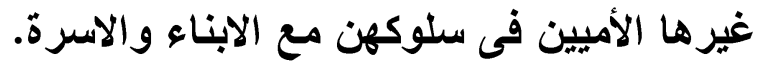

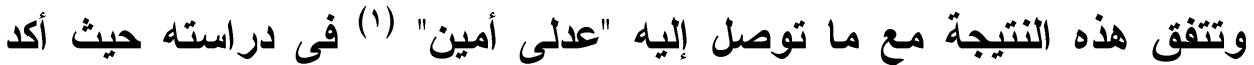

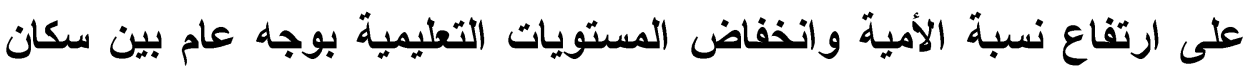
المناطق العثوائية.

(' ) عدلى أمين أحمد. المشاركة السياسية لسكان المناطق العشو ائية. مرجع سابق. 
جدول رقم (؟) الحالة المهنية للزوجة

\begin{tabular}{|c|c|c|c|c|c|c|c|}
\hline الجملة & تسول & للمحنيلات & سائعة شاى في المدينة & تومرجية & مكومى & منزل & المهنة \\
\hline ro. & $r \bar{r}$ & $r v$ & $r r$ & $r$. & $\Lambda$ & $T r$. & التكرار \\
\hline$\% 1 \ldots$ & 14 & 10 & 9 & Ir & $r$ & $\varepsilon \wedge$ & المئوية \\
\hline
\end{tabular}

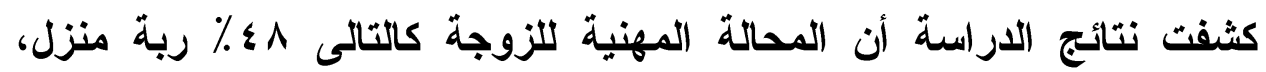

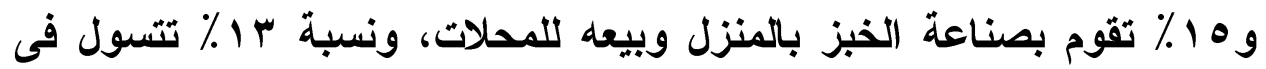

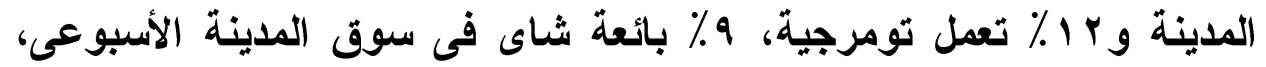

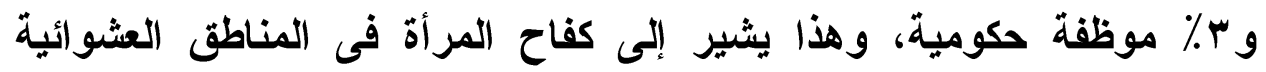

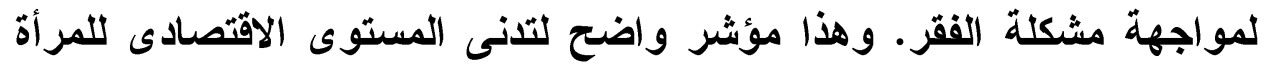

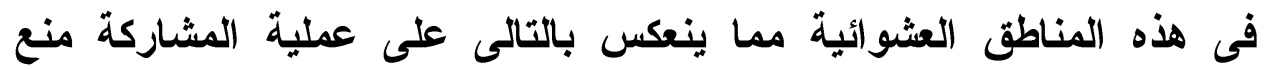

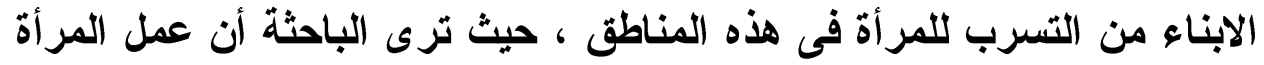

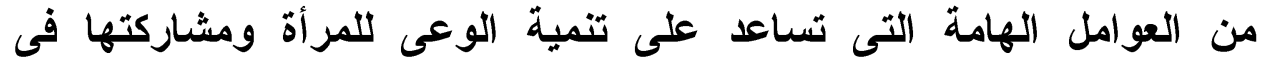

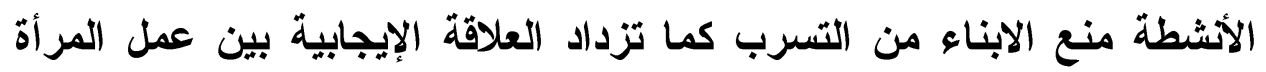

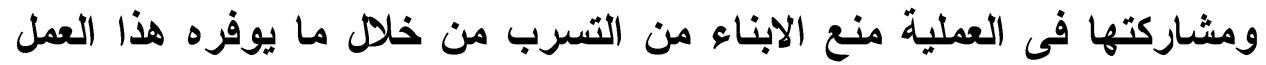

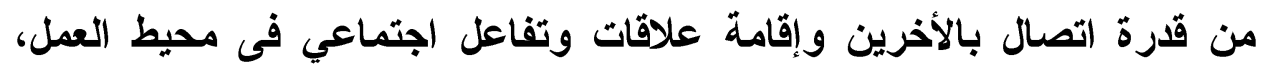

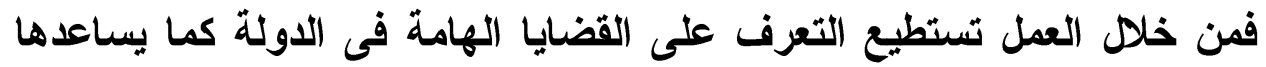

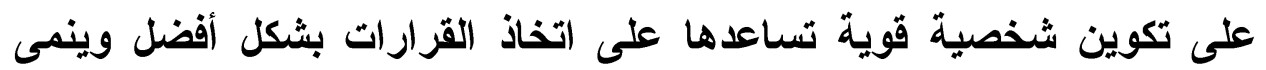

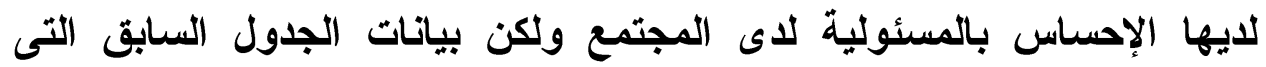

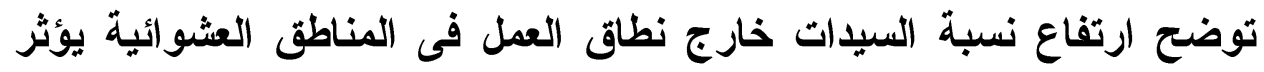

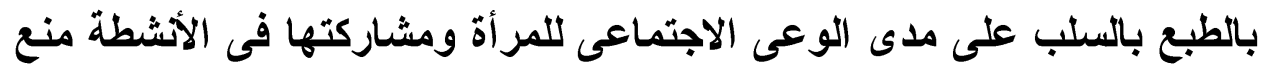
الابناء من التس بلت علئ

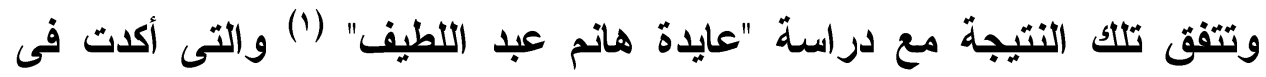
دراستها على انخفاض نسبة المبحوثات اللالتى يعملن خارج المنزل لماند لمساعدة

(') (') عايدة هانم عبد اللطيف. احتياجات ومشكلات المر أة فى العشو ائيات. مرجع سابق 
مجلة كلية الآداب، جامعة سوهاج، العدد السادس والأربعون، الجزء الأول، يناير 1 I • بم

الأزواج وذلك على الرغم من ارتفاع معدلات الفقر وكبر حجم الأسرة فى عينة الار اسةة. جدول رقم (V) يبين توزيع العينة وفق نوع السكن

\begin{tabular}{|c|c|c|}
\hline النسبة المئوية & التكرار & الاستجابة \\
\hline$r \varepsilon$ & A० & شقة مستقلة \\
\hline IT & rr & منزل من بابه \\
\hline$\theta$ & Ir & عشه \\
\hline rq & $9 \wedge$ & حجرة واحدة ودورة مياه مشتركة (سكن حكومى) \\
\hline 9 & $r r$ & حوش وأوضة \\
\hline$\% 1 \cdots$ & ro. & الجملة - الة \\
\hline
\end{tabular}

كشفت نتائج الارسة عن توزيع العينة وفق نوع السكن، حيث تبين أن نسبة

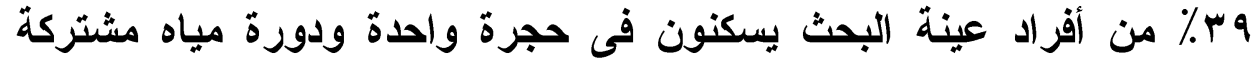

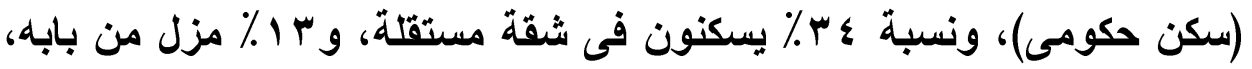

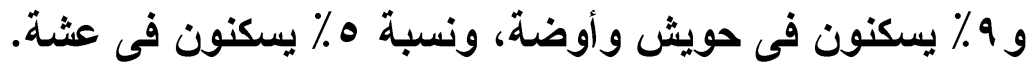
جدول رقم (^) يبين عدد حجرات واتهبه المسكن

\begin{tabular}{|c|c|c|}
\hline النسبة المئوية & التكر ار & الاستجابة \\
\hline$r q$ & 91 & حجرة واحدة \\
\hline rq & VY & حجرتين \\
\hline IV & $\varepsilon r$ & ثلاث حجر ات \\
\hline 1. & Y & حوش واوضة \\
\hline 0 & $1 \%$ & عشة \\
\hline$\%$ & ro. & الجملة \\
\hline
\end{tabular}

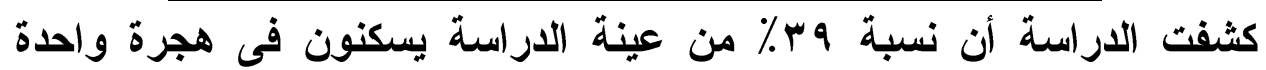

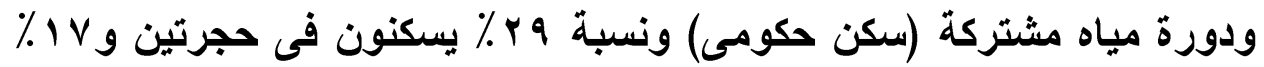

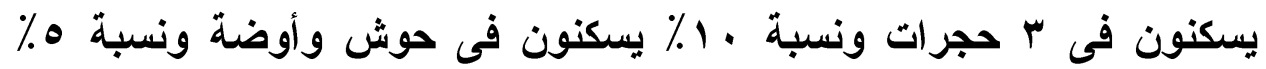

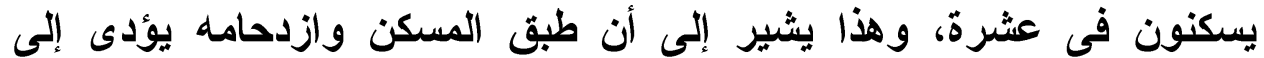

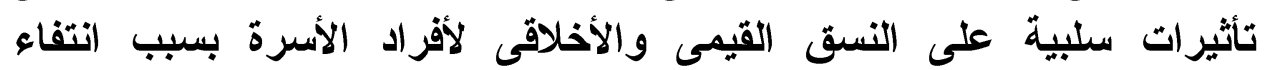
الخصوصية. 
العشوائيات ونمو معدلات الامية والتسرب الدراسى دراسة ميدانية في منطقة عشوائية بمدينة سوهاج

جدول رقم(9) بين مستوى الازدحام داخل الحجرة

\begin{tabular}{|c|c|c|c|c|c|c|}
\hline & 7 & $\bullet$ & $\varepsilon$ & $r$ & $\bar{Y}$ & العدد \\
\hline ro. & 0. & 11. & $\varepsilon r$ & $r$ & 11 & عدد الأبناء فى حجرة واحدة \\
\hline$\%$ & $r$. & $\varepsilon \varepsilon$ & IV & Ir & $\mathrm{V}$ & النسبية المئوية \\
\hline
\end{tabular}

كشفت الدراسة من أن مستوى الازدحام داخل الحجرة تمثل فى أن ؟ ؛ ٪ أجابوا

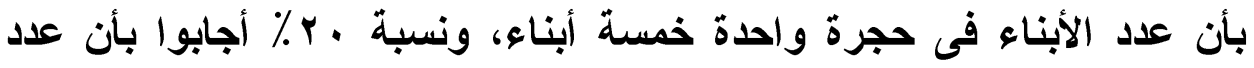

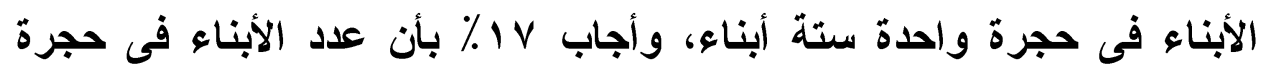

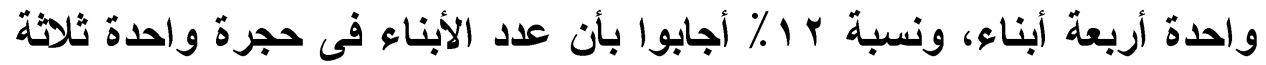

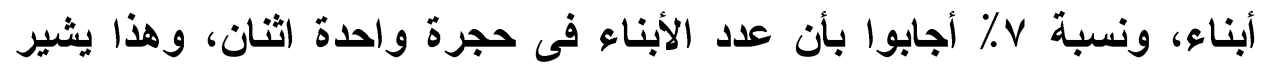

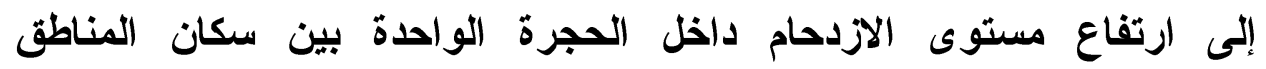

العثوائية.

جدول رقم ( م إيبين كيفية المعيشة في حجرة واحدة

\begin{tabular}{|c|c|c|c|c|c|c|c|c|c|c|}
\hline \multirow[t]{2}{*}{ النسبة } & \multirow{2}{*}{ ع } & \multicolumn{2}{|c|}{ فى الشارع } & \multicolumn{2}{|c|}{ فى الحوش } & \multicolumn{2}{|c|}{ فى الطرقة } & \multicolumn{2}{|c|}{ فلى نفس } & \multirow{2}{*}{ الطكان } \\
\hline & & $\% 1 \wedge$ & $r \varepsilon$ & $\% 11$ & $r \varepsilon$ & $\%$ or & $v$. & $\% 1 r$ & 17 & \\
\hline & E & $\% 10$ & $r$. & $\% 11$ & T $\varepsilon$ & $\%$. V & 9. & & - & الغكبل \\
\hline & E & $\%$ \% & 11 & $\% 11$ & Y $\varepsilon$ & $\%$ \%. & $q r$ & & - & مكان نشر نشابس \\
\hline & Ir & $\% 9$ & ir & $\% 11$ & $r \varepsilon$ & $\%$ \%.० & $\varepsilon 9$ & $\%$ r. & $\leqslant 9$ & مذاكرة \\
\hline
\end{tabular}

يوضح هذا الجدول كيفية المعيشة فى حجرة واحدة من وجهة نظر المبحوثين

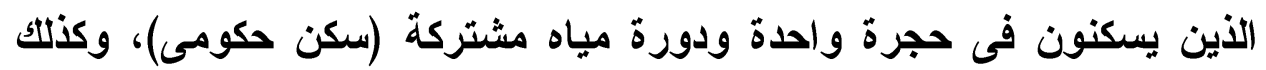

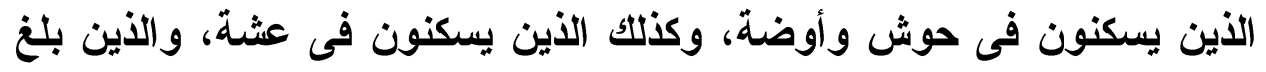
تعدادهم ع ب ا مبحوث من جملة العينة، وكاتت إجاباتهم كالتالى. وكن. 


\begin{tabular}{|c|c|c|}
\hline النسبة المئوية & التكر ار & الاستجابة \\
\hline Ir & $r r$ & بوضع اليد \\
\hline$r$ & $\mathrm{~V}$ & تم شر ائهل من واضع با \\
\hline $\mathrm{V}$ & 11 & تم شر ائه من الحكومة \\
\hline$r$ & 0 & تم شر ائه من مالك \\
\hline or & Irr & | ايجار \\
\hline rY & 00 & موروث من الجدود \\
\hline$\%$ & YO. & الجملة \\
\hline
\end{tabular}

بالنسبة لملكية السكن كثفت نتائج الدراسة أن به \% كم سكان منطقة غرب

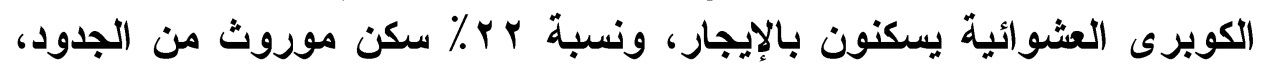

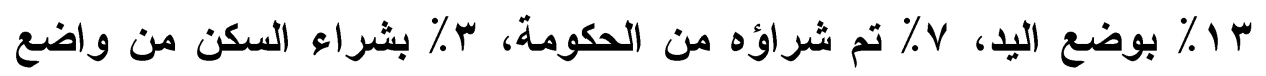
اليلا، Y \% تم شر اعه من مالكك.

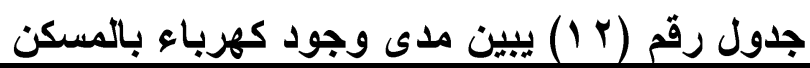

\begin{tabular}{|c|c|c|c|}
\hline الجملة & ע & نعم & الاستجابة \\
\hline TO. & $\leqslant 0$ & $r .0$ & التكر ار \\
\hline$\% 1$. & 11 & $\Lambda r$ & النسبة المئوية \\
\hline
\end{tabular}

كشفت الاراسة أن r r\% من العينة أجابوا بأنه يوجد كهرباء بالمسكن، بينما

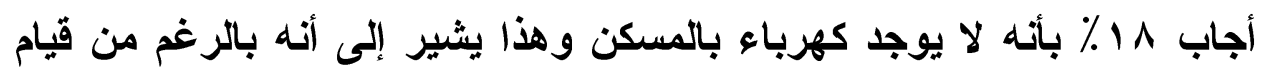

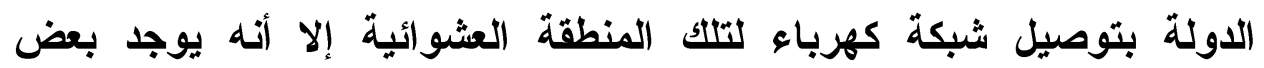

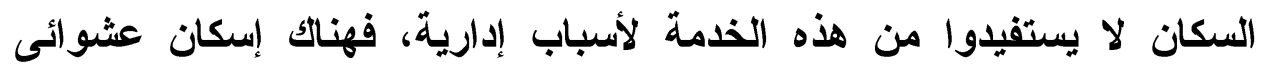

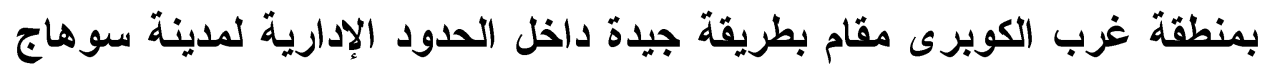

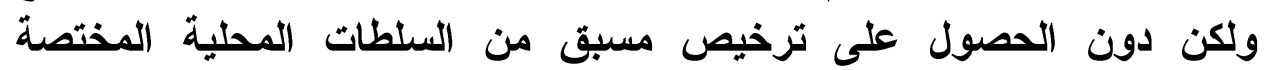
وبطريقة عشوائية لم ير اعى فيها تقلى تُشيمات المنطقة. 


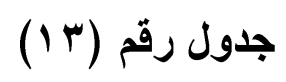

يبين كيفية الإضاعة حال عدم وجود عداد كهرباء

\begin{tabular}{|c|c|c|c|c|}
\hline الجملة & توصيلة من الشارع & توصيلة كهرباء من & لمبة جاز & المتغير \\
\hline$\leqslant 0$ & rA & Tr & 0 & التكر ار \\
\hline$\% 1 \ldots$ & TY & TV & 11 & النسبة المئوية \\
\hline
\end{tabular}

يبين هذا الجدول كيفية الإضاعة حال عدم وجود عداد كهرباء بالمسكن حيث الثائ

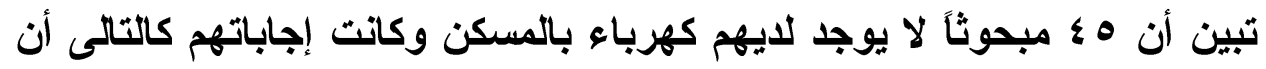

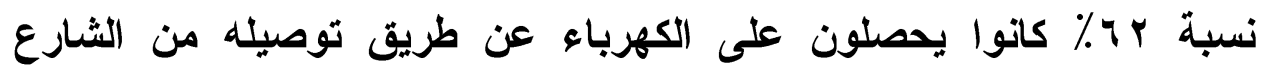

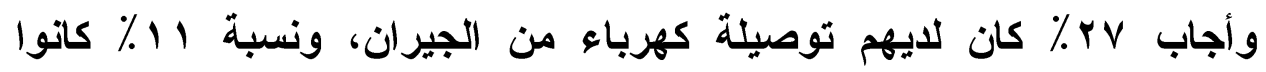
يستخدمون لمبة جاز للإضاءة.

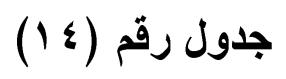

\begin{tabular}{|c|c|c|c|}
\hline & $y$ & ن نعم & \\
\hline ro. & $\Lambda$ & $r \leqslant Y$ & التكر ار \\
\hline$\% 1 \ldots$ & $r$ & $9 V$ & النسبة المئوية \\
\hline
\end{tabular}

يبين توزيع العينة وفق توافر مياه نقية بالمسكن :

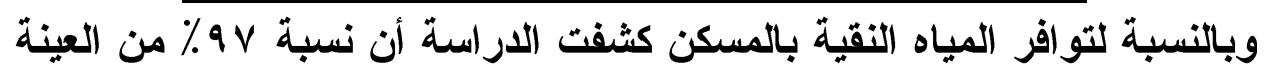

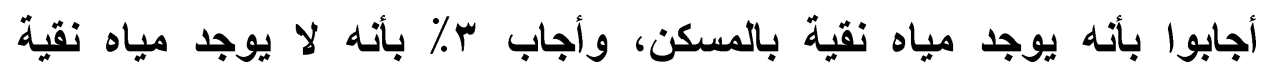

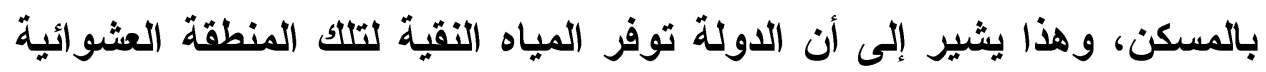
إلا أن نسبة r\% لا يستفيدون من تلك الخدمة لأسباب قد تكون مالية أو إدارية أيضاً.

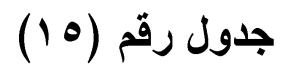

\begin{tabular}{|c|c|c|c|c|}
\hline الجملة & ارتوازية & الشارعة (طلة منبة) & من الجيران & \\
\hline$\Lambda$ & $r$ & $\varepsilon$ & $r$ & التكر ار \\
\hline$\% 1 \ldots$ & ro & 0. & ro & النسبة \\
\hline
\end{tabular}

يبين توزيع العينة وفق مصادر الحصول على الماء

بالنسبة لتوافر المياه النقية من حنفية فى الثارع، واجاب هب ٪ بأنهم كانوا

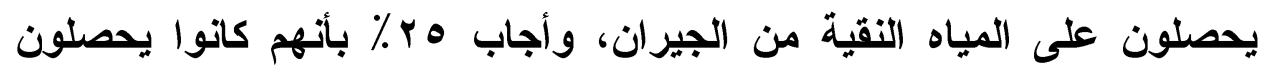
على المياه عن طريق مياه ارتوازية (طلمبة). 
مجلة كلية الآداب، جامعة سوهاج، العدد السادس والأربعون، الجزء الأول، يناير \1 ا بم

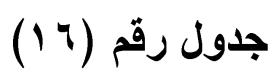

\begin{tabular}{|c|c|c|c|}
\hline الجملة & $y$ & نعم & \\
\hline ro. & 0. & $r \ldots$ & التكر ار \\
\hline$\% 1 \ldots$ & $r$. & $\Lambda$. & النسبة \\
\hline
\end{tabular}

كثفت الدراسة عن أن نسبة ، ^٪ أجابوا بأنه يوجد شبكة صرف صحى بينما

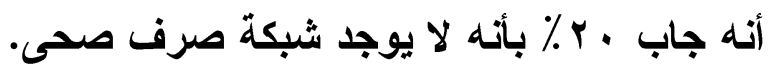

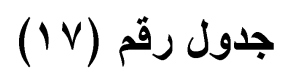

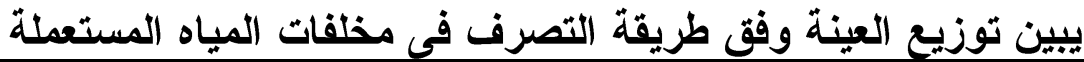

\begin{tabular}{|c|c|c|c|}
\hline الجملة & عن طريق الترنشات & عن طريق الكساحات & \\
\hline 0. & 10 & ro & التكرار \\
\hline$\%$ & $r$. & $\mathrm{V}$. & النسبة \\
\hline
\end{tabular}

وبالنسبة لطريقة التصرف فى مخلفات المياه المستعملة، بينت الاراسة أن

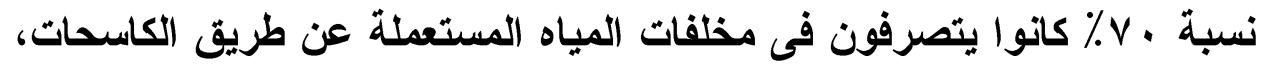
ونسبة ، ب. عن طريق الترنشات.

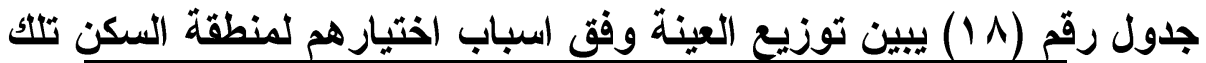

\begin{tabular}{|c|c|c|}
\hline$\%$ & ك & الاستجابة \\
\hline$\varepsilon$. & $1 \ldots$ & السكن هنا رخيص \\
\hline 0 & Ir & قريب من عملى \\
\hline$\varepsilon 0$ & $11 r$ & وجدت أهلى يسكنون هنا \\
\hline 1. & rq & قريبة من المرافق مصدر \\
\hline$\% 1 \ldots$ & ro. & الجملة \\
\hline
\end{tabular}

وبالنسبة لأسباب اختيار المبحوثين لمنطقة السكن كثفت الاراسة أن نسبة

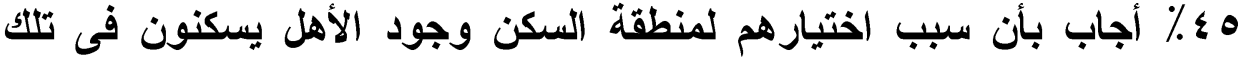

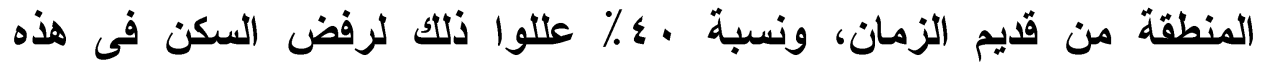

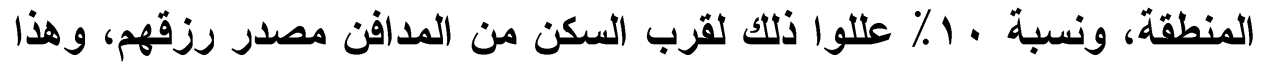
يثير إلى أن منطقة غرب الكوبرى العشوائية يقبل القاطنون بهاب الثها معيشة 


\section{العشوائيات ونمو معدلات الامية والتسرب الدراسى دراسة ميدانية في منطقة عشوائية بمدينة سوهاج}

اجتماعية متدنية بل ويقبلون على النزوح إليها بسبب محدودية إمكانهم

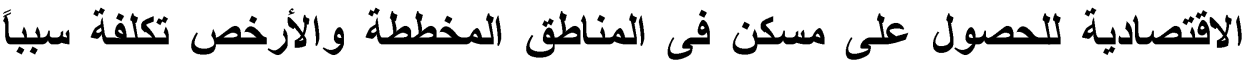

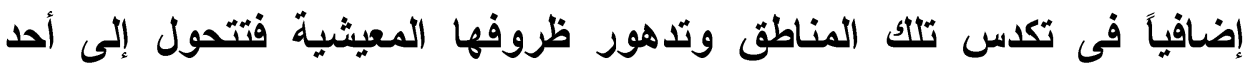
جيوب الفقر مقارنة بالمناطق الحضرية الكبرى.

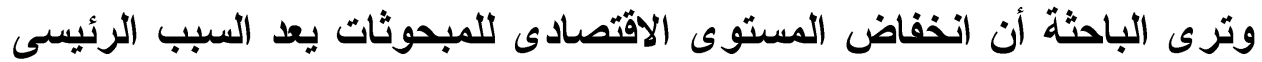

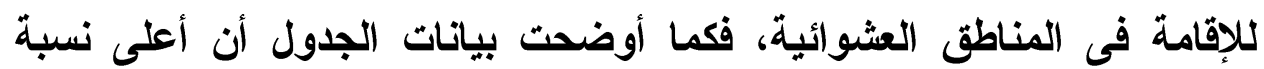
تمثلت فى انخفاض سعر السكن.

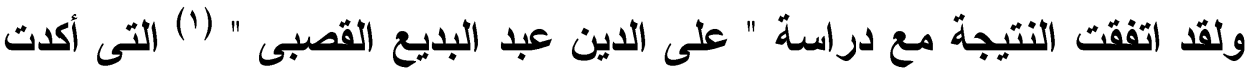

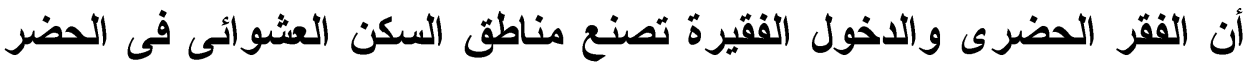

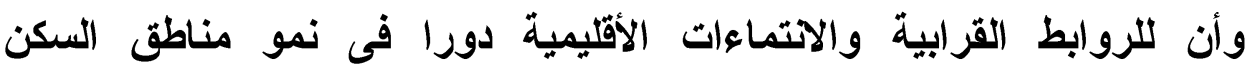

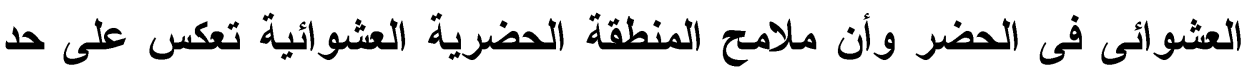

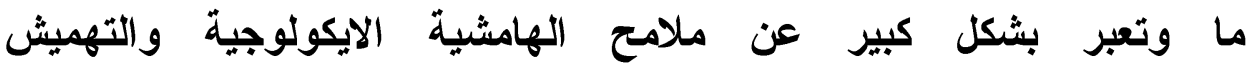

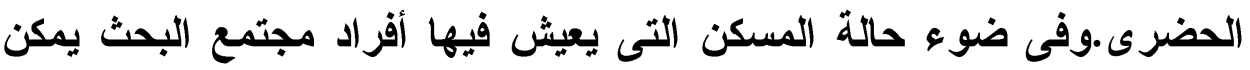
القول بأن هذا المأوى لا يشبع ايه حاجه من الحاجات الآسانيه التى قسمها

$$
\text { ووماكهيل الى:- الى هلى }
$$

أ- حاجات بيولوجيه. ب- حاجات نفسه واجتماعيه.

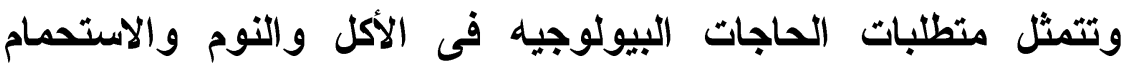

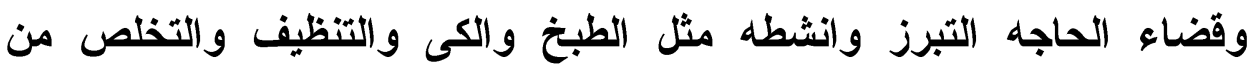

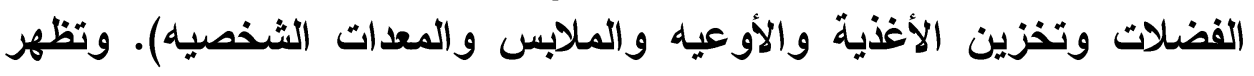

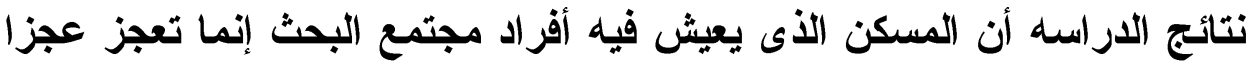

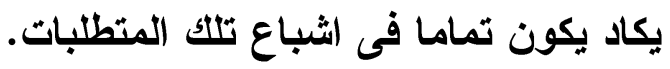

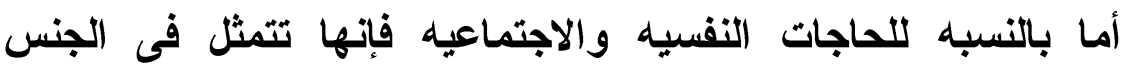

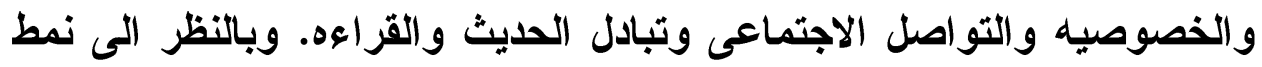

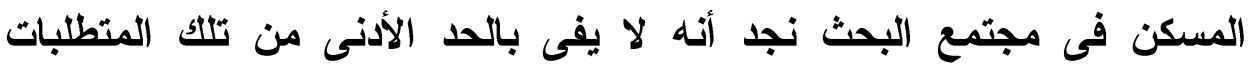

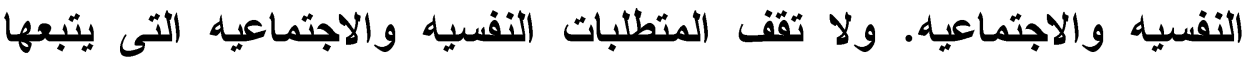

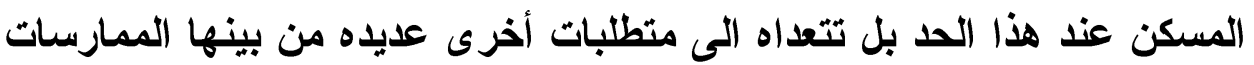

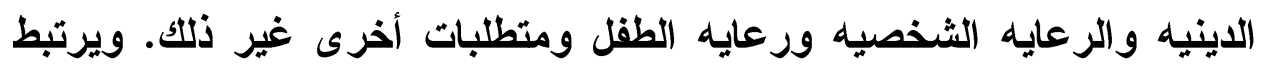

$$
\text { (') (') على الدين عبد البديع القصبى. ديناميات السكن العشو ائى فى منطقة حضرية. مرجع }
$$


باثباع تلك المتطلبات أمورا متعدده جميعها لا تتوافر فى نمط هذا المسكن من هذه المتطلبات.

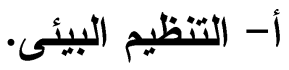
ب- التركيبات والأرضيات الأخليه. ج- التركيبات والأسطح الخارجيه. د- نواح متعلقه بالخدمه الخارجيه وكلها أمور يفتقر اليها المسكن فئه مجتمع الدارسها.

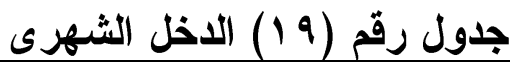

\begin{tabular}{|c|c|c|}
\hline النسبة المئوية & التكر ار & الاستجابة \\
\hline ro & $\Lambda V$ & أقل من · . باجنيه \\
\hline$\varepsilon$. & $1 \cdots$ & من . . \\
\hline Ir & $r$. & من . . .: \\
\hline$\Lambda$ & $r$. & من . . . . \\
\hline-- & -- & من •.9: \\
\hline-- & -- & 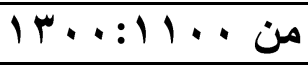 \\
\hline$r$ & $\Lambda$ & من... \\
\hline$\% 1 \ldots$ & ro. & الجملة \\
\hline
\end{tabular}

كثفت نتائج الاراسة أن الاخل الثهرى للمبحوثين يتمثل فى أن نسبة

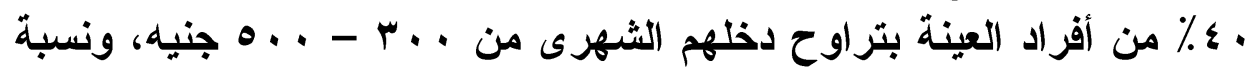

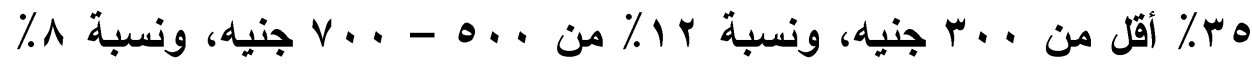

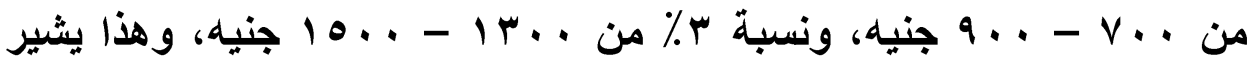

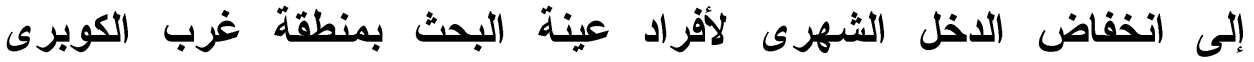
العثوائية، الأمر الأى يؤدى إلى انتشار الفقر بين سكان تلأك المنطقة

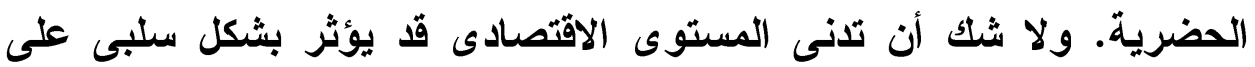

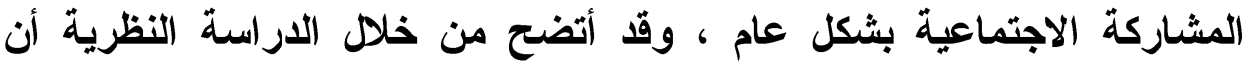

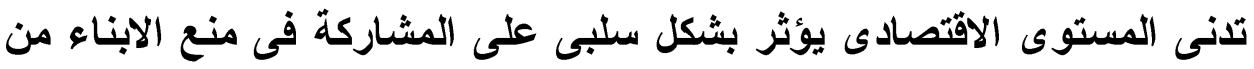

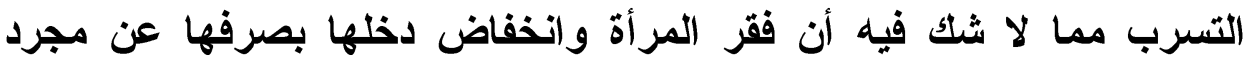

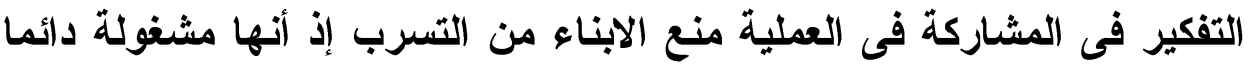

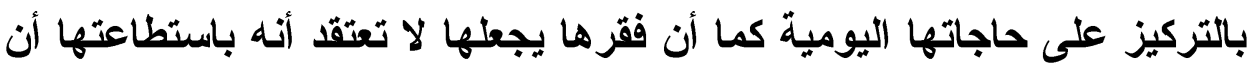
تؤثر فى المجتمع الأى تعيش فيه وبذلك ليس من السهل استمالتها نحو محاولة 


\section{العشوائيات ونمو معدلات الامية والتسرب الدراسى دراسة ميدانية في منطقة عشوائية بمدينة سوهاج}

التأثير فى المجتمع كما أنها تفتقر إلى الموارد الرئيسية للمعرفة والمعلومات وذلك مع ما أوضحته الاراسة سلقاً بشأن الحالة التعليمية لأفراد العينة وأيضاً

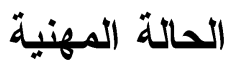

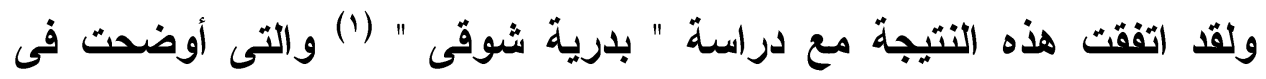

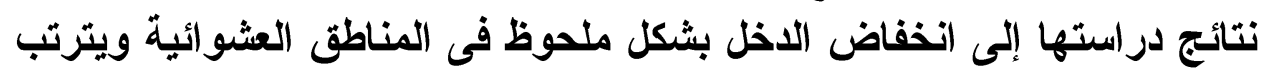

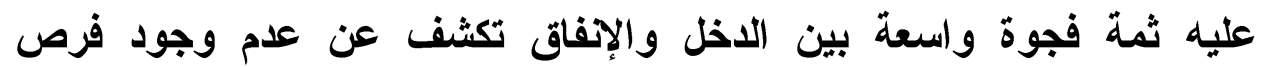
للادخار فى هذه المناطق وبالتالى يجعل السكان دائما في حاجة إلى المس المساعدات

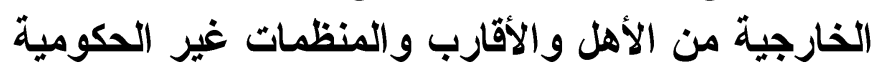

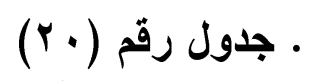

\begin{tabular}{|c|c|c|}
\hline النسبة & التكر ار & الاستجابة \\
\hline $1 \varepsilon$ & ro & مرة في الأسبوع. \\
\hline$r \varepsilon$ & 7. & مرة كل أسبوعين. \\
\hline$r r$ & $\Lambda$. & مرة كل شهر. \\
\hline$r \cdot$ & Vo & كل عيد أضحى \\
\hline$\% 1 \ldots$ & ro. & الجملة \\
\hline
\end{tabular}

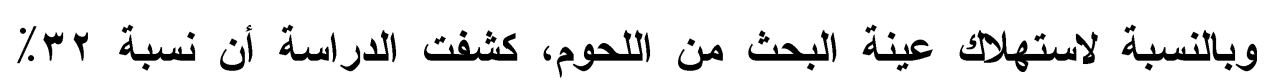

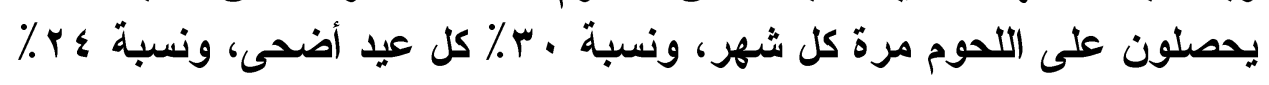

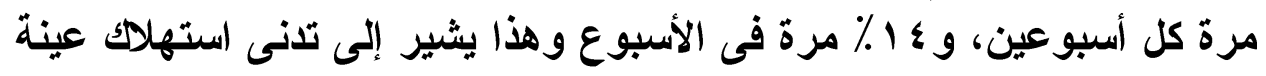

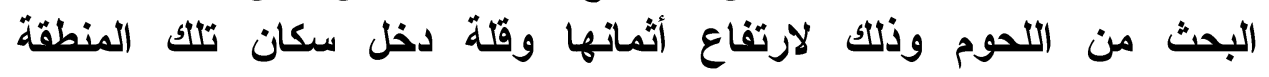
العثوائية.

(' (' بدرية شوقى عبد الو هاب. البنية الاقتصادية لسكان المناطق العشو ائية. مرجع سابق 
مجلة كلية الآداب، جامعة سوهاج، العدد السادس والأربعون، الجزء الأول، يناير 1 I • بم

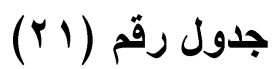

يبين طريقة تصرف المبحوثين حال مرض احد افراد الاسرة

\begin{tabular}{|c|c|c|}
\hline النسبة المئوية & التكر ار & الاستجابة \\
\hline 0 & ir & بروح الصيدلية واشترى له الدواء \\
\hline$r \varepsilon$ & A० & بنعمل له وصفة شعبية في البيت \\
\hline 0 & Ir & بنوديه لعيادة خاصة \\
\hline 11 & $\varepsilon 0$ & بنوديه للمستوصف \\
\hline$r \wedge$ & 90 & بنودية المستشفى \\
\hline$\% 1$. & ro. & اثشياء أخرى تذكر \\
\hline
\end{tabular}

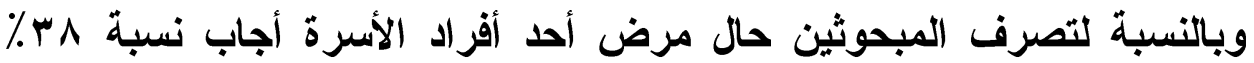

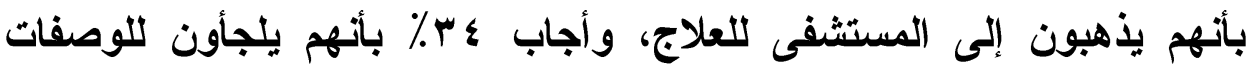

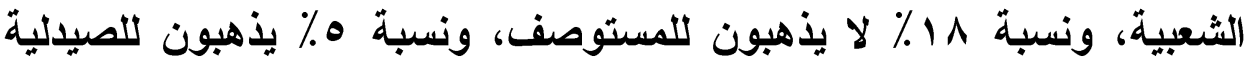

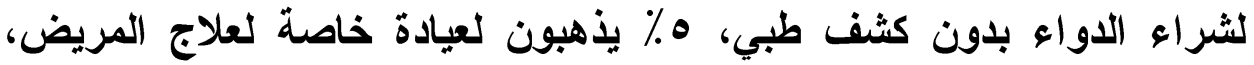

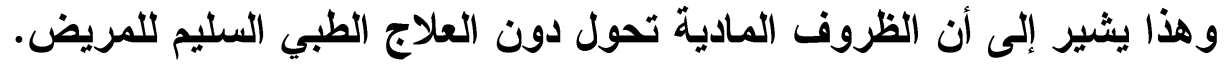

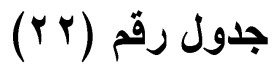

يبين مدى كفاية الاخل لاحتياجات الأسرة

\begin{tabular}{|c|c|c|c|c|c|c|c|c|c|}
\hline الجملة & يكفى & ليكفى & كفح & نعيشّل & والنجِ & بيستر ها & كتيرة & كل برزمة & المتغير \\
\hline Yo. & 7. & 11 & 0 & $\varepsilon 0$ & ro & Ir & Or & $\varepsilon$. & التكر ار \\
\hline$\% 1$. & $Y \varepsilon$ & $\varepsilon$ & $r$ & 11 & 1. & 0 & YI & 17 & المئوية \\
\hline
\end{tabular}

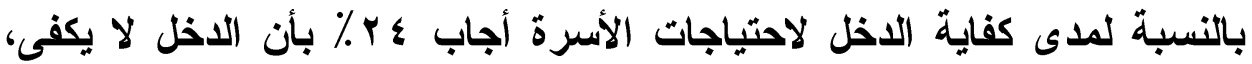

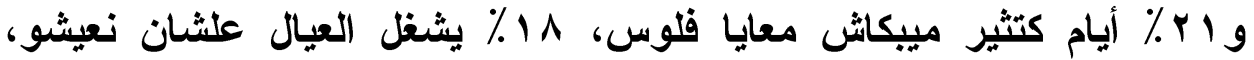

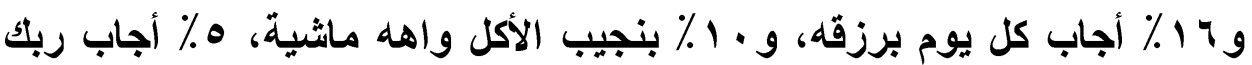

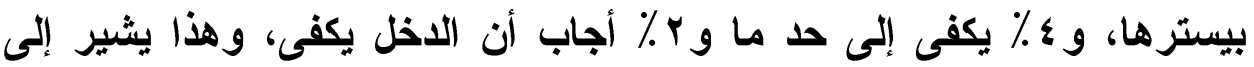


العشوائيات ونمو معدلات الامية والتسرب الدراسى دراسة ميدانية في منطقة عشوائية بمدينة سوهاج

عدم كفاية الاخل لاحتياجات الأسرة الأمر الأى يدفع إلى عمالة الأطفال فى نمالى

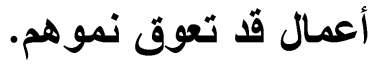

جدول رقم (Yr) حجم الأسرة :

\begin{tabular}{|c|c|c|c|c|c|c|c|c|c|c|}
\hline التكر ار & 1. & 9 & $\Lambda$ & $V$ & 7 & 0 & $\varepsilon$ & $r$ & $r$ & الاسر اد \\
\hline ro. & & & ro & 07 & $7 \varepsilon$ & or & $r \varepsilon$ & $\Lambda$ & & التكر ار \\
\hline$\%$ & & & $1 \varepsilon$ & $\overline{r Y}$ & $r T$ & $Y 1$ & $1 \varepsilon$ & $r$ & & (النس \\
\hline
\end{tabular}

يوضح هذا الجدول حجم الأسرة قد كاتت إجابات المبحوثين كالتالى

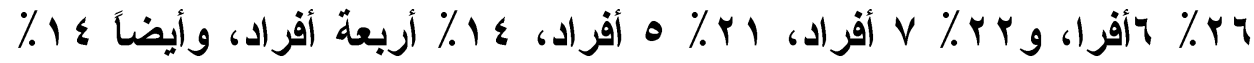

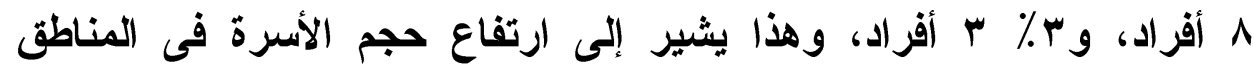

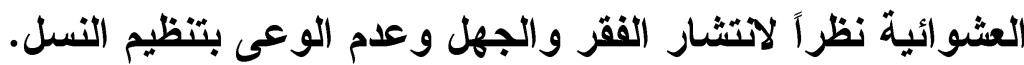

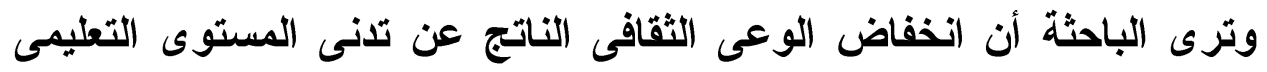

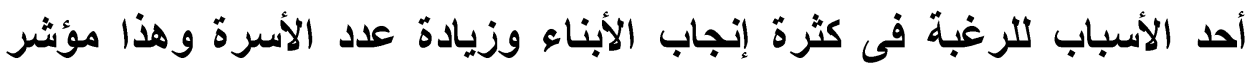

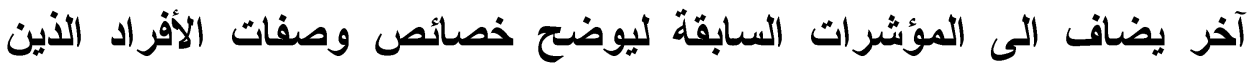
يعيشون فى هذه المناطق.

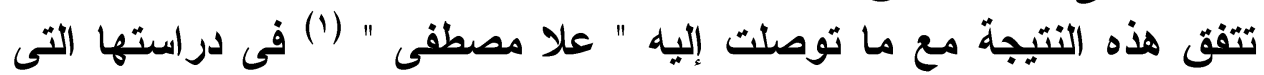

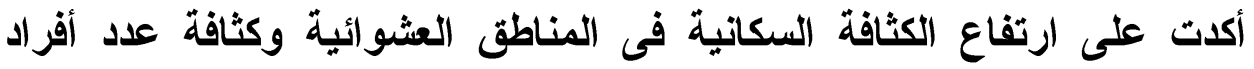

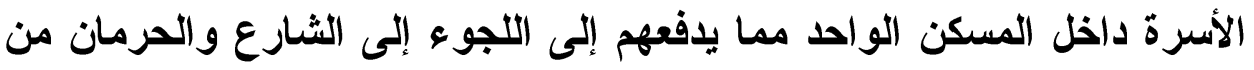

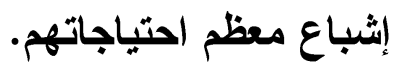
ان الزواج فى هذا المجتمع غير مكلف فكل متطلباته حجرة بها بعض فضاته الأثاث

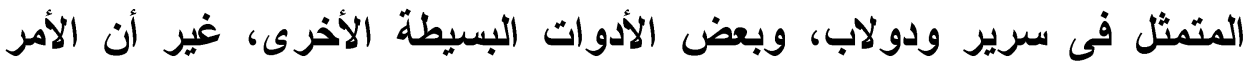

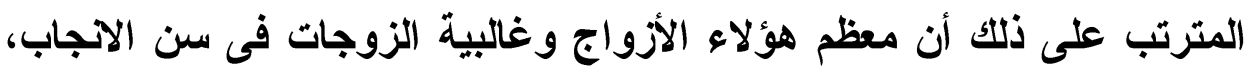

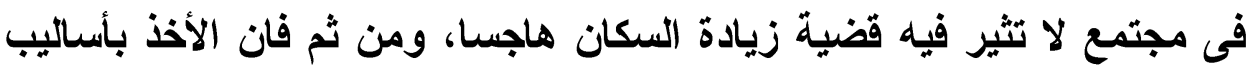

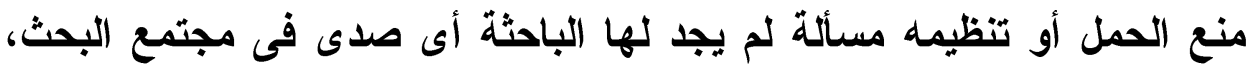

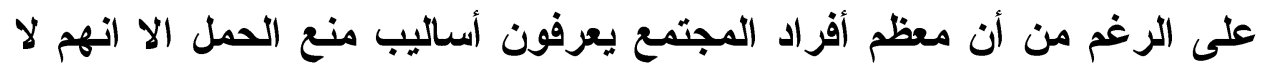

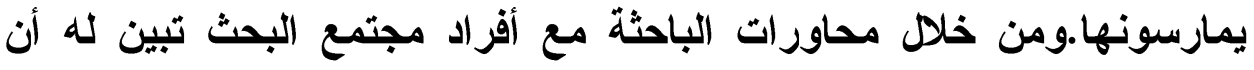

(' (' علا مصطفى و آخرون. الطفل فى المناطق العشو ائية. مرجع سابق. 
هنالك منطقا يبدو غريبا ولكن مجتمع البحث يجد فيه عقلانية ومنطقا، يتمثل وجهة نظرهم فى أن المكان الذى اتسع لمعيشة أربعة يمكن أن يتسع لمعيش لمعيشة

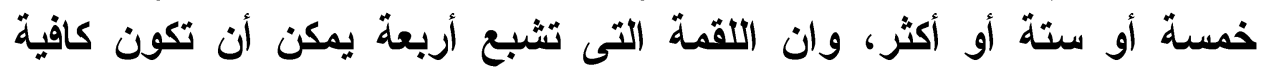

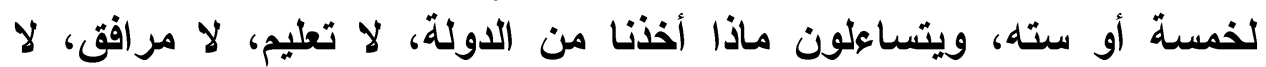

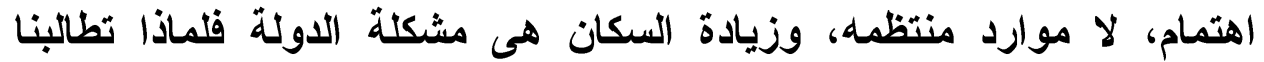

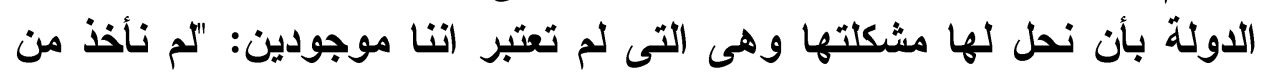

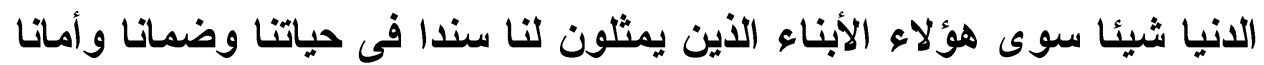
عندما نكبر أو يغدر بنا الزمان" تلك وجهة نظر مجتمع الابناعث فئ فئو اكثر القضايا اهمية.

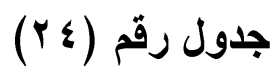

يوضح قيم عمر الأبناء

\begin{tabular}{|c|c|c|}
\hline$\%$ & 5) & عمر الأبناء \\
\hline 9 & $r \varepsilon$ & أقّل من • سنوات \\
\hline ir & r & ه - أقل من - \\
\hline iv & $\varepsilon r$ & . 1 - أقّل من 10 \\
\hline$r$ & $V V$ & 1 - أقل من · r \\
\hline IV & $\varepsilon r$ & 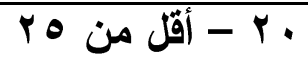 \\
\hline$\Lambda$ & $r$. & 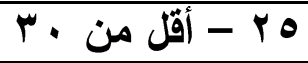 \\
\hline 0 & $1 T$ & r r فأكثر \\
\hline$\%$ & YO. & الجملة \\
\hline
\end{tabular}

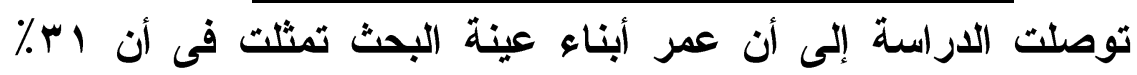

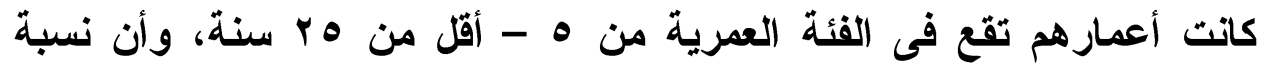

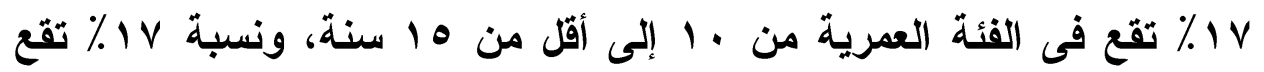

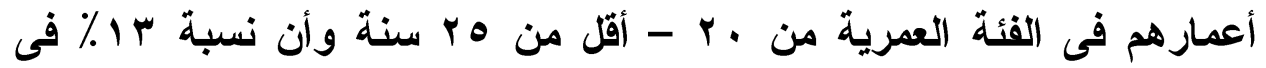

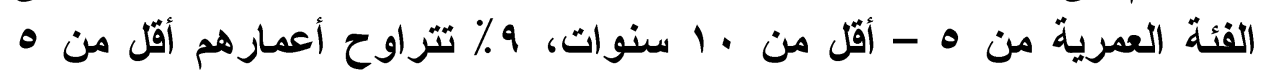

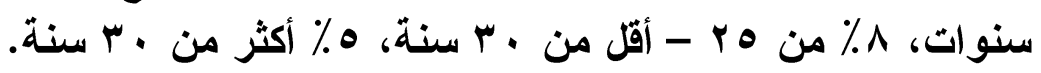


العشوائيات ونمو معدلات الامية والتسرب الدراسى دراسة ميدانية في منطقة عشوائية بمدينة سوهاج

$$
\text { جدول رقم (ro) }
$$

توزيع ابناء المبحوثين حسب الحالة التعليمية

\begin{tabular}{|c|c|c|c|c|c|c|c|}
\hline المجموع & جامعى & ثثانوى & اعدادى & ابتدائية & وترك & لـ لسصل & \\
\hline ro. & - & 11 & 19 & ro & $17 r$ & $r r$ & التكر ار \\
\hline$\% 1 \ldots$ & & $\varepsilon$ & $\wedge$ & $1 \varepsilon$ & 70 & 9 & النسبة \\
\hline
\end{tabular}

بالنسبة لتوزيع أبناء المبحوثين حسب إكماله التعليم، كشفت نتائج الاراسة أن

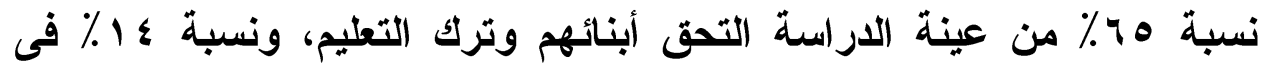

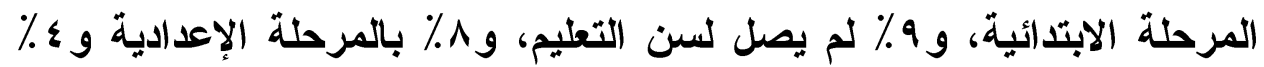

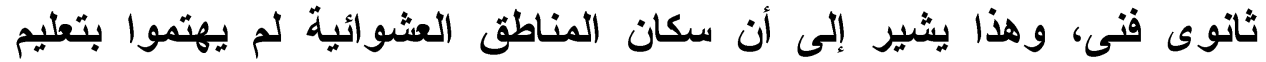
أبنائهم لاتنشار الفقر و والجهل بينهم.

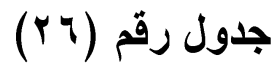

\begin{tabular}{|c|c|c|}
\hline النسبة المئوية & التكر ار & الحالة العملية \\
\hline$V$ & 11 & موظف \\
\hline 9 & Yr & عامل \\
\hline ro & 0. & حرفى \\
\hline 0 & Ir & مشتلغل وحاليا \\
\hline$r v$ & $9 r$ & صبي ميكانيكى \\
\hline YY & $0 \leqslant$ & صبي سمكرى \\
\hline$\% 1 \ldots$ & ro. & المجموع \\
\hline
\end{tabular}

توزيع ابناء المبحوثين حسب الحالة العملية

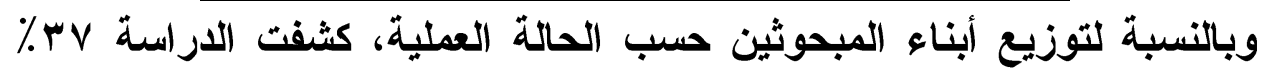

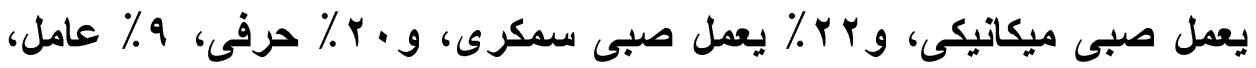

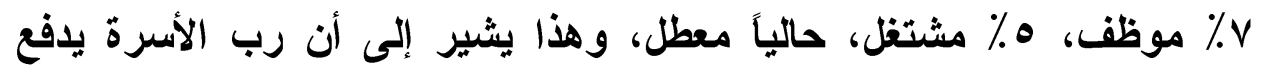

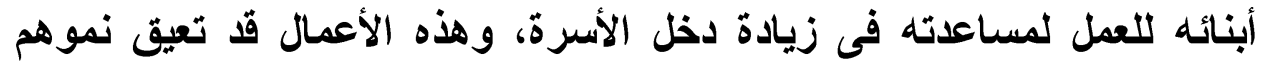


مجلة كلية الآداب، جامعة سوهاج، العدد السادس والأربعون، الجزء الأول، يناير 1 I • Yم

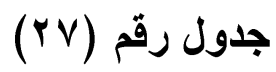

يبين وجود ابناء لم يكملوا تعليمهر

\begin{tabular}{|c|c|c|c|}
\hline المجموع & $y$ & نعم & الاستجابة \\
\hline YO. & $r$. & Tr. & التكر ار \\
\hline$\% 1$. & $\% \wedge$ & $\% 9 r$ & سبة المئوية \\
\hline
\end{tabular}

تثير نتائج الدراسة إلى أن ب 9 \% من أبناء عينة البحث لم يكملوا تعليمهم

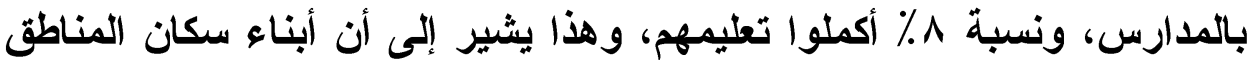

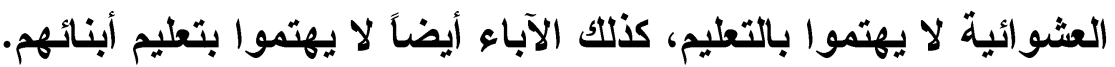

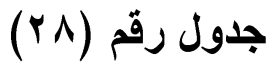

يبين نوع المتسربين من التعليم

\begin{tabular}{|c|c|c|c|}
\hline المجموعة & اناث & ذكور & النوع \\
\hline rr. & 11. & Ir. & التكر ار \\
\hline$\% 1 \ldots$ & $\varepsilon \wedge$ & Or & سبة المئوية \\
\hline
\end{tabular}

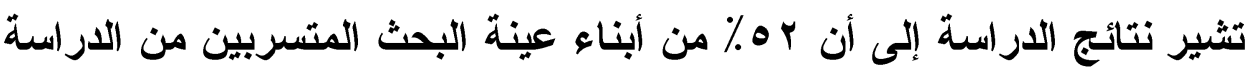

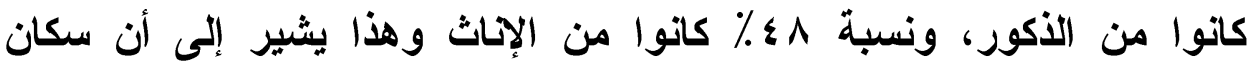

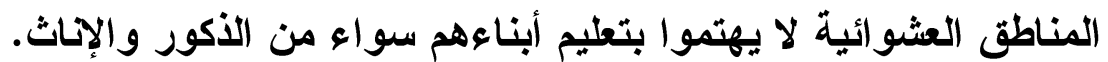

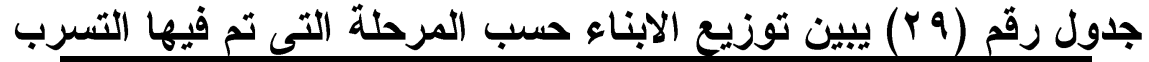

\begin{tabular}{|c|c|c|}
\hline النسبة المئوية & التكر ار & المرحلة \\
\hline $9 r$ & YI & في المرحلة الابتدائية \\
\hline$\Lambda$ & 19 & في المرحلة الاعدادية \\
\hline- & $\overline{-}$ & في المرحلة الثانوية \\
\hline$\% 1 \ldots$ & $r r$. & المجموع \\
\hline
\end{tabular}

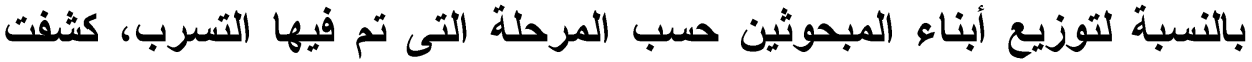

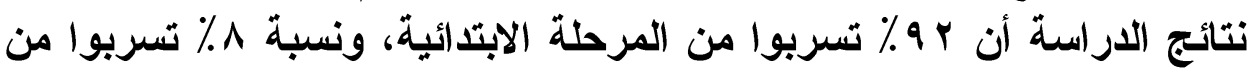

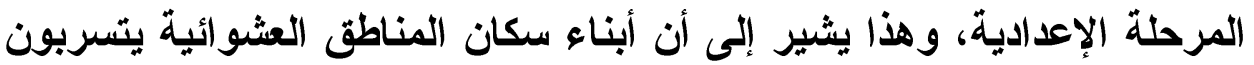
مبكراً وفى المرحلة الأولى من الاعدله التعليم. 
جدول رقم • ب) يبين توزيع أبناء العينة حسب اسباب التسرب

\begin{tabular}{|c|c|c|}
\hline النسبة المئوية & التكر ار & المتغير \\
\hline VY & 177 & لظروف مادية \\
\hline$\varepsilon$ & 9 & ما عندهمش قدرة على التعليم \\
\hline$r$ & $\bullet$ & لأن البنت ملهاش غير بيتها \\
\hline$V$ & 17 & العيل بيهرب ويغيب من المدرسة \\
\hline V & 17 & العيل يشتخل ويساعد في أحسن من التعليم \\
\hline$\Lambda$ & 11 & العيل يتعلم صنعة تنفعه \\
\hline$\% 1 \ldots$ & $r r$. & الجملة \\
\hline
\end{tabular}

وبالنسبة لأسباب تسرب أبناء المبحوثين من التعليم كثفت الاراسة أن نسبة

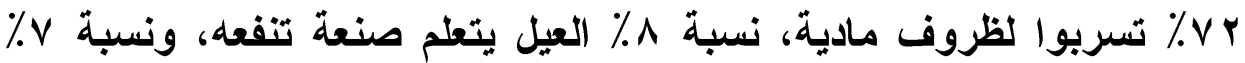

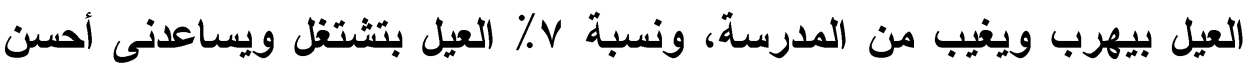

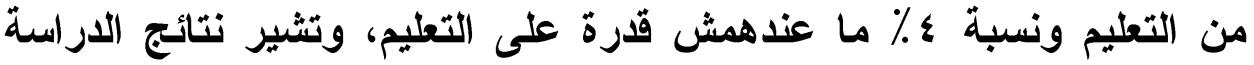

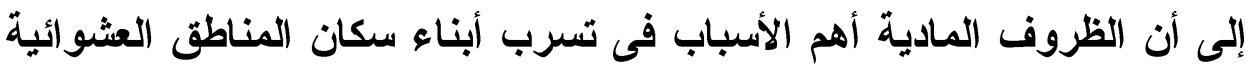

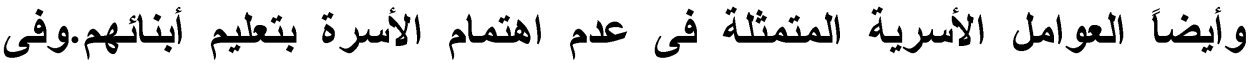

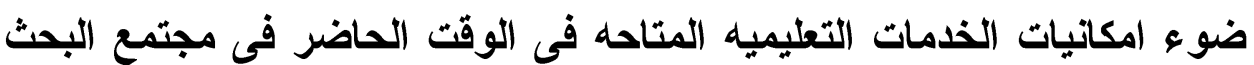
وفى ضوء الظروف الاقتصاديه المتلنيه، وتلنى المستوى الثقافى الأى يسود فئه

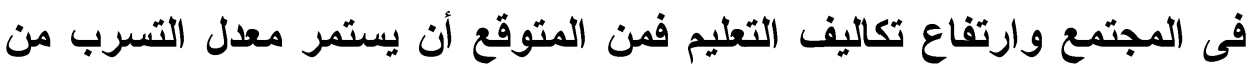

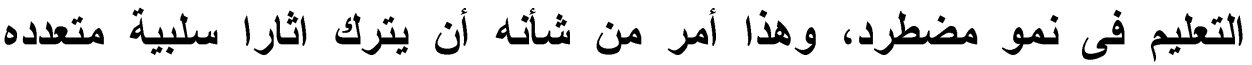

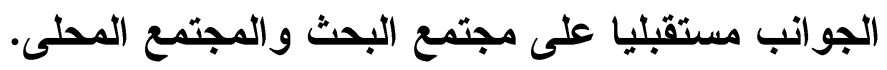
مجمل النتنائم والتوصيات مبريات

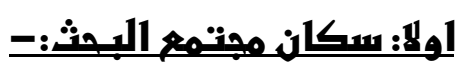

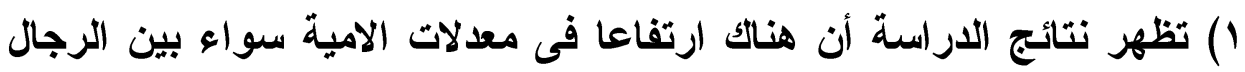

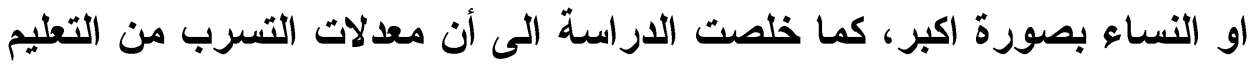

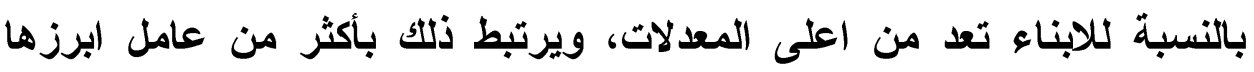

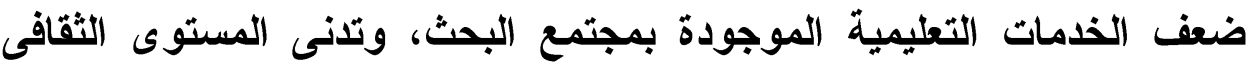

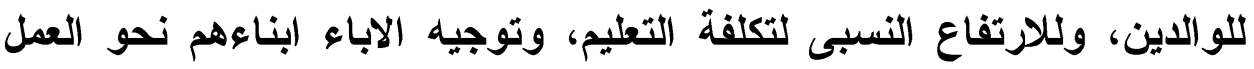

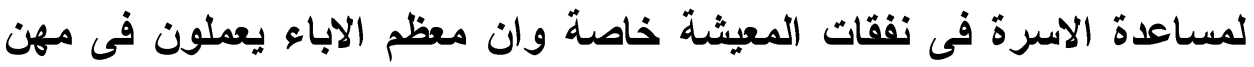

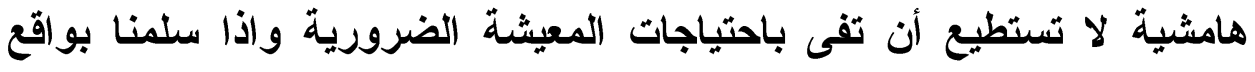
الامر من ناحية امية الاباء والامهات فإن الخطر يكمن في التسليم بترك معدلات التهات 
التسرب تتزايد، الامر الأى يتركب عليه نتائج سيئة، فان هؤلاء الصبية

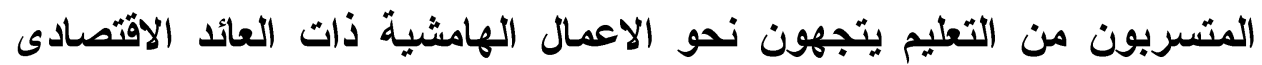

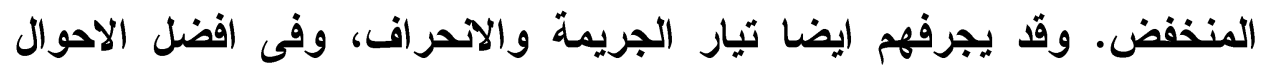

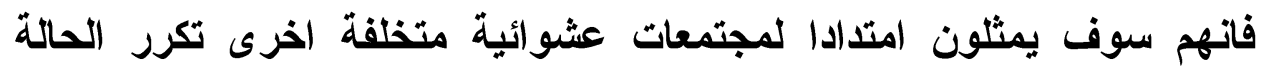
السيئة التى تعيثها المجتمعات العثو ائية المعاصرة.

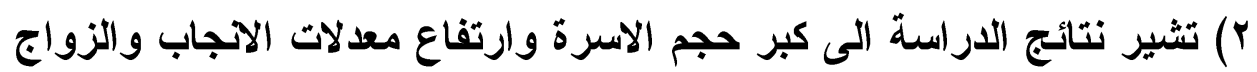

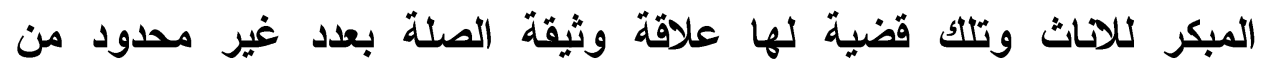

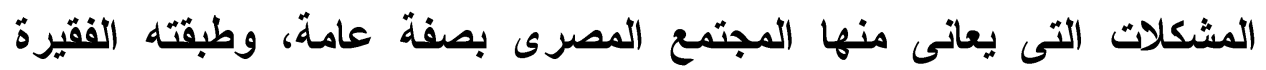
بصفة خاصة، وقد تناولت الدراسة بعض القضائة القصايا المرتبطة بالنتيجة السابقة

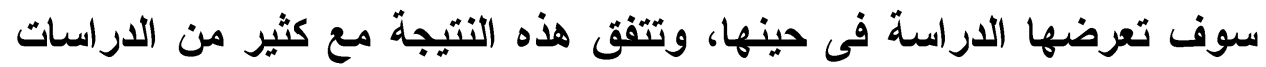

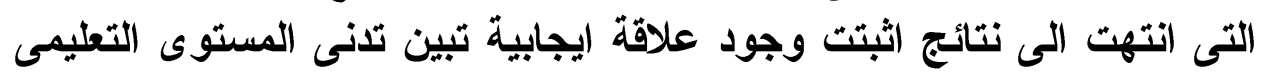
والاقتصادى وكبر حجم الاسرة التئر

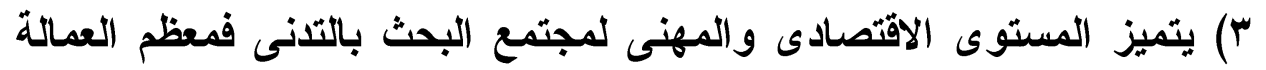

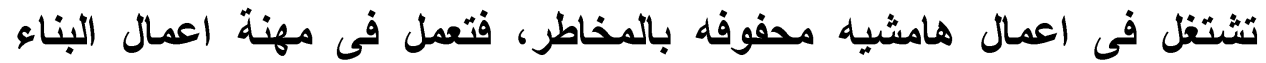

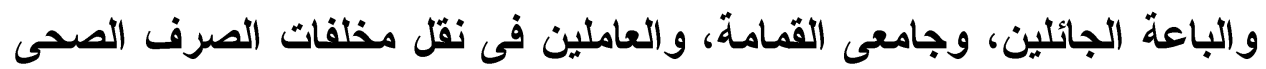

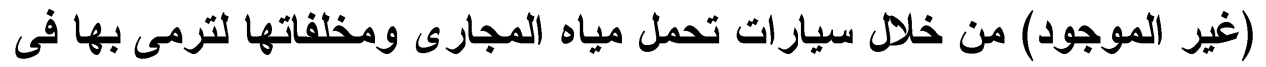

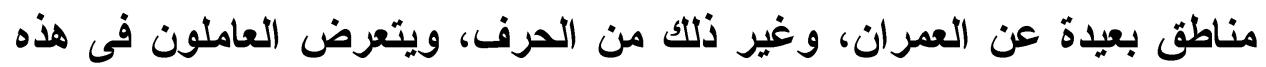

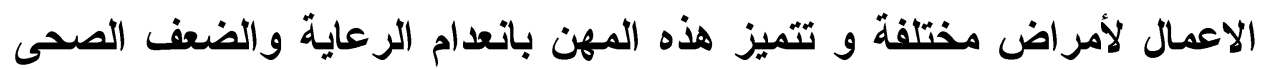

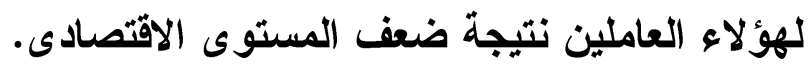

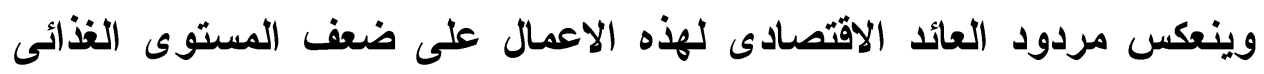

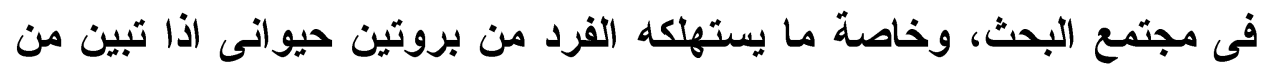

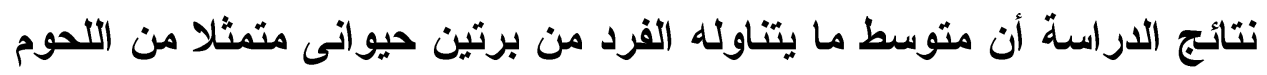

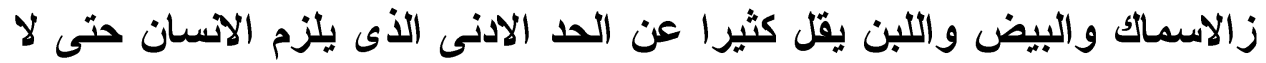

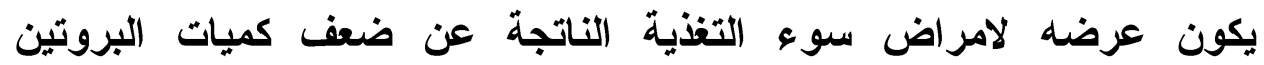

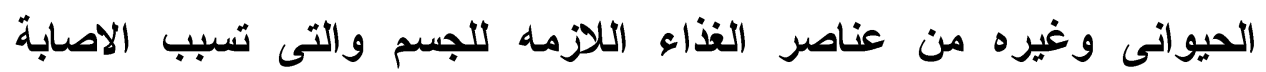
بأمراض الضوى وغيره من وعمى الاطفال، والبرى برى و والبلاجرا و الاسقربوط وغيره 


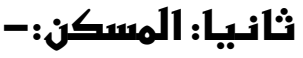

يتميز المسكن فى منطقة البحث بانعدام وجود أى جانب من الجوانب التى فيك المبك

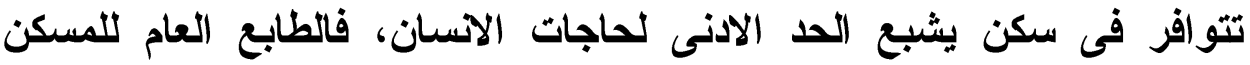
عبارة عن حجرة للنوم الجماعى وتخزين واعداد وتناول الطعام، واستحمام

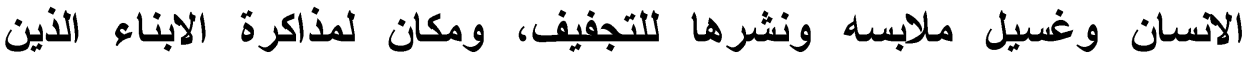

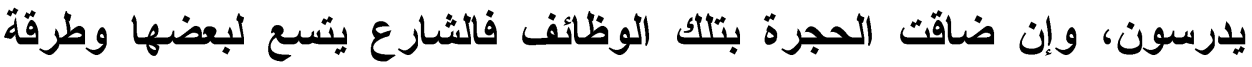

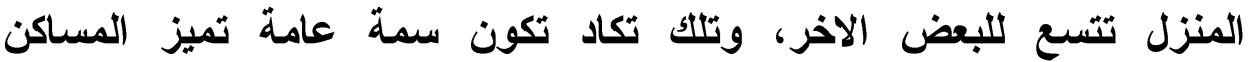

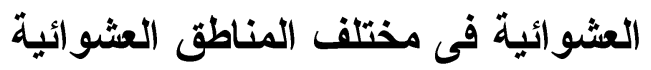

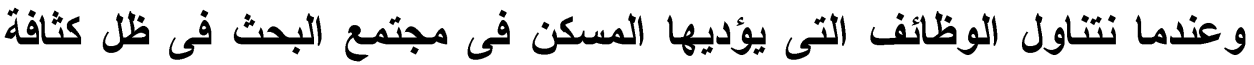

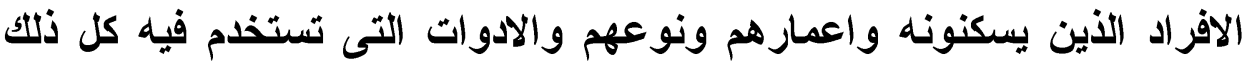
فى ظل ثقافة تقليديه تحكمها الى حد ما قيم دينيه فانتا سوف نكتشف وأن أن كثيرا

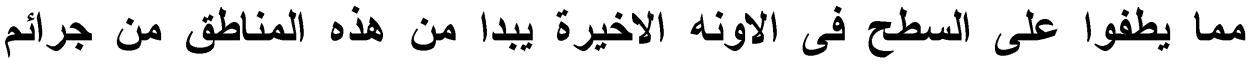

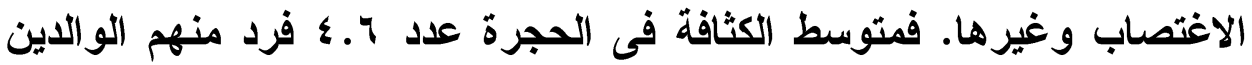

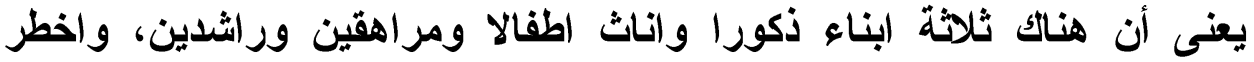
القضايا النفسيه والاجتماعية المترتبة على نوم الابوين مع ابنائهما الاطفال

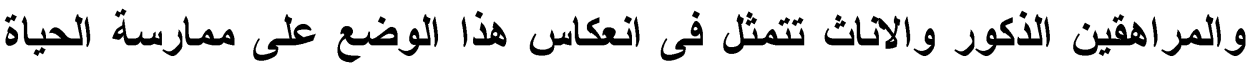

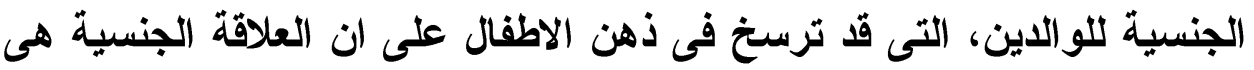

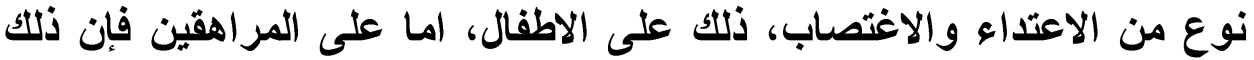

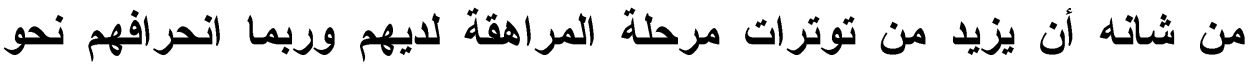

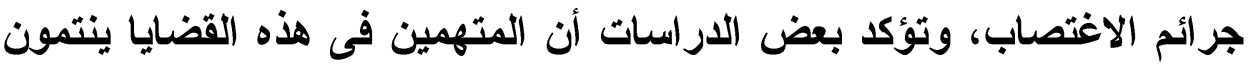

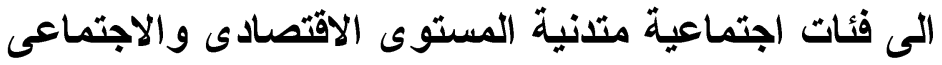

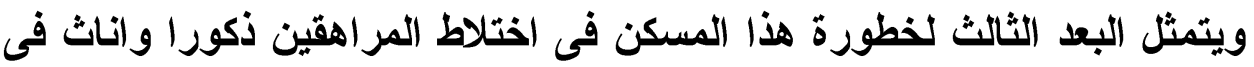

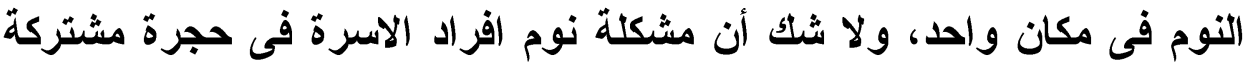

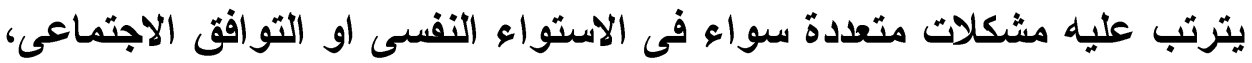

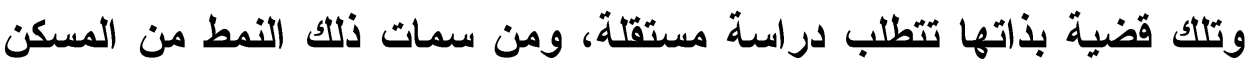

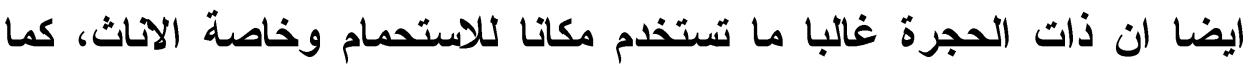

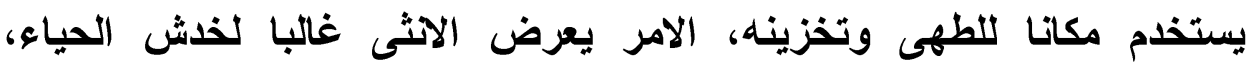

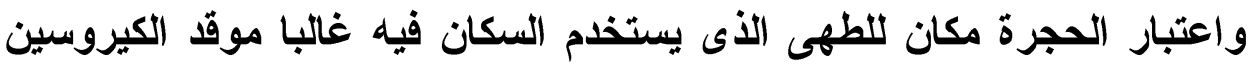
انما يمثل خطورة دائمة باثتعال النار فى محتويات الحجرة، كما لأن تخزين 
الطعام بالحجرة يعرضه للفساد والتسمم وكلها مخاطر دائمة يتعرض لها الأين

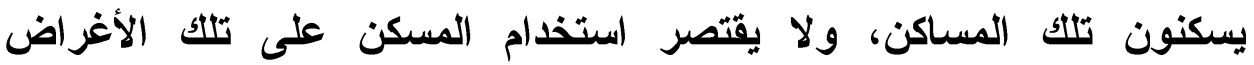

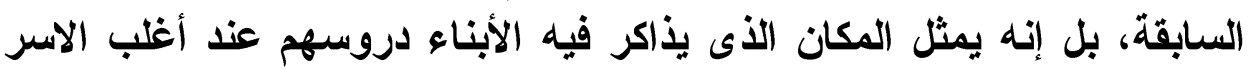

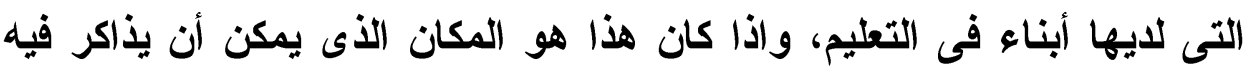

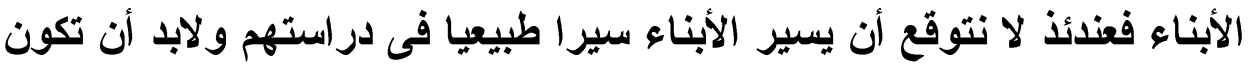

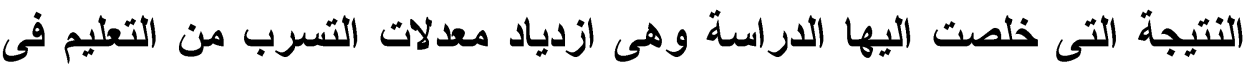

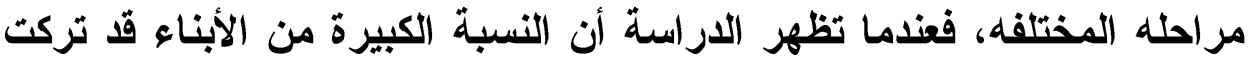

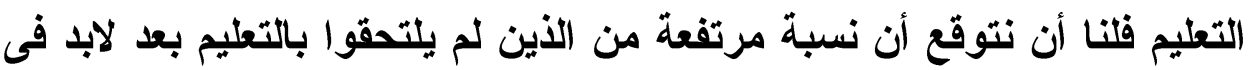

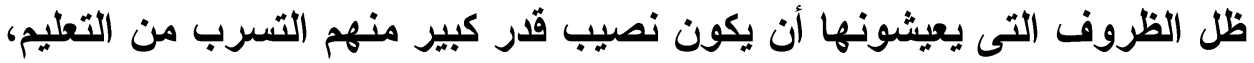

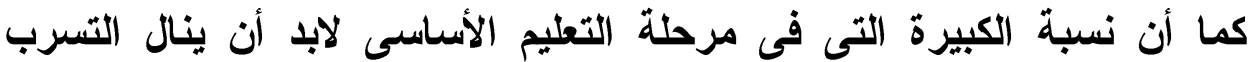

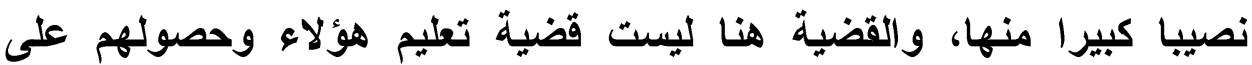

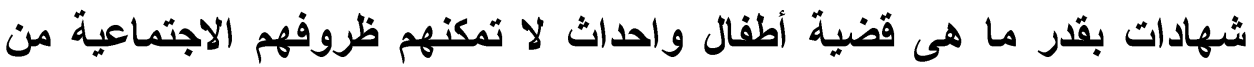

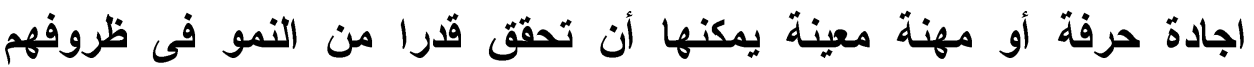

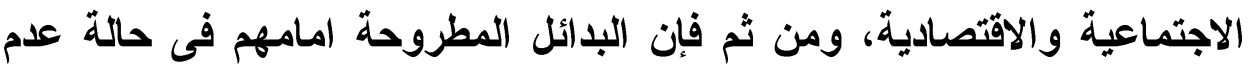

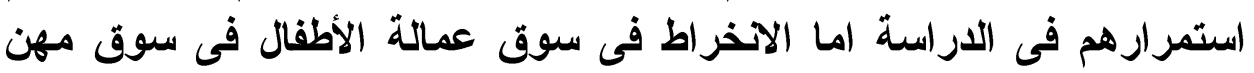
الصناعة بكل ما يحتويه هذا السوق من ضياع لحقوق الطقولة والأطفال.

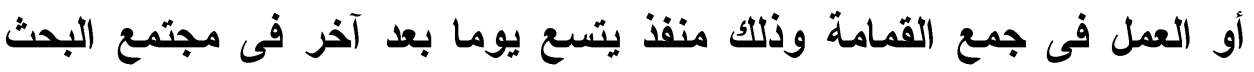

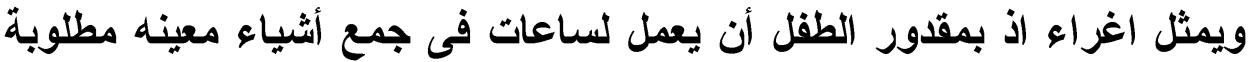

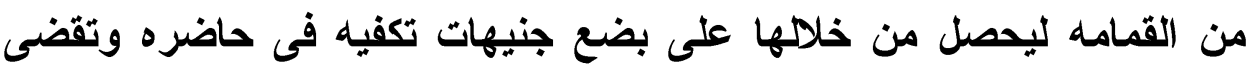

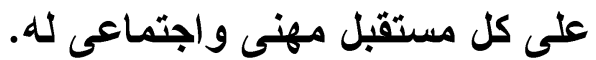

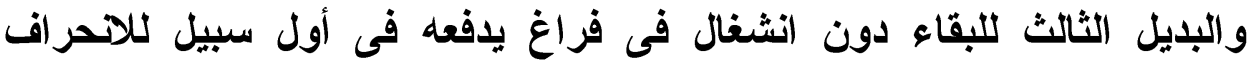

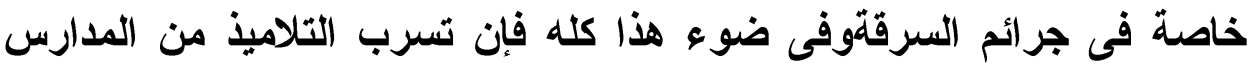

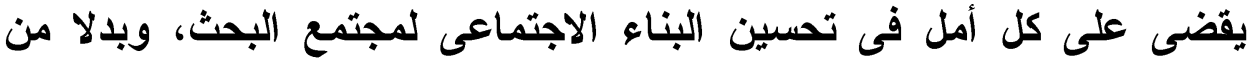

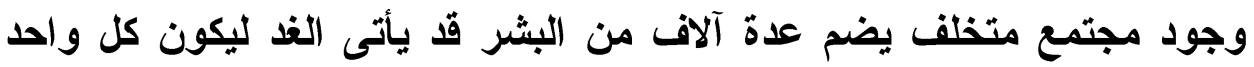

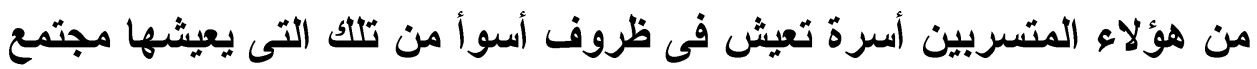
البحث ذاته.

\section{توصيات الدراسةة:}

فى ضوء مستخلصات الاراسة فإن التوصيات تتجه نحو قضيتين: الأولى، قضية التسرب الاراسى، ولقد أفرزت الدراسة مجموعة من العوامل المرتبطة 


\section{العشوائيات ونمو معدلات الامية والتسرب الدراسى دراسة ميدانية في منطقة عشوائية بمدينة سوهاج}

بقضية التسرب الاراسى والتى يبرز دور المدرس والبرامج الدراسية وأيكولوجية المدرسة كعوامل مرتبطة بالتسرب الاراسى، وفى هذا الشأن فإن

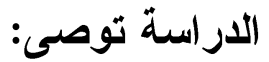
أن يمثل مدرس المرحلة الأبتدائية خصوصية فى إختياره وتقييمه، وأن ترجمة

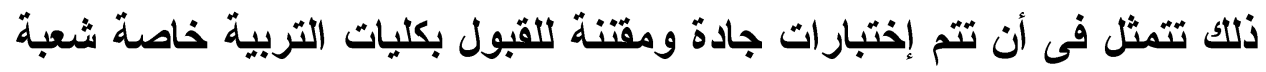

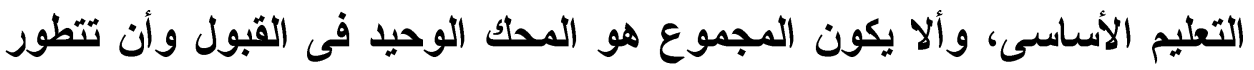
أساليب الإختبار ات المطبقة حاليا حتى نخرج من الإنى الحالة الثكلية التى هى عليها

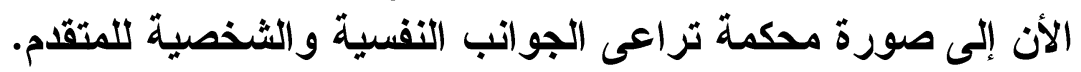

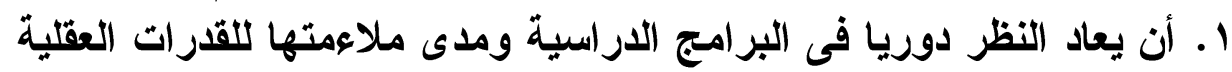

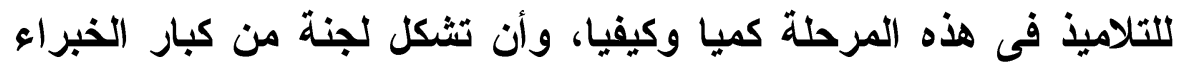

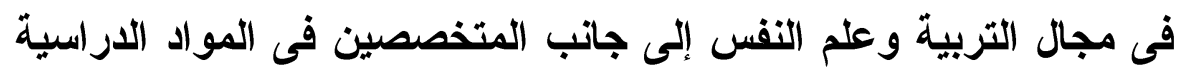

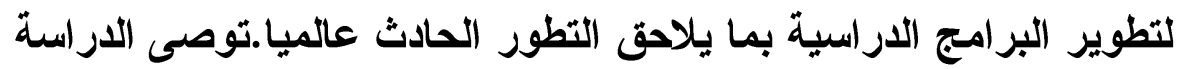

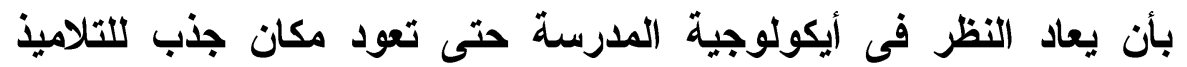

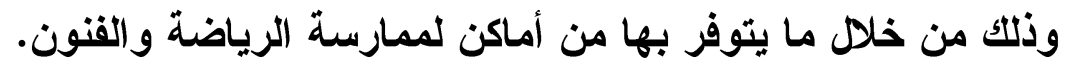

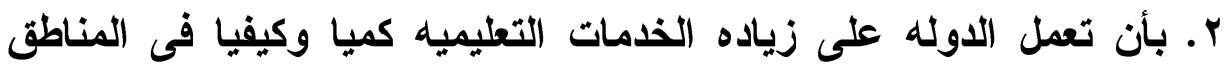

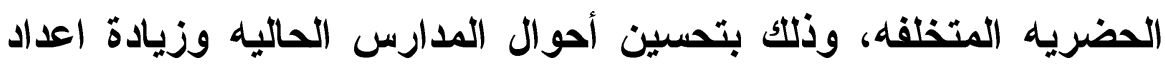
المدارس حتى يمكن أن تستوعب الاعداد المتسربه التى تنضم سنويا

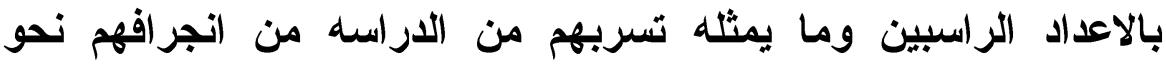
الانحر اف أو سوق العمل الهامشيه.

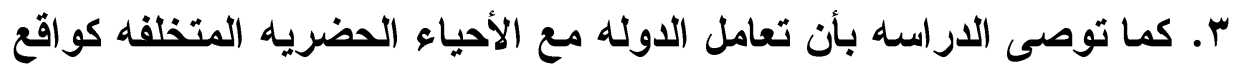

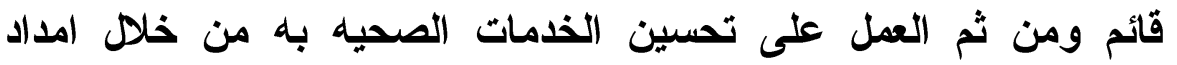

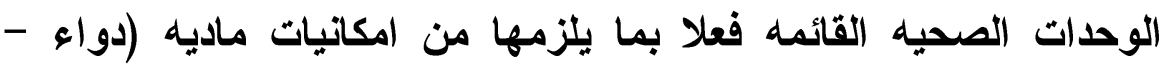
أدوات طبيه) وكوادر فنيه (الأطباء ومساعديهم).

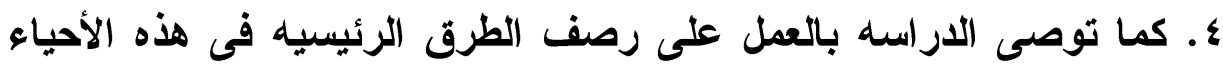

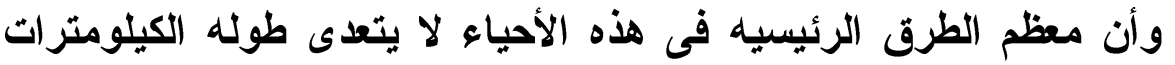

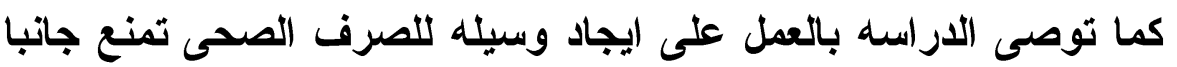

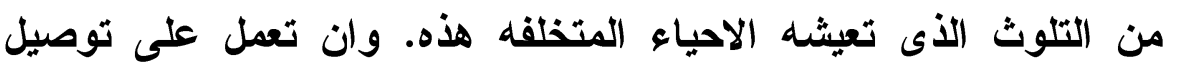
المياه النقيه للشرب سواء كاتت فى حنفيات عامه أو داخل المنازل. 


\section{المراجr}

ا. أحمد بلر. أصول البحث العلمى ومناهجه ، الكويت ، وكالة المطبوعات ،

$$
\text { .V • 19VV }
$$

r. أحمد محمد النوري - السكن العشوائي بمدينة الخرطوم المشاكل

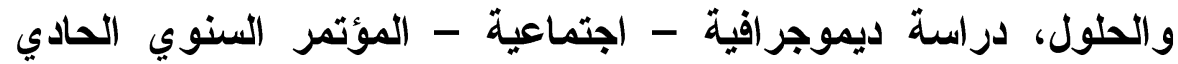

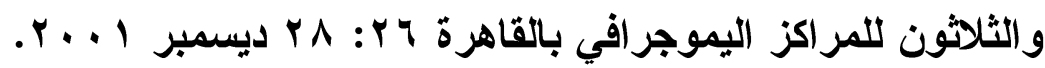

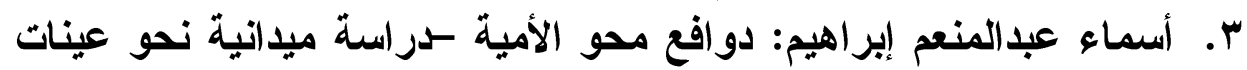
من الأميين، مؤتمر الامية في الوطن العربى،التحدى والمواجهة التهيلة :الاسرة

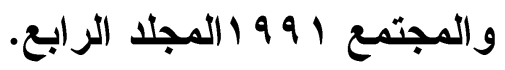

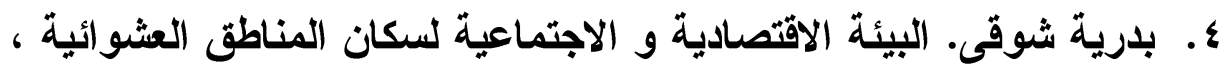

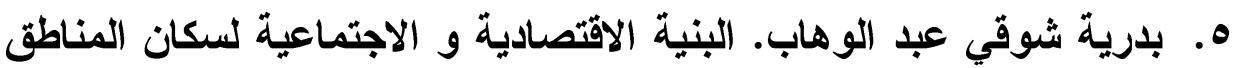
العشو ائيةة،

7. الجهاز المركزى للتعبئة العامة والاحصاء،الجهاز المركزى للتعبئة العامة

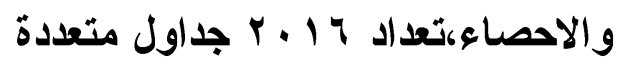

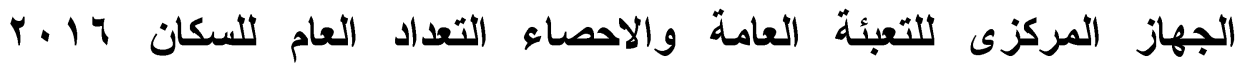

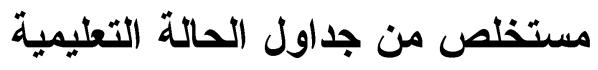

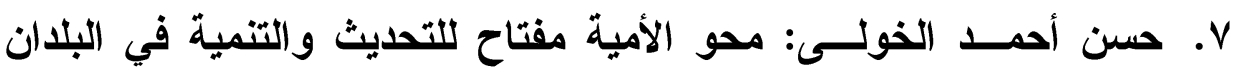
النامية، المجلد الثاني

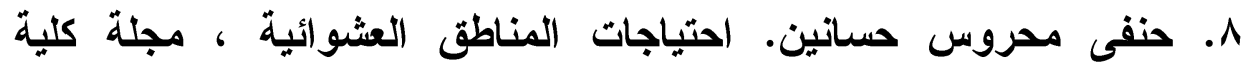
الاداب، جامعة اسيوط ، العدد الاول ،

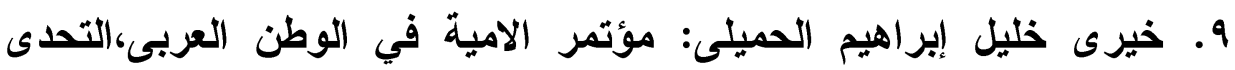

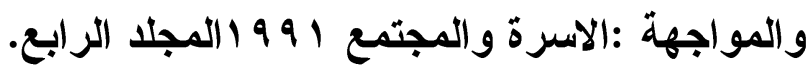

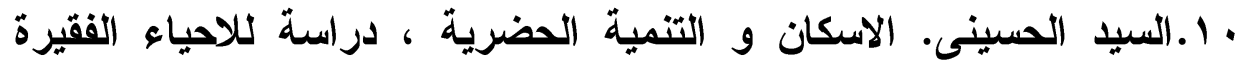
بمدينة القاهرة ، مكتبة غريب الاسيكان ، 1991 ،

1 ا.السيا عوض حنفي: الأحياء الحضرية المتخلفة أنماط ومشكلات سكانها -

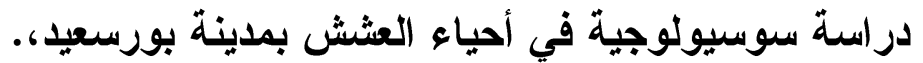

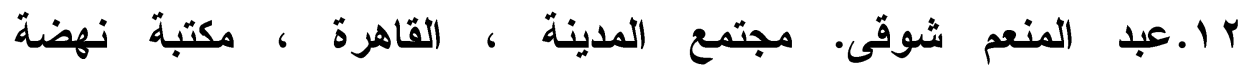

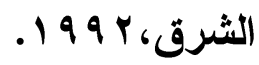

I ا.عبد الهادى الجوهرى. أصول علم الاجتماع ، مرجع سابق ، 99 ل . 


\section{العشوائيات ونمو معدلات الامية والتسرب الدراسى دراسة ميدانية في منطقة عشوائية بمدينة سوهاج}

ع ا.عبد الهادي الجوهري. العثوائيات ، الاسباب و الابعاد ، المؤتمر السنوي السادس عشر ، العشوائيات.

ه اـعدلي أمين أحمد ابو عقيل. المشاركة السياسية لسكان المناطق العثوائية

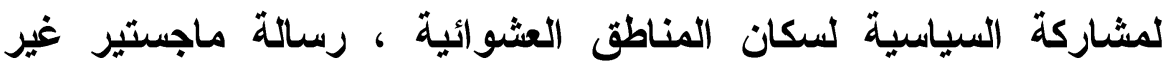

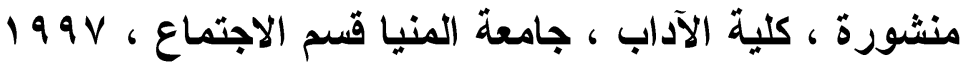

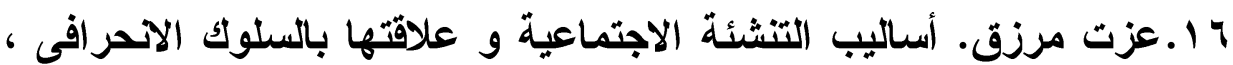

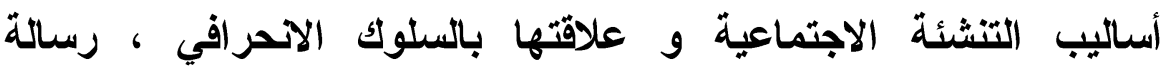
ماجستير غير منشورة ، جامعة أسيوط ، كلية الآداب، قسم الاجتماع. 6r... 1

IV عيد السيد فرح - المهنة والعلاقات الاجتماعية بين سكان العشوائيات

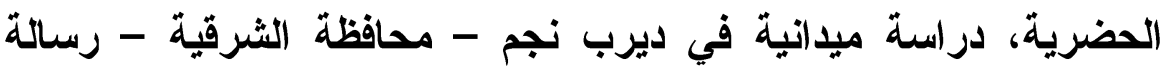

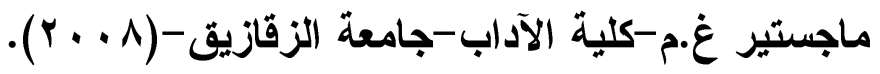

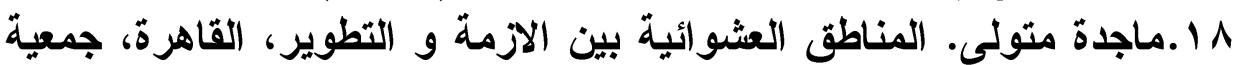

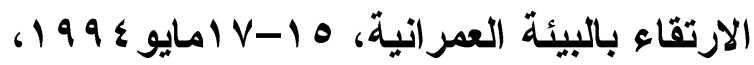

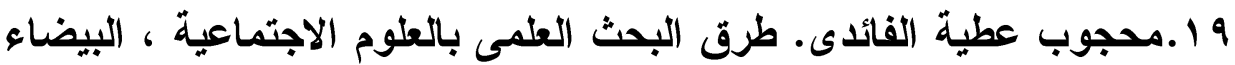

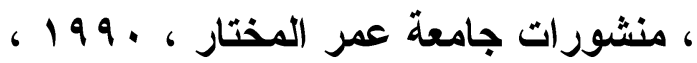

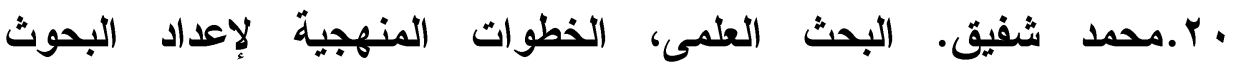

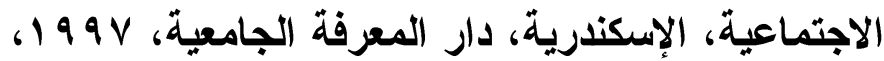

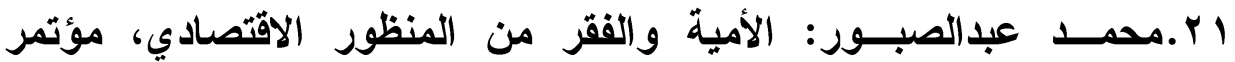

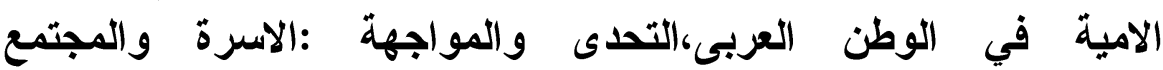
199 الالمجلا الرابع المجلد الثالث.

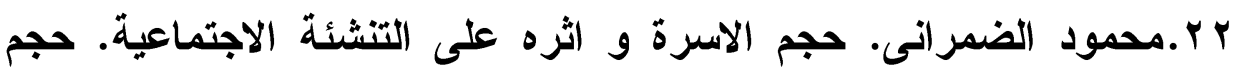

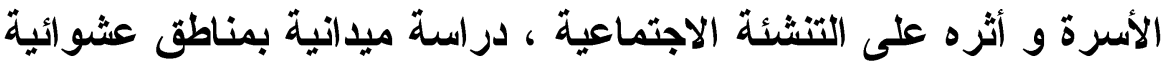

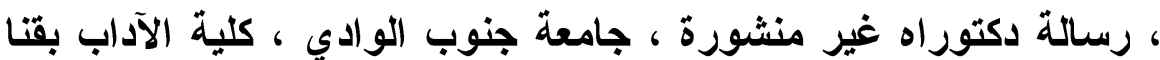

rr..محمود الكردي و آخرون. العشوائيات في المجتمع المصري، المركز القومي للبحوث الاجتماعية و الجنائية. برنامج العشودئي ولئيات في المجتمع

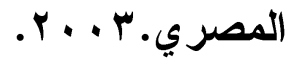


ع ب.محمود عبد الله الحبيس - العوامل المؤثرة في مستوى الخصوبة

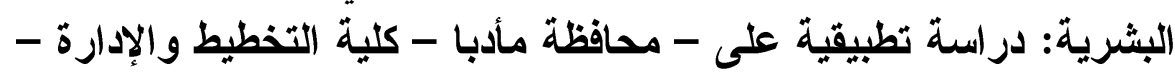

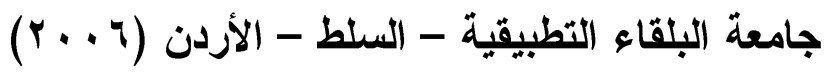

ه . محمود محمد جاد- التضخم الحضري وسكنى المقابر في مدينة القاهرة -

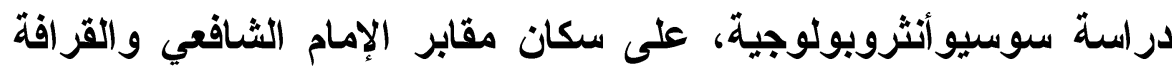

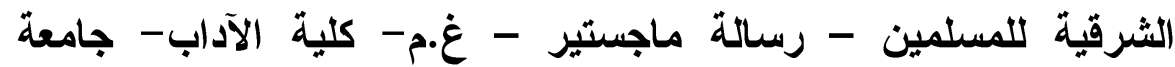

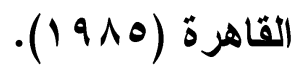

צ..ممدوح الولي. سكان العشش و و العشوائيات ، الخريطة الإسكانية للمحافظات،

VV.rV

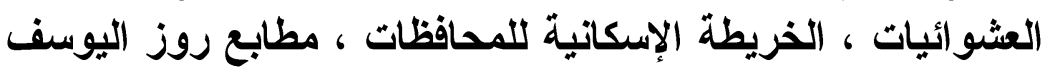

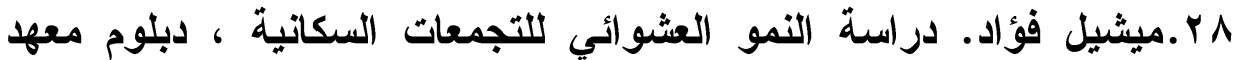

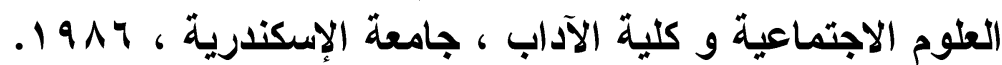

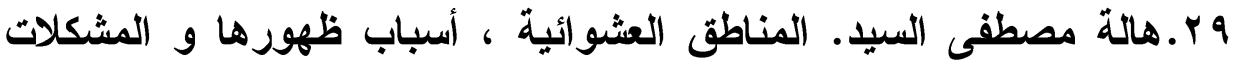

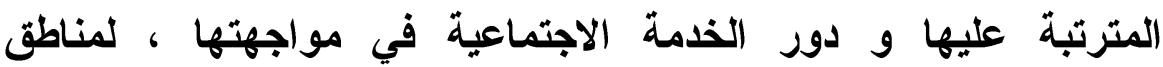

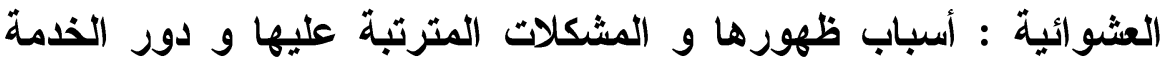

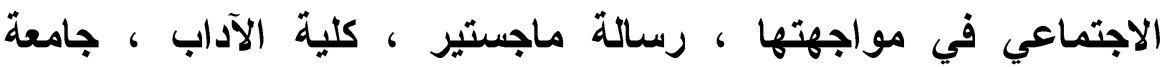

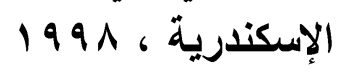

• •.همام بلراوى زيدان ودسوقي حسين عبدالخليل: إدارة عمليات التخطيط

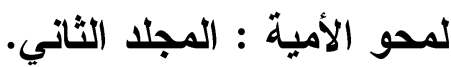

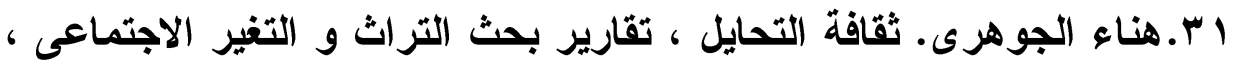

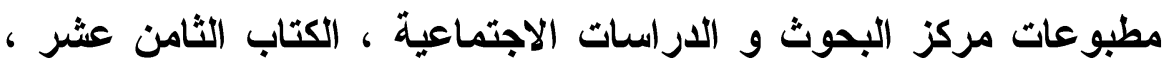

$$
\text { . r. . . }
$$

r r.وفاءعلى زكى. مدى فاعلية برنامج التدخل المهني في تعديل السلولك

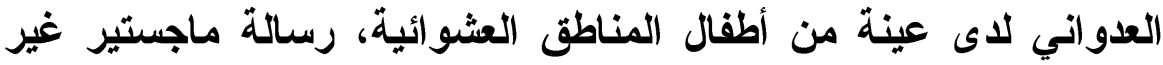

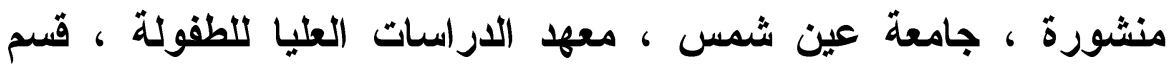

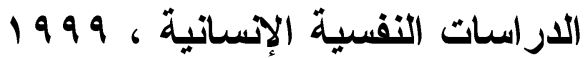

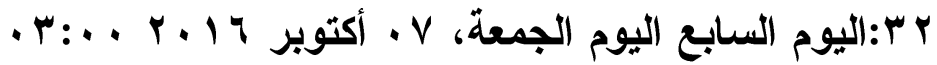

